\title{
MEMÓRIA HISTÓRICA DA FACULDADE DE SAÚDE PÚBLICA DA UNIVERSIDADE DE SÃO PAULO - 1918 - 1945
}

\author{
Nelly Martins Ferreira Candeias*
}

\section{INTRODUÇÃO}

Há alguns anos, manifestou-se na Faculdade de Saúde Pública um "esprit de corps" que se traduziu no empenho de preservar e estudar sua memória histórica. Reuniu-se assim em uma única sala, hoje denominada de Pró-Memória, cartas, recortes de jornais, fotografias, relatórios, manuscritos pessoais, projetos de leis com comentários, livros, boletins e revistas, objetos e geraçōes de instrumentos, antes dispersos, que se considerou de inestimável valor para a história desta Instituição. Com o tempo, outros interessados, professores aposentados ou membros de diferentes estabelecimentos, passaram a contribuir com pertences e esforços para ampliar o acervo de documentos desta Faculda. de.

Em comemoração ao Cinqüentenário da Universidade de São Paulo, decidiu-se publicar um artigo, de carater histórico com o objetivo de dar conhecimento destes achados e, mais importante, preservar fatos, comentários, idéias e aspirações neles contidos. Começamos portanto a ordená-los conforme assuntos e cronologia, valendo-nos também do material para este fim cedido pela Sra. D. Evangelina Rodrigues de Paula Souza, esposa do fundador e primeiro Diretor desta Escola.

Ao reexaminarmos a documentação as$\operatorname{sim}$ organizada, percebemos a existência, mais ou menos velada, de um núcleo comum: a disposição de transformar o Laboratório da Cadeira de Higiene da Faculdade de Medicina e Cirurgia em uma unidade autônoma de ensino de Saúde Pública, visando ao preparo de sanitaristas e contribuindo, assim, para o aperfeiçoamento técnico do trabalho sanitário em nosso país.

Os elementos que oferecemos ao leitor, para que fique com informaçðes que julga. mos indispensáveis a uma leitura séria, provêm do rigoroso e paciente exame das fontes e de discussões que tivemos com os que viveram e acompanharam de perto a evolução deste processo - professores aposentados que fizeram parte da Congregação e do Conselho Técnico Administrativo desta Escola.

Acreditamos ter fornecido as indicações mais necessárias a quem se interesse por alguma. Reconhecemos, contudo, que fossem os pormenores dos eventos, aqui discutidos, estudados isoladamente, transformar-se-iam eles próprios em amplos tratados históricos. Foi esta a razão que nos levou a apresentá-los sob forma às vezes bastante resumida.

\section{A FORMAÇÃO DE SANITARISTAS}

Em 1914, o Conselho Geral da Educação, nos Estados Unidos, propôs às autoridades do país a criação de Centros para preparo do pessoal destinado ao ensino, pesquisa e prestação de serviços em Saúde Pública. Formou-se, por isso, um grupo de trabalho com representantes das áreas da Educação, Medicina e Saúde Pública que, após cuidadosa análise, decidiu recomendar a criação, em âmbito universitário, de Faculdades de Higiene e Saúde Pública naquele país. De acordo com esses especialistas, pretendia-se

* Do Departamento de Prática de Saúde Pública da Faculdade de Saúde Pública da Universidade de São Paulo - Av. Dr. Arnaldo, 715 - Sáo Paulo, SP - Brasil. 
CANDEIAS, N. M. F. Memória histórica da Faculdade de Saúde Pública da Universidade de São Paulo 1918 - 1945. Rev. Saúde puibl., S. Paulo, 18(n? esp.): 2-60, 1984.

que estas mantivessem estreita relação com Faculdades de Medicina, permanecendo, contudo, como entidades separadas, cujo núcleo deveria constituir um Instituto de Higie$\mathrm{ne}^{5}$.

Deve-se à Fundação Rockefeller o crédito de ter sido a instituição internacional que mais influiu, a partir de 1916 e durante longo período de tempo, não só para elevação dos padrões de formação do pessoal de saúde pública, como também para o avanço e aperfeiçoamento das técnicas do trabalho sanitá. rio ${ }^{1}$.

Coube a William Henry Welch, famoso bacteriologista da época, e a Wickliffe Rose, então Presidente da Junta Internacional de Saúde da Fundação Rockefeller, estudar os critérios que deveriam estruturar as Escolas de Saúde Pública nos Estados Unidos e em outros países. Welch e Rose passaram a analisar as instituições então existentes. Dois países apresentavam na época significativo desenvolvimento nesse campo. Na Alemanha praticamente todas as Faculdades contavam já com um Departamento ou Instituto de Higiene. $O$ primeiro fôra fundado por Pettenkoffer em Munich, em 1865. Com importantes programas de investigação, particularmente no que dizia respeito a aspectos ligados à disseminação de doenças infecciosas, cabia-lhe preparar profissionais com só. lidos conhecimentos em Ciências Biomédicas. Também na Grã-Bretanha se desenvolviam programas de treinamento para administradores na área de Saúde Pública, desta. cando-se o país por essa peculiaridade.

Ao elaborar o relatório que lhes tinha sido solicitado, Welch e Rose passaram a discorrer sobre as vantagens inerentes à integração dos dois sistemas, aspecto essencial, segundo eles, para o desenvolvimento de instituiçбes de alta qualidade. Ao enfatizar a importância do ensino e da pesquisa na área da Saúde Pública, passaram a definir Higiene como Ciência da Saúde ou, complementando, "o corpo global de conhecimentos e sua aplicação no que diz respeito à promoção e melhoria da saúde dos indivíduos e de comunidades, assim como prevenção de doenças". Referiam-se a uma "Faculdade Universitária de Saúde Pública" como o local onde se deveriam encontrar, para trabalhar juntos, docentes de formação multidisciplinar e alunos das áreas de Ciências Biológicas, Físicas, Sociais e Comportamentais ${ }^{5}$.

Deve-se a Welch e Rose, assim, o estabelecimento dos princípios gerais que deveriam servir de guia à Fundação Rockefeller para a criação e estruturação de Escolas de Saúde Pública nos Estados Unidos e em outros países do mundo.

Os princípios por eles apresentados foram os seguintes $^{(1)}$ :

1. atribuição de um mesmo peso tanto aos aspectos científicos da Higiene como à tarefa prática de preparar candidatos para ocupar cargos de Saúde Pública;

2. previsão de cursos teóricos e práticos para sanitaristas, em regime de tempo integral, em serviços de saúde a nível federal, estadual e local, segundo necessidades locais; reconhecimento de que o aspecto prático do preparo do pessoal não deveria obscurecer a concepção da Higiene como Ciência e Arte, cujo campo se considerava mais amplo do que sua aplicação à administração da Saúde Pública - deste modo, a função principal da instituição deveria prender-se ao desenvolvimento do espírito de investigação e ao processo do conhecimento;

3. acesso aos recursos necessários ao ensino de alunos de medicina e de médicos diplomados;

4. coordenação entre a Faculdade de Saúde Pública e Escolas ou Departamentos de Ciências Sociais - tendo em vista os numerosos pontos de contato entre problemas sociais e problemas de saúde pública e considerando-se o impacto dos fatores sócio-econômicos, sugeria-se que os alu-

(1) Chope, H. D., Princípios fundamentais de Orientação da Fundação Rockefeller em Relação a Escolas de Saúde Pública, Arquivo da Pró-Memória, FSP/USP. 
CANDEIAS, N. M. F. Memória histórica da Faculdade de Saúde Pública da Universidade đe São Paulo 1918 - 1945. Rev. Saude puibl., S. Paulo, 18(n? esp.): 2-60, 1984.

nos de Ciências Sociais usufruissem das facilidades oferecidas pelo Instituto de Higiene e que os alunos de Higiene se familiarizassem, por sua vez, com Ciências Sociais e Serviço Social;

6. individualidade própria - embora intimamente relacionada com a Universidade e a Faculdade de Medicina, a Faculdade de Saúde Pública deveria manter bases próprias, resguardando e acentuando sua própria individualidade como instituiçăo à parte, devotada exclusivamente a aspectos científicos e práticos da higiene e contando, além disso, com acesso a edifício próprio e a corpo próprio de docentes, assim como com meios necessários para o desenvolvimento do ensino e pesquisa.

\section{A PRIMEIRA ESCOLA}

Baseada neste estudo, passou a Fundação Rockefeller a proporcionar assistência financeira a diversos países com o intuito de criar e auxiliar escolas e institutos dessa natureza. A primeira instituição a receber auxilio financeiro para a consecução desse objetivo foi a Universidade de Johns Hopkins em Baltimore, em 1916, e a segunda a Faculdade de Medicina e Cirurgia em São Paulo, em $1917^{(1)}$.

As verbas então concedidas pela Fundação passaram a subvencionar Universidades nos Estados Unidos e Secretarias de Saúde na Europa. A esse respeito comentava Geraldo Horácio de Paula Souza, fundador da Faculdade de Saúde Pública e seu primeiro Diretor $^{(2)}$ :

"nos Estados Unidos a escolha de Universidades em vez de Secretarias de Saude justifica-se náo apenas pelo maior grau de cultura dessas instituições, como também pelo seu maior afastamento dos interesses de politica partidária. Na Europa isto nāo se faz sen- tir da mesma forma, visto que a estabilidade das Secretarias de Saúde e a não intromissāo indébita da politica partidária representam garantia suficiente para o andamento harmonioso dos serviços a seu cargo".

Ao examinar, portanto, as condiçōes das universidades americanas de maior prestígio, a Fundação Rockefeller, em seu empenho de criar a primeira Escola de Higiene e Saúde Pública do mundo, voltou-se para a Universidade de Johns Hopkins, em Baltimore, não só por suas instalaçð̃es, como também pelos altos ideais que então transpare. ciam em sua Faculdade de Medicina. Além disso, ali se encontravam dois eminentes professores a quem se decidira entregar a experiência da primeira direção: William George Welch, como Diretor, e William H. Howell, como Vice-Diretor.

Frequientador dos laboratórios de Koch e Pasteur e-figura de renome internacional, William Henry Welch (1850-1934) fôra discípulo de Max Pettenkoffer (1818-1901), médico e higienista alemão. A este devia-se- lhe o mérito de ter sido o primeiro a subme. ter a Higiene à análise laboratorial, dando início assim a trabalhos inovadores sobre nutriçăo, vestuário, ventilação, áqua e esgo$\operatorname{tos}^{12}{ }^{16}$. Sob influência do mestre, Welch foi capaz de introduzir a Medicina Experimental nos Estados Unidos. William Henry Howell, o Vice-Diretor, era, na época, notável professor de Fisiologia.

Ao contrário do que iria acontecer concomitantemente em Sร̃.o Paulo que a essa altura ainda náo contava com sua Universidade, não se tratava apenas de introduzir a Cadeira ou Departamento de Higiene na Faculdade de Medicina de Baltimore. Mais do que isto, pretendia-se ali a criação de uma escola individualizada de Higiene, integrada à Universidade onde se destacava Escola Médica que, famosa por sua excelência, não oferecia ainda a Cadeira de Higiene para seus alu-

(1) Chope, H.D., Prinćpíps Fundamentais da Orientação da Fundação Rockefeller em Relação a Escolas de Saúde Pública. Arquivo Pró-Memória, FSP/USP.

(2) Documento sem data, Arquivo da Pró-Memória, FSP/USP. 
CANDEIAS, N. M. F. Memória histórica da Faculdade de Saúde Pública da Universidade de São Paulo 1918 - 1945. Rev. Saúde públ., S. Paulo, 18(no esp.): 2-60, 1984.

nos. Por essa razão estes recebiam apenas algumas noções dessa matéria durante o programa da Cadeira de Bacteriologia. Muito se deve a Welch por seu estudo a respeito de como deveria ser uma Faculdade de Higiene e Saúde Pública. Não admira e é justo que Rosen, em seu famoso livro ${ }^{12}$, o refira como uma das "Figuras Memoráveis da História da Saúde Pública".

\section{A CADEIRA DE HIGIENE DA ESCOLA DE MEDICINA}

A Faculdade de Medicina e Cirurgia de São Paulo foi estabelecida pela Lei no 1357 de 19 de dezembro de 1912, assinada pelo Presidente de Estado Francisco de Paula Rodrigues Alves e pelo Secretário do Interior Altino Arantes. Seu regulamento foi baixado pelo Decreto no 2344 de 31 de janeiro de 1913, tendo a lei entrado imediatamente em vigor ${ }^{2}{ }^{14}$.

A administração e a cadeira de História Natural foram instaladas na Escola de Comércio Alvares Penteado e as cadeiras de Física e Química na Escola Politécnica, cujo Diretor era então Antonio Francisco de Pau. la Souza ${ }^{(1)}$, pai de Geraldo Horácio. Em 1914 arrendou-se prédio na Rua Brigadeiro Tobias, 42 ; em 1915 por este não comportar a instalação de novas cadeiras, foi arrendado o prédio nQ 1 da mesma rua ${ }^{14}$.

Cumpre aqui registrar dois fatos de valor histórico a respeito dos primeiros contatos da Fundação Rockefeller com o Brasil no ano de 1916. O primeiro prende-se à visita feita por Missão Médica, enviada por aquela fundação, composta por Richard M. Pearce, - da Universidade da Pennsylvannia, pelo Major Bailey Ashford, do Corpo Médico do Exército dos Estados Unidos, e por John A. Ferrell, ${ }^{(2)}$ da referida instituição. Consta do Relatório da Fundação Rockefeller, para o ano de 1916, que de tal forma ficara a Comissão impressionada com os resultados dos trabalhos realizados no Brasil contra a febre amarela, "one of the most brilliant achievements of modern sanitary administration", que se considerou interessante, para ambas as partes, estabelecer contato com o país que tanto havia contribuido para o bem-estar do hemisfério. Reconhecia-se portanto, nesse contato, inestimável valor para as relaçōes médicas e culturais das duas Américas ${ }^{1}$.

Dessa visita, segundo fato a relatar, resultaram entendimentos que, em dezembro desse mesmo ano, aproximariam a Escola de Medicina e Cirurgia de Sáo Paulo à Funda. ção Rockefeller ${ }^{1,14}$ : a Faculdade de Medicina foi representada pelo seu primeiro $\mathrm{Di}$ retor, Arnaldo Vieira de Carvalho (1867. 1920), e a Fundação por Pearce, Diretor de Educação Médica. Foi quando se discutiu o provimento das cadeiras de Higiene e Anatomia e Histologia Patológica daquela Escola. Ao chegar a São Paulo, em Fevereiro de 1917, Pearce, com a anuência de Wickliffe Rose, Diretor da Junta Internacional de Saúde, apresentou sugestóes para acordo referente à criação de um Instituto de Higiene, anexo à Faculdade de Medicina e Cirurgia, assinado este no dia 9 de fevereiro de $1918^{14}$. Firmara o Governo do Estado de São Paulo termo de ajuste com a Junta Internacional de Saúde (International Health Board) para organizar o Departamento de Higiene anexo à Faculdade de Medicina (3). Assinado, quando Altino Arantes ocupava a presidên. cia de São Paulo e Oscar Rodrigues Alves a Secretaria do Interior, deveria o contrato vigorar por um período de cinco anos. Obrigava-se o Governo a fornecer, para a organização e instalação desse Departamento, um prédio adaptado ao seu funcionamento, durante o referido período, com acomodaçoes necessárias para ensino e pesquisa e, além

(1) Antonio Francisco de Paula Souza (1843-1917), pai de Geraldo Horácio, fundou a Escola Politécnica no ano de 1894, tendo sido seu Diretor até o fim de sua vida.

(2) Primeiro indivíduo formado pela Escola de Higiene e Saúde Pública, de Baltimore, em 1919.

(3) O Jornal, 12 de dezembro de 1926: Uma grande e moderna Escola de Saúde Pública. 
CANDEIAS, N. M. F. Memória histórica da Faculdade de Saúde Pública da Universidade de São Paulo 1918 - 1945. Rev. Saúde públ., S. Paulo, 18(no esp.): 2-60, 1984.

disso, quantia equivalente a três mil dólares, como auxilio ao Departamento assim cria. do. Essa quantia foi arbitrada, na época, em 12 contos anuais.

Ainda de acordo com o contrato, caberia à Junta Internacional de Saúde fornecer quantia necessária para equipar a instituição, calculada em aproximadamente dez $\mathrm{mil}$ dólares; fundos para sua manutenção, durante o período estipulado pelo contrato e, finalmente, duas bolsas universitárias para estudo de higiene e saúde pública. Estas bolsas visavam a custear o preparo de dois médicos brasileiros na recém-criada Escola de Higiene e Saúde Pública da Universidade de Baltimore.

Em se tratando de cursos de higiene, o interesse da questão levara a Junta Interna. cional de Saúde a cuidar não apenas do provimento de uma Cadeira mas, a partir de perspectiva mais ampla, da criação de instituto científico destinado ao preparo de profissionais realmente especializados na matéria, onde se tornasse possível promover pesquisas sanitárias, métodos e processos sanitários de interesse para o país. De fato, pensara criar a Fundação, desde o início, Centro destinado à formação de sanitaristas capazes assim de enfrentar graves desafios nacionais a Saúde Pública e a substituir, aos poucos, antigos, dedicados, porém insuficientemente preparados funcionários dos serviços então existentes. Considerava-se, também, que esse preparo não se deveria dirigir apenas a individuos com forma. ção médica.

A Fundação Rockefeller passou a prestar auxulio à Faculdade de Medicina e Cirurgia de várias maneiras. A contribuição total foi a seguinte ${ }^{(1)}$ :

\section{Manutenção do Departamento de Higiene}

US\$ $148.876,20$

2. Donativo para a construção do Instituto de Higiene na Avenida Municipal

3. Bolsas de Estudo, conforme lista abaixo (estimativa aproximada)

Total em dólares US\$ $370.028,20$

Bolsistas

Geraldo Horácio de Paula Souza

Francisco Borges Vieira

Benjamim Alves Ribeiro

Paulo Cesar de Azevedo Antunes John Lane
Data

1918-1920

1918.1920

1931-1933

1941-1943

1941.1942
Local

Johns Hopkins

Johns Hopkins

Johns Hopkins

Johns Hopkins

Cornell
Quantia

$\$ 7.000,00$

$\$ 7.000,00$

$\$ 7.000,00$

$\$ 7.000,00$

$\$ 5.000,00$
Para efeito de complementação cumpre referir que, com seu empenho de contribuir para a elevação da qualidade da formação do pessoal de saúde pública por meio da criação de escolas de higiene, a Fundação Roc. kefeller concedeu verbas para várias institui- ções: a Universidade de Johns Hopkins recebeu 7.000.000 de d6lares; Praga 700.000; Zagreb 220.000; Copenhague 200.000; Budapest 150.000; Varsovia 300.000; Oslo 200.000; Londres 2.000,000; a Universidade de Harward 3.500.000; Ancara 80.000,

(1) Chope, H. D. Prncípios Fundamentais da Orientação da Fundação Rockefeller em relação a Escolas de Saúde Pública, Arquivo da Pró-Memória, FSP/USP. 
CANDEIAS, N. M. F. Memória histórica da Faculdade de Saúde Priblica da Universidade de São Paulo 1918 - 1945. Rev. Saúde públ., S. Paulo, 18(nọ esp.): 2-60, 1984.

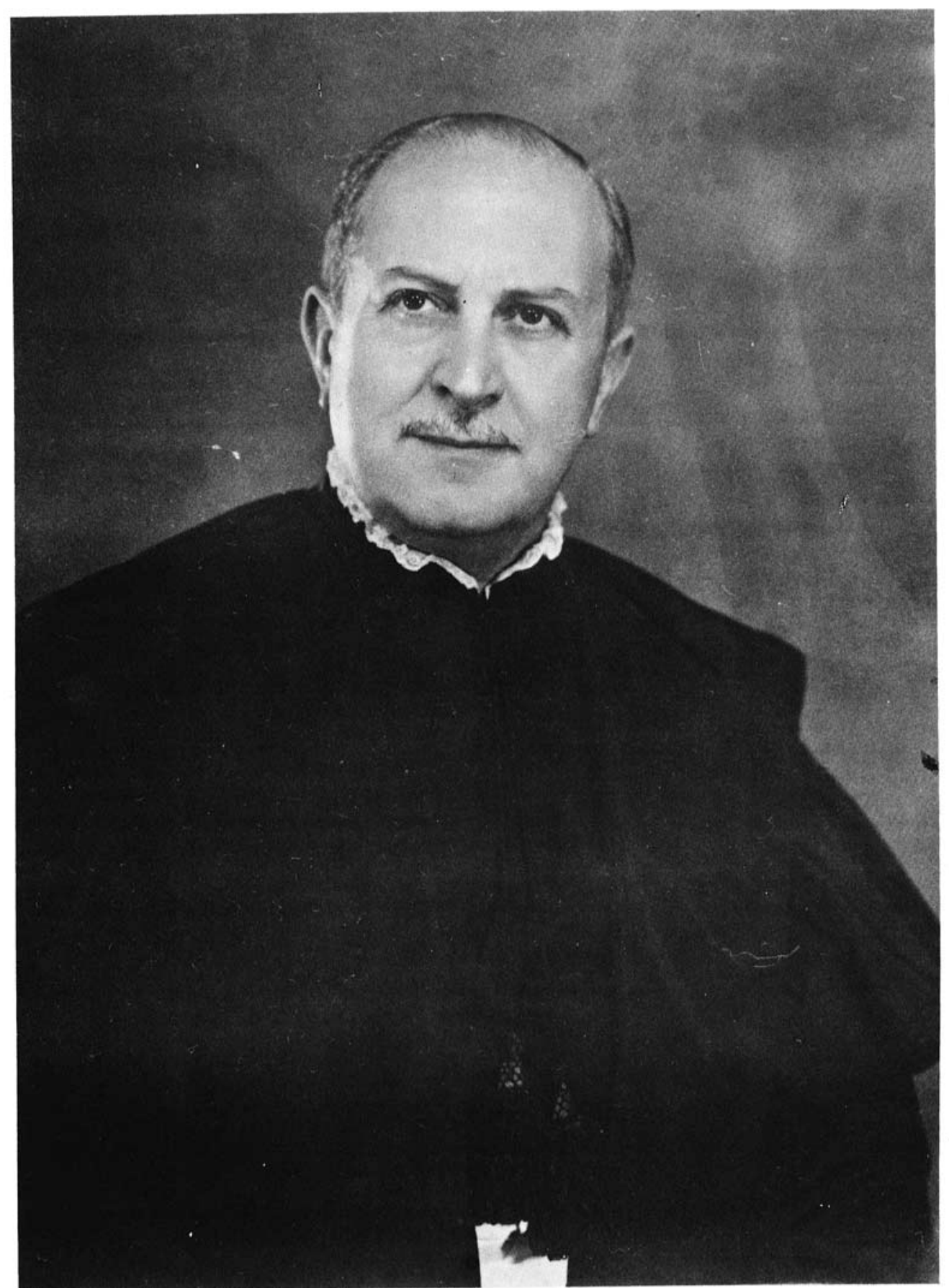

Geraldo Horácio de Paula Souza (1889-1951)

Fundador e Primeiro Diretor da Faculdade de Saúde Pública, USP. 
CANDEIAS, N. M. F. Memória histórica da Faculdade de Saúde Pública da Universidade de São Paulo 1918 - 1945. Rev. Saúde públ., S. Paulo, 18(no esp.): 2-60, 1984.

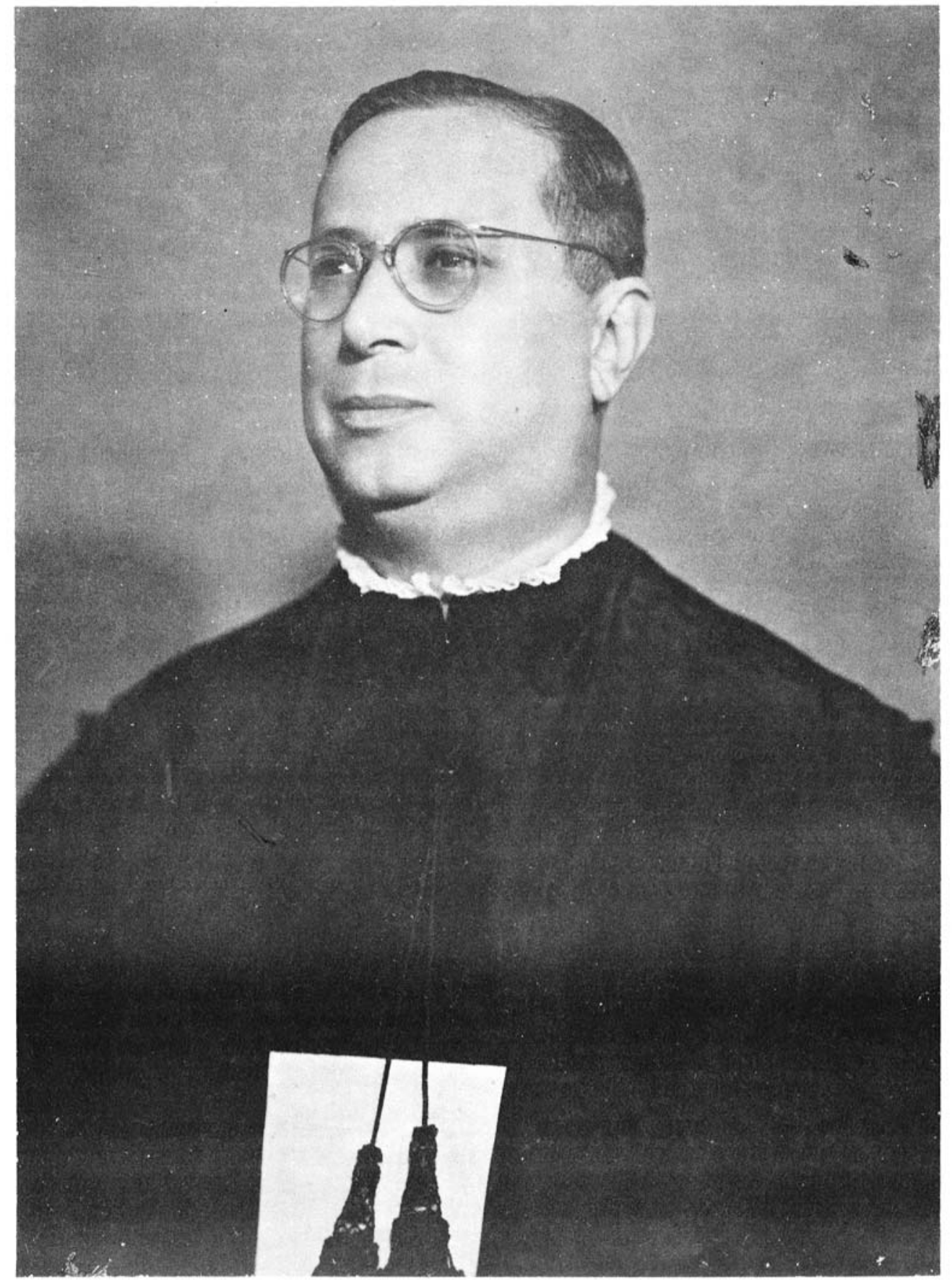

Francisco Borges Vieira (1893-1950)

Primeiro Vice-Diretor da Faculdade de Saúde Pública, USP. 
CANDEIaS, N. M. F. Memória histórica da Faculdade de Saúde Pública da Universidade de São Paulo 1918 - 1945. Rev. Saúde públ., S. Paulo, 18(no esp.): 2-60, 1984.

e São Paulo, como se viu, 370.000 dólares $^{(1)}$.

As relaçð̃es do Laboratório de Higiene com a Fundação foram mantidas, de início, com Wickliffe Rose, então Diretor da Seção de Saúde Pública da Comissão Rockefeller e, em seguida, com Frederick F. Russell que em 1922 veio ao Brasil para visitar o Instituto ${ }^{(2)}$.

\section{PRIMEIROS PROFESSORES DE HIGIENE}

Desde a sua fundação até 1921 , a Cadeira de Higiene, de acordo com o referido contra. to, foi regida por Samuel Taylor Darling, "de quem o Instituto guarda commovida lem. brança" que, nessa data, regressou aos Esta. dos Unidos por motivo de grave enfermida. $\mathrm{de}^{(2)}$. Técnico já consagrado em campanhas sanitárias, trabalhara com Gorgas no saneamento do Panamá, contribuindo assim para a abertura do canal, além de executar significativos estudos na Malásia e na Indonésia. Darling foi, pois, o primeiro professor de Higiene da Faculdade de Medicina de Sáo Pau. lo. Sob suas vistas instalou-se a cadeira e o Laboratório de Higiene, do qual foi tambem seu primeiro diretor. Coube a Wilson George Smillie, graduado em Harvard e discípulo do eminente higienista Milton Rosenau, substitui-lo na regência da Cadeira de Higiene e na direção do recém-criado estabelecimento. Foi, portanto, o segundo professor de Higiene e o segundo diretor do Laboratório de Higiene ${ }^{16}$.

Muito deve este país a estes dois eminen. tes cientistas. A par do prelecionamento da cadeira de Higiene realizaram importantes estudos nas áreas de epidemiologia e profilaxia da ancilostomose ${ }^{4}$. Fol durante o perfo. do Smillie que se introduziu o primeiro Curso de Especialização em Higiene Rural no Instituto de Higiene. Vale a pena referir aqui alguns trabalhos de Darling e Smillie, os quais se encontram nos primeiros números dos Boletins do Instituto de Hygiene, publicação que abrangeu o período de 1919 a $1946^{(3)}$ :

Boletim n? 1 - Sobre algumas medidas antimaláricas em Malaya, S.T., Darling

Boletim n 92 - Pesquizas recentes sobre a opilação na Indonésia, S.T., Darling

Boletim n? 3 - Intoxicação pelo Betanaphtol no tratamento da uncinariose, W.G. Smillie

Boletim n 94 - 0 predomínio da Leptospira ictero-hemorrhagica nos ratos de S. Paulo - Bacillos semelhantes aos da peste, encontrados nos ratos da cidade de S. Paulo, W.G. Smillie

Boletim nọ 7 - Existência e disseminação do ancylostoma duodenale no Brasil, W.G. Smillie

Boletim n:11- Investigaçðes sobre a uncinariose, W.G. Smillie

Logo após a chegada de Darling a São Paulo, seguiram para os Estados Unidos, com bolsas outorgadas pela Fundação Rockefeller a fim de freqüentarem o Curso da recém. -criada Escola de Higiene da Universidade de Johns Hopkins, Geraldo Horácio de Paula Souza e Francisco Borges Vieira ${ }^{16}$ :

' $E$ com saudade infinite que eu recordo,

(1) Correio da Tarde, 3 de abril de 1931: A margem da reforma do Instituto de Hygiene.

Nota: Com excę̧̃o das duas universidades americanas, não se especificam, no texto, as instituiçбes que receberam verbas em outros países.

(2) O Jornal, 12 de dezembro de 1926: Uma grande e modema Escola de Saúde Pública.

(3)Com a criação da Faculdade de Higiene e Saúde Pública a série foi interrompida, tendo dado lugar, em 1947, à publicação de "Arquivos da Faculdade de Higiene e Saúde Pública da Universidade de São Pau10". Em 1967, a Revista de Saúde Pública procurou atualizar seu órgão de comunicação na área da Saúde Pública. 


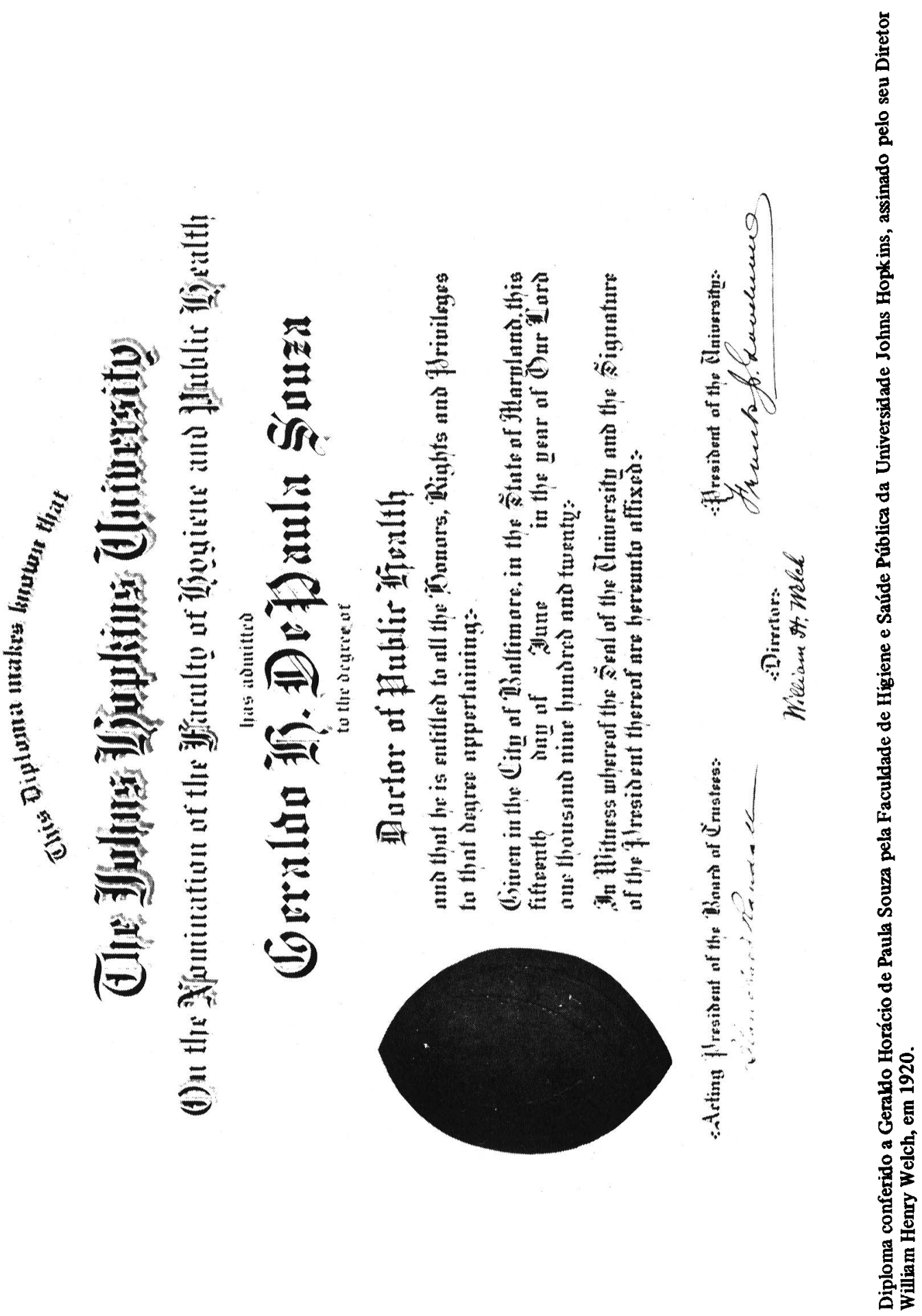


CANDEIAS, N. M. F. Memória histórica da Faculdade de Saúde Pública da Universidade de São Paulo 1918 - 1945. Rev. Saride públ., S. Paulo, 18(n? esp.): 2-60, 1984.

e o mesmo se dá com o Prof. Paula Souza, os dois annos que lá passamos, no convivio amigo de professores, assistentes e funcionários daquela grande Escola, que tudo fizeram a fim de que tirássemos o maior proveito de nossa estada, para a especializaçāo que abraçávamos. Em sua congregação brilhavam grandes nomes, entre eles avultando o do seu famoso organizador e diretor, o Dr. William Henry Welch, antigo discipulo e amigo de Pettenkoffer, Cohnheim, Pasteur, Koch e de outros luminares da ciência':

Com o regresso de Smillie para os Estados Unidos, em 1922, passou o estabelecimento a ser dirigido por Paula Souza, professor catedrático da cadeira de Higiene da Faculdade de Medicina e, assim, seu primeiro professor efetivo.

A este respeito comenta Paula Souza ${ }^{(1)}$ :

"Em 1918, fui indicado pelo saudoso Dr. Arnaldo Vieira de Carvalho, então Diretor da Faculdade de Medicina e Cirurgia de São Paula, à benemérita Fundação Rockefeller para, nos Estados Unidos, fazer o curso de doutoramento em Hygiene e Saude Püblica, que esta instituição acabara de crear na Johns Hopkins University, em Baltimore. Já então funccionava em São Paulo o Laboratório de Hygiene, no qual eu serviria como professor substituto e que, mantido por accordo do nosso governo com a Fundação Rockefeller, se destinava ao prelecionamento da cadeira de hygiene da nossa Faculdade de Medicina e Cirurgia para o preparo de especialistas em hygiene e pesquisas de ordem sanitária.

Dois annos depois, tendo concluido aquelle curso, quando me aprestava para regressar ao Brasil, solicitou-me o Dr. G. Vincent, Presidente da Fundação Rockefeller, que lhe apresentasse suggestōes a fim de que esta se pudesse informar de como mais conveniente a sua cooperação com o nosso Estado, em matéria de hygiene.

Respondi-lhe que, ausente de meu paiz por dois annos, esta circunstância me impossibilitava de precisar, com segurança, quais as necessidades do meio a attender.

Regressando a São Paulo, foi-me depois, confiada a direç̧̄ōo desse Laboratório, então annexo à Faculdade de Medicina, o qual se denominava Instituto de Hygiene e, nessa qualidade, passei eu a reger a cadeira respectiva $e$ a dirigir a instituição que até então estivera a cargo de technicos americanos".

Estatuira-se durante a negociação entre o Governo e a Junta Internacional de Saúde Pública que aquele faria o possível para manter o Departamento sem contudo assumir qualquer compromiso. Terminado o prazo no início de 1923, quando já o Instituto de Higiene estava, como previsto, sob a direção de Paula Souza, opinou o Governo por sua renovação por um período de mais dois anos, sendo aceitas por ambas as partes as mesmas bases do contrato anterior ${ }^{(2)}$.

\section{A CASA DA RUA BRIGADEIRO TOBIAS}

Como se referiu, já em 1918, ao formar-se o acordo entre o Governo de ST̃o Paulo e a Fundação Rockefeller, concordara aquele em fornecer prédio apropriado aos fins propostos. A Faculdade de Medicina fora insta. lada em casarão alugado de Dona Vitória Pinto de Almeida Lima, na Rua Brigadeiro Tobias, antigo no 42. 0 Instituto de Higiene foi situado na mesma rua, antigo n! 45 , (Caixa Postal 1985), em prédio pertencente à Baronesa de Piracicaba, que o cedeu median. te arrendamento firmado com a Faculdade ${ }^{14}$.

(1) Carta enviada por Paula Souza a Joăo Galeão Carvalhal Pinto, Secretário do Interior, no período de 6 de maio de 1927 a 13 de julho de 1927. A data não consta na cópia. Arquivo da Pró-Memória, FSP/USP.

Nota: Conservou-se a ortografia da época na grafia das palavras dos textos e cartas aqui reproduzidos.

(2) O Jornal, 12 de dezembro de 1926: Uma grande e moderna Escola de Saúde Pública. 
Constava no contrato de $1922:^{(1)}$

"Aos doze de setembro de mil novecentos e vinte e dois, na Secretaria de Estado dos Negócios do Interior, perante o respectivo Secretário, Exmo. Snr. Dr. Alarico Silveira, compareceu a Exma. Snra. Da. Maria Joaquina de Barros, Baroneza de Piracicaba, proprietária, residente nesta Capital, representada por seu bastante procurador, Snr. João Tobias de Barros, commerciante, residente nesta Capital, conforme procuração que fica archivada nesta Secretaria, declarou que sendo senhora e possuidora do prédio sito à Rua Brigadeiro Tobias sob no 45, livre e desembaraçado de qualquer ômus, o dá de arrendamento ao Governo do Estado, com todas as suas dependências e terreno annexo, para nelle funcionar uma das seç̧ōes da $\mathrm{Fa}$ culdade de Medicina e Cirurgia, declarando mais que acceitava as clausulas seguintes:

\section{$I$}

$O$ prazo de arrendamento será de 2 (dois) annos, a contar do dia 5 de agosto deste anno, em que forem entregues as chaves ao Snr. Dr. Celestino Bourrold, director da Faculdade de Medicina;

\section{II}

$A \cdot$ renda mensal do aluguel será de 4:000\$000 (quatro contos de réis) quantia essa que será paga pelo Thesouro do Estado, nos cinco primeiros dias seguintes ao mez vencido".(2)

Situada na Rua Brigadeiro Tobias, onde se localizavam outras entidades de ensino, a casa compunha-se de dois andares. De proporçōes harmoniosas, representava belo exemplo dos casarões do fim do século XIX. No andar térreo, a fachada continha, no corpo central, três portas ladeadas por uma janela. $\mathrm{O}$ acesso à casa dava-se por escada bila. teral, com seis degraos, culminando em um terraço, emoldurado por belíssima grade de ferro forjado, importado da Europa. prova. velmente da Bélgica de onde provinham as grades e esquadrias que guarneciam os pala. cetes da época. No andar superior havia qua. tro portas, com seus respectivos terraços ornados por grades de ferro, dois de cada um dos lados do prédio. No centro, três outras portas comunicavam-se por terraço comum. Portas e janelas constituiam uma forma de enriquecimento da fachada. $O$ tratamento do telhado revestia-se de especial importância, considerando-se a linha reta apenas cortada por estátuas portuguesas de cerâ. mica do Porto, caracterizando o estilo neo. -clássico tipicamente representativo do gosto de "fim de século". 0 casarão era todo cerca. do por jardins de modelo francês, provavel. mente projetado por jardineiro dessa procedência ou copiado de outros realizados por jardineiros franceses que imigraram para 0 Brasil durante o século XIX. ${ }^{(3)}$

(1) A Cadeira de Higiene permaneceu na Rua Brigadeiro Tobias de 1918 até agosto de 1931. Nessa ocasiâc foi transferida para o prédio atual da Faculdade de Saúde Pública. O arquivo da Pró-Memória da FSF possui apenas a cópia do contrato de 1922.

(2) Termo de contracto de arrendamento do prédio n. 45, da Rua Brigadeiro Tobias, nesta Capital, celebrado entre o Governo do Estado e a Exma. Snra. Baroneza de Piracicaba. Arquivo Pró-Memória, FSP/USP.

(3) As Fotografias da casa da Rua Brigadeiro Tobias foram doadas à Comissão Pró-Memória, FSP/USP, pelo Dr. Vicente de Sampaio Lara, professor aposentado, catedrático de Higiene da Criança da Facul. dade de Saúde Pública. 
CANDEIAS, N. M. F. Memória histórica da Faculdade de Saúde Pública da Universidade de São Paulo 1918 - 1945. Rev. Saude publ., S. Paulo, 18(n? esp.): 2-60, 1984.

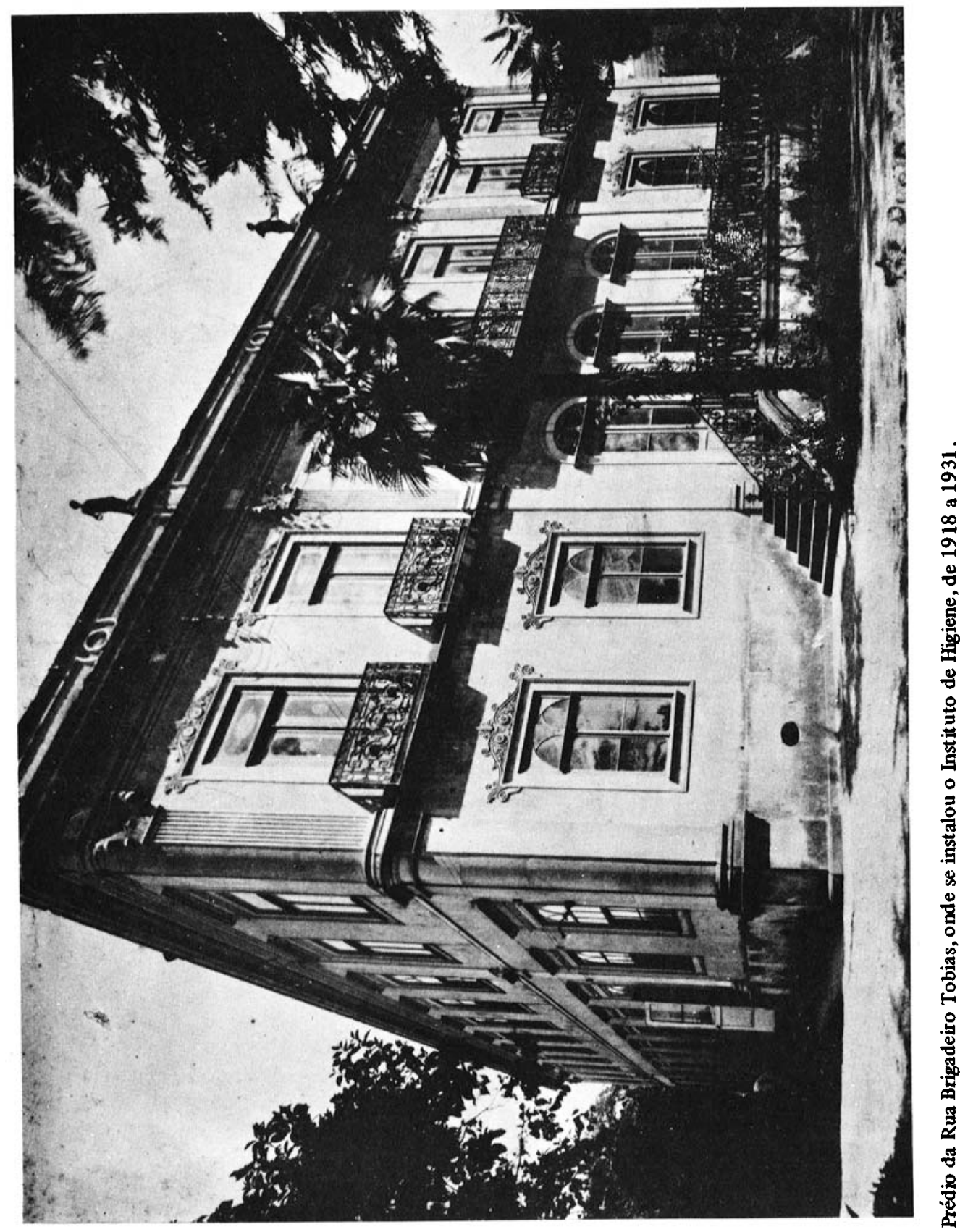


CANDEIAS, N. M. F. Memória histórica da Faculdade de Saúde Pŕblica da Universidade de São Paulo 1918 - 1945. Rev. Saúde públ., S. Paulo, 18(nọ esp.): 2-60, 1984.

\section{A OFICIALIZAÇÃO DO INSTITUTO DE HIGIENE}

Extinto como já se disse, o contrato firmado entre o Governo do Estado e a Jun. ta Internacional de Saúde da Fundação Rockefeller - contrato que fora reformado, dois anos antes, por proposta do primeiro e plena acqüiescência do segundo - para manutenção do Laboratório da Cadeira de Higiene da Faculade de Medicina por parte desta, foi esse estabelecimento oficializado pela Lei no 2018 de 26 de dezembro de 1924, a qual dispunha sobre a oficialização do Ins. tituto de Higiene. Desta data em diante, deixou o Instituto de Higiene de funcionar como seção da Faculdade de Medicina e Cirurgia de São Paulo, constituindo-se em repar. tição distinta daquela e com atribuições no. tavelmente acrescidas.

Vejamos o teor desse decreto:

'Dispõe sobre a officialização do Instituto de Hygiene de São Paulo. O Doutor Carlos de Campos, Presidente do Estado de São Paulo. Faço saber que o Congresso Legislativo decretou e eu promulgo a lei seguinte:

Artigo 19- De 19 de janeiro de $1925 \mathrm{em}$ diante, o Instituto de Hygiene, organizado, installado e mantido pelo Governo de São Paulo e pela Junta Internacional de Saude, nos termos do contrato de 9 de fevereiro de 1918, funccionará independente de qualquer indemnização, como departamento administrativo exclusivamente do Estado, sob a denominaçāo de Instituto de Hygiene de São Paulo e diretamente subordinado ao secretário dos Negócios do Interior".

Deste modo passara o Instituto a ter, entre outras, as seguintes finalidades: realizar o curso de higiene da Faculdade de Medicina de São Paulo de acordo com as exigências do ensino da cadeira, assim como cursos de aperfeiçoamento técnico para funcionários do Serviço Sanitário, de habilitação profissional para enfermeiras e visitadoras de saúde pública e outros especiais que viessem a ser instituídos por lei ou considerados de interesse para o Governo; finalmente, orientar o ensino popular de higiene e o que se denominava, na época, de "propaganda sanitária".

Os diplomados pelo Instituto de Higiene tinham, com isto, preferência para o provimento de cargos técnicos do Serviço Sanitá. rio. Comenta Mascarenhas que, infelizmente, não se respeitou essa determinação legal com graves reflexos para o nível técnico dos serviços de saúde pública de São Paulo ${ }^{8}$.

Caminhavam assim Paula Souza e Borges Vieira rumo aos objetivos que tão entusiasticamente haviam se proposto a alcançar: criar uma "verdadeira escola de higiene e de saúde pública", capaz de formar sanitaristas, de alta qualidade técnica, provenientes de várias áreas de conhecimento, a partir de uma pers. pectiva essencialmente multiprofissional. Eis, pois, a primeira proposta de criação de uma equipe de saúde na história da Saúde Pública do nosso país, concepção certamente adiantada para sua época.

A propósito da oficialização do Instituto de Higiene, publicava a "Folha da Tarde" em 30 de novembro de 1924:

“. . Agora que terminou o prazo, o go verno officializou o Instituto de Hygiene, com o qual quasi nada tem gasto até o momento. O Instituto, como escola de hygiene que $\dot{e}$, ficou sob a dependência directa da Secretaria do Interior, pois não só da Faculdade como também de outras escolas superiores depende a collaboração para os seus cursos, pesquizas, installações, etc. Afinal o que o governo paulista acaba de fazer é, portanto, tornar official um estabelecimento que embora viesse sendo mantido por capi. taes vindos de fora do paiz estava, de tres annos a esta parte, sob a direcção immediata e exclusiva de profissionais brasileiros".

Com esse ato passavam para o exclusivo domínio do Estado todos os bens com que a Comissão Rockefeller havia dotado o estabelecimento: aparelhos, material de ensino, móveis, instalaçð̃es, biblioteca, entre outros.

Dera-se, portanto, importante passo "quiseram os fados que viesseis a trocar $\mathrm{Pa}$ nacea por Higea ${ }^{(1) ", . ~}$

(1) “O Estado de São Paulo", 6 de janeiro de 1944: Escola de Higiene e Saúde Pública - discurso do paraninfo, dr. Francisco Borges Vieira, por ocasião da entrega de diplomas. 
CANDEIAS, N. M. F. Memoria histórica da Faculdade de Saúde Páblica da Universidade de São Paulo 1918 - 1945. Rev. Saúde públ., S. Paulo, 18(no esp.): 2-60, 1984.

\section{CRITICAS A OFICIALIZAÇÃO}

A proposta da subordinação de Instituto de Higiene diretamente ao Secretário dos Negócios do Interior, tal como constava no artigo 1 o da lei 2018 de 1924 , além de discutida foi amplamente criticada nos perídicos da época. Vejamos porquê.

Publicara o Correio Paulistano alguns dias antes, em 18 de dezembro de 1924, a opinião de Piza Sobrinho, em sessáo da Câ. mara, a respeito do Projeto $n$ o 78 que dispunha sobre a oficialização do Instituto de $\mathrm{Hi}$ giene:

'Este artigo subordinando directamente ao secretario dos Negócios do Interior, o Instituto de Hygiene que, diga-se de passagem, tem, pelo projecto, as mesmas atribuif̧ões, em geral, que o Serviço Sanitário, traz o grave inconveniente, que ja apontei, de estabelecer no Estado duas directorias do Serviço Sanitário, abosolutamente independentes, apenas subordinadas, ambas, ao secretario do Interior, que estou quasi certo, si isso acontecer com a aprovação do projecto em discussāo, terá o seu precioso tempo sempre tomado em resolver questiunculas, attritos entre os dois chefes dos mesmos serviços".

Estranhava Piza Sobrinho em sua longa exposição o fato de, a exemplo do que ocorria com o Instituto Bacteriológico, Instituto Vacinogênico e Instituto Pasteur, entre outros então subordinados à Directoria Geral do Serviço Sanitário, não se subordinar a esta o novo Instituto de Higiene:

'Por que excluir dessa natural e lógica subordinação o Instituto de Hygiene, um instituto eminentemente téchnico? Estará melhor sob a immediata superintendência de um secretario de Estado, quasi sempre bacharel em direito, o Instituto de Hygiene, do que subordinado a um profissional, a um technico quasi sempre notável, como deve ser o director geral do Serviço Sanitário?

Accresce que o Instituto de Hygiene, com a sua nova organização, será da mesma natu. reza que o Instituo Bacteriológico e Butan- tan, não sendo plausivel que estes estejam sob a direç̧ão superior do Serviço Sanitário e aquelle nẫo. (Muito bem)."

Além disso criticava Piza Sobrinho algumas atribuiçōes do novo Instituto de Higiene:

“( $L \hat{e})$

- estudar planos e methodos de campanha sanitaria e adaptal-os ao meio indicado;

- emitir parecer sobre assumptos de hygiene e organizar commiçōes especiaes para $o$ seu estudo mediante requisicão do go.

verno, para fins ou casos por este especificados;

- verificar os sóros e vaccinas expostos à venda $e$ estabelecer a padronagem delles;

- fazer estudos de epidemiologia, no interesse de pesquisas scientificas, - do Serviço Sanitário - e do ensino professado em seus cursos de Hygiene;

- orientar o ensino popular de Hygiene e a propaganda sanitária em geral."

Comentava aquele que essas atribuiçōes constituiam já atuais atribuições da Diretoria Geral do Serviço Sanitário, enumeradas no capítulo II do Código Sanitário, passando a fazer comentários específicos às implicações inerentes a cada uma delas.

A respeito da oficialização do Instituto de Higiene cumpre referir, também, debate envolvendo Freitas Valle e Rodrigues Alves ${ }^{(1)}$, publicado no "Correio Paulistano" no dia 24 de dezembro de 1924:

"O Sr. Freitas Valle - O ponto capital do discurso de S. Exc., combatendo os dispositivos do projecto, visa a demonstraçäo de que há uma verdadeira confusão na discriminação das funcções do Serviço Sanitário e do Instituto de Hygiene cuja officialização se cogita.

O Sr. Rodrigues Alves - Não é bem uma confusāo. $E^{*}$ uma dualidade de funcções: são funç̧ōes idênticas.

O Sr. Freitas Valle - Não há duplicação de funcçōes. O Instituto de Hygiene é um orgam pelo qual se apercebem os elementos do Serviço Sanitário para desempenhar a

(1) Discurso de Oscar Rodrigues Alves, no Senado, contra a oficialização do Instituto de Higiene. 
CANDEIAS, N. M. F. Memória histórica da Faculdade de Saúde Pública da Universidade de São Paulo 1918 - 1945. Rev. Saude públ., S. Paulo, 18(n? esp.): 2-60, 1984.

sua alta funç̧ão de defesa de saúde pública.

$O$ fato de, ao mesmo tempo, o Instituto proceder a certos trabalhos especiais, é explicado por não se poder ensinar praticamente Hygiene sem fazer-se o serviço de hygiene correto com o ensino que se quer praticar.

"Já se foi o tempo em que ensinar hygie. ne se podia fazer pelos compendios e pelas fórmulas mais ou menos empiricas, que tinham apenas o resultado de fadigar a paciência e a memória dos que apprendiam. Hoje a fórmula perfeita da docência do ensino de hygiene, é ensinar, fazendo trabalhar no ensino de hygiene. . .

... Acredito ser certo o que V. Exc. affirmou, isto $\dot{e}, q u e$ vários funccionarios que trabalham no Instituto de Hygiene säo funccio. narios do Serviço Sanitario. Mas isso em nada altera a organização e a orientação pedagogica do Instituto; isso não altera em nada os outros serviços prestados pelo Instituto.

O Sr. Rodrigues Alves - Mas trata-se da execuçāo de serviços que, por lei, pertencem a um departamento já organizado, que é o de prophylaxia geral.

O Sr. Freitas Valle - . . Essas circunstâncias todas mostram que o nobre senador não tinha perfeita razão, entendendo que no caso de virem as funcções especificadas no projecto para o Instituto de Hygiene havia capitis diminutio para o Serviço Sanitário.

Em primeiro logar, em materia scientifica não existe capitis diminutio; em materia de serviço publico não é possivel capitis diminutio. Uma disposição legislativa nunca pode diminuir a quem quer que seja, instituto ou individuo".

Segue-se interessante discussão envolvendo o Instituto Butantan, o Hospital de Isolamento, onde funcionava também o Instituto Bacteriológico, e consideraçðes a respeito dos vencimentos mais elevados dos funcionários do Instituto de Higiene, entre outros assuntos também abordados:

"Freitas Valle - ... Um ponto que im. pressionou o Senado e ao qual vou referir-me é a tabella de vencimentos, na parte em que inscreve: "Uma enfermeira chefe 12:000\$000 por anno". Devo informar, como bem obser- va o nobre senador, que se fosse uma enfermeira chefe, tendo sob sua dependência apenas uma outra enfermeira, seria realmente uma cousa extranhável. . . Essa enfermeira é uma enfermeira chefe no sentido de ser orientadora, mestra, professora em relação ao ensino que ali deve ser feito para as enfermeiras, e ella recebe uma remuneraçäo pelos grandes serviços que presta e que, realmente, em nāo se tratar de uma simples enfermeira, como parecera a todos nós, inclusive ao nobre senador. . .

. . . Há uma disparidade extraordinária, muito bem notada pelo nobre senador, mas que posso prometter a $S$. Exc. será attendi. $d a$, por occasião da revisão geral dos funccionários e empregados do Estado. . .

. . Para terminar com uma impressão agradável ao nobre senador e ao Senado, uma vez que não posso pensar tel-o conseguido com a minha desataviada palavra (não apoiados geraes), declarei aceitar a emenda no 4 no paragrafo 19 do artigo 89, assignada por vários srs. senadores e por s. exc. apre. sentada, modificando-lhe os termos da seguinte forma: (Lê): "Poderão ser applicadas aos funccionários do Serviço Sanitario em condições idênticas ao dispositivos do presente artigo e seus paragraphos 19 e $2 \%$.

De sorte que, em logar de somente os mérir,us, todos os funccionários do Serviço Sanitário passarão a gosar da vantagem que se estabelecia no projecto apenas para os funccionários do Instituto de Hygiene.

Eis, sr. presidente, o que eu tinha a dizer a respeito do projecto em discussão, propondo que o Senado rejeite as demais emendas, acceitando a da Commissão e a dos nobres senadores, sob a forma que acabei de ler $e$ que será apresentada, nestas condições, no carater de sub-emenda substitutiva.

Vozes - Muito bem! Muito bem!"

Para alguns políticos da época, a lei 2018 de 26 de dezembro de 1924 parecia atribuir ao Instituto de Higiene atividades pertinentes ao Serviço Sanitário. Aquele, por sua vez, representava apenas uma nova instituição, porém análoga a outras já existentes. Para Paula Souza, ao contrário, não se poderia considerar o Instituto de Higiene, como in- 
CANDEIAS, N. M. F. Memória histórica da Faculdade de Saúde Pública da Universidade de São Paulo 1918 - 1945. Rev. Saúde públ., S. Paulo, 18(no esp.): 2-60, 1984.

sinuava o parecer de Piza Sobrinho, instituto de natureza eminentemente técnico mas, isto sim, núcleo inicial de futura unidade autônoma de ensino de uma Universidade ainda inexistente.

Além de problemas de ajustamento interinstitucional também se criticava, na época, a atuação da Fundação Rockefeller junto ao Instituto de Higiene. Dizia o "Diário da Medicina", do Rio de Janeiro, em suas "Not1. cias de Sáo Paulo", no dia 8 de abril de 1925:

". . surge entāo no Congresso estadual e nas columnas dos jornaes, certas accusaçōes à Rockefeller que, segundo os seus gratuitos inimigos, desejaria implantar aqui a influência americana.

Mas o que é certo é que os acontecimentos vêm provando justamente o contrário do que então se disse. Pois além de subordinar a administração do Instituto de Hygiene à nossa administração, a Rockefeller doou ao nosso Estado todas as installações que aqui possuia.

. . Cumpre notar ainda que todo o pessoal que trabalha no Instituto é nacional."

O fato é que a Lei no 2018 de 1924 permi. tira que o antigo Laboratório da Cadeira de Higiene da Faculdade de Medicina se transformasse, segundo manchete de "O Diário da Noite" em 15 de dezembro de $1926^{(1)}$, em "Uma grande e moderna escola de Saúde Pú. blica:

“. . Perfeito "gentleman", o Dr. Paula Souza promptamente nos attendeu, não só encantando-nos com o brilho de sua palestra de fino "causer", como ainda mandando dar-nos todas as informaçōes que, sobre o Instituto de Hygiene, a nossa curiosidade pedia."

Informa Paula Souza durante essa entrevista que, além do curso da cadeira de Higie- ne da Faculdade de Medicina, o Instituto ministrava tamberm os seguintes cursos: doutor em higiene destinado a médicos; engenheiros sanitários, técnicos de laboratório de saúde pública, visitadoras de saúde pública para enfermeiras diplomadas, auxiliares de higiene escolar para professoras do magistério primário e cursos intensivos de aperfeiçoamento técnico sobre assuntos de higiene.

Os serviços técnicos do Instituto conta. vam entăo com as seguintes seçб̄es:

- Seção de Epidemiologia, a cargo de Fran. cisco Borges Vieira;

- Seção de Parasitologia, a cargo de Samuel Barnsley Pessoa;

- Seção de Microbiologia, a cargo de Alberto Santiago;

- Seção de Psicotécnica, a cargo de Benjamim Alves Ribeiro;

- Seção de Química e Bioquímica, a cargo de Geraldo Horácio de Paula Souza, tendo como auxiliar Alexandre Wancolle. Anexos ao Instituto passaram a funcionar o Posto Experimental da Lepra e o Centro de Saúde Modelo ${ }^{(2)}$.

O Posto Experimental da Lepra, informava Paula Souza, tinha como principal função fornecer campo de pesquisa para médicos de São Paulo e alunos de Faculdade de Medicina, os quais não contavam anteriormente com centro de estudos práticos de lepra. Este passara a funcionar como dispensário, atendendo doentes, suspeitos e comunicantes, e oferecendo oportunidades para estudo da moléstia. Era responsável por esse Serviço José Maria Gomes, Chefe do Serviço de Profilaxia da Lepra no Estado de Sáo Paulo, tendo, como auxiliares, os anatomo-patologistas Paes de Azevedo, Pateo Junior e F. Leitão.

O Centro de Saúde Modelo, anexo ao Instituto, passou a ser considerado dispensário padrão de outros que, posteriormente, deve-

(1) Nessa época, 1926, Paula Souza ocupava o cargo de Diretor do Serviço de Saúde Pública do Estado.

(2) O Centro de Saúde decorrera de reforma do Código Sanitário realizada por Paula Souza em 1925, como Diretor do Serviço de Saúde Pública do Estado. 
CANDEIAS, N. M. F. Memória histórica da Faculdade de Saúde Pública da Universidade de São Paulo 1918 - 1945. Rev. Saúde públ., S. Paulo, 18(no esp.) : 2-60, 1984.

riam ser fundados pelo Serviço Sanitário na cidade de Sáo Paulo.

A par disso, já contava o Instituto de Higiene com biblioteca constituída por mais de 4.000 volumes, classificados pelo sistema Dewey internacional.

Assim se encontrava o Instituto de Higiene seis anos após a sua criação.

\section{O PRÉDIO DA AVENIDA DR. ARNALDO ANTIGA AVENIDA MUNICIPAL}

A renovação do contrato entre a Funda. ção Rockefeller e o Governo do Estado, assim como a Lei 2018 de 1924, haviam permitido transformar o Laboratório de Higiene da Faculdade de Medicina no Instituto de Higiene. Ao conceder-Ihe a autonomia necessária para seu melhor desenvolvimento, nem por isso se rompiam os laços entre a Faculdade de Medicina e o Instituto de Higiene, com óbvias vantagens para Higea e Panacea. Nð̃o implicara isto, entretanto, no distanciamento entre as duas entidades uma vez que o pró. prio regulamento cuidara por entregar a direção do Instituto à chefia da Cadeira de Higiene da Faculdade de Medicina.

Em sinal de apreço por esse gesto do Governo, a Fundação Rockefeller renunciou, em favor da Instituição, a seus direitos sobre a propriedade do estabelecimento por ela equipado. Além disso passou a promover os passos necessários para atender à solicitação de Paula Souza que, já em 5 de janeiro de 1925 , solicitara à Fundação Rockefeller que lhe fosse outorgada a quantia de 1:500\$000 contos, destinada a auxiliar a construção de prédio adequado às novas e múltiplas fun. ções de ensino e investigação(1) (2).

Alguns anos antes da promulgação da lei de 1924, já após o falecimento de Arnaldo Vieira de Carvalho, recebera Paula Souza carta de Wickliffe Rose, com data de 10 de janeiro de 1921, onde se discutiam aspectos relacionados à construção dos novos prédios da Faculdade de Medicina, à filosofia que deveria moldar o novo Instituto de Higiene e, ponto crucial, o relacionamento ideal entre as duas entidades: ${ }^{(3)}$

"O senhor me perguntou se seria possivel à Fundação Rockefeller conceder fundos para o Governo de São Paulo para a construção dos prédios da Faculdade de Medicina, fundos estes que seriam pagos mais tarde com juros.

... Concordamos com o senhor que o Instituto de Hygiene deva ser mais do que um Departamento de Hygiene para ensino de estudantes de graduação da Faculdade de Medicina. O Brazil parece estar entrando em um periodo de desenvolvimento. Está havendo um sentimento crescente de apoio à Saude Pública. Os governos Federal e Estadual estão criando fundos para objetivos de saúde puiblica; os Departamentos de Saude estão sendo reorganizados e novas atividades estão sendo desenvolvidas. Tudo isso exigirá pessoal treinado. É preciso que haja em solo brasileiro uma instituição adequadamente equipada que cultive a Higiene, como ciência, assim como o treinamento de homens e mulheres para trabalho prático de saúde pública. Parece que o jovem Instituto de Hygiene, que acaba de surgir em São Paulo, deva aspirar a liderança desse movimento.

importante, contudo, que o desenvolvimento do Instituto de Hygiene se ponha lado a lado como desenvolvimento da administração da saude pública, por um lado, e, por outro, com o desenvolvimento da Faculdade de Medicina e o interesse do governo no desenvolvimento desta instituiçäo particular.

Concordamos com o seu ponto de vista que, o que quer que se faça no presente, no que diz respeito à construção ou equipamento para a Faculdade de Hygiene, deve-se ter sempre em mente seu desenvolvimento futuro mais amplo, deixando espaço para a necessária expansão no futuro.

Além disso, concordamos com seu ponto

(1) Documento sem título e sem data, marcado apenas com o no 16, Comissāo Pró-Memória, FSP/USP.

(2) Carta dirigida por Paula Souza a João Carvalhal Filho, Secretário do Estado dos Negócios do Interior. Cópia sem data. 
CANDEIAS, N. M. F. Memória histórica da Faculdade de Saúde Pública da Universidade de São Paulo 1918 - 1945. Rev. Saude públ., S. Paulo, 18(nO esp.): 2-60, 1984.

de vista que o Instituto de Hygiene deva estar intimamente relacionado com a Faculdade de Medicina, por um lado e, por outro deva ter individualidade própria. Discuti recentemente esse assunto com o Diretor da Faculdade de Medicina de Harvard em termos da possibilidade de desenvolver um Instituto de Hygiene nessa Universidade. Acha que o Instituto de Hygiene precisa de prédio próprio; deve contar com individuos com dedicação exclusiva à Hygiene e Sauide Püblica $e$ identificados exclusivamente com o Instituto; $e$, por outro lado, o Instituto deve estar próximo da Faculdade de Medicina, se possivel no seu campus. .."

Em 28 de março de 1921, sob a administração de Edmundo Xavier, Diretor da Faculdade de Medicina no período de 21 de fevereiro de 1921 a 21 de fevereiro de 1922 , iniciaram-se entendimentos para alojar definitivamente as várias cadeiras da Faculda$\mathrm{de}^{14}$. Em carta dirigida a Wickliffe Rose, solicitou o Diretor a vinda de um técnico para orientar a construção dos futuros edifícios, aconselhando-se junto à Fundação so. bre como organizar e aperfeiçoar a educação médica em São Paulo. Essa carta foi respondida por George E. Vincent, mostrando-se este bastante favorável à idéia. Foi durante a gestão de Celestino Bourroul (2 de março de 1922 - 11 de dezembro de 1922), em fevereiro de 1922, que Pearce, Diretor do Departamento de Educação Médica da Fundação Rockefeller, voltou novamente a São Paulo. Várias foram as sugestões por ele apresentadas quanto ao aperfeiçoamento do ensino médico. Aceitas pela Congregação, em ses. são de março de 1922, foram as mesmas en. viadas ao Governo do Estado, tendo a Fun. dação tomado conhecimento, por intermédio de Pearce, de que a Faculdade as havia aceito. De regresso aos Estados Unidos com a notícia de que a Faculdade aceitara a cooperação da Fundação, concedeu esta, no dia
24 de maio de 1922, o almejado auxílio para aquela Instituição.

Em 1925, ao ser integrado na administração do Estado, com o quadro de pessoal bastante acrescido e percebendo vencimentos por conta deste, recebeu o Instituto da Fundação Rockefeller o valioso auxulio de 1.500 contos para construção do novo pré. dio $^{(1)}$

A idéia da doação devera-se a Frederick F. Russell, Presidente da Junta Internacional da Saúde, que a propôs a Comissão da Fundação em uma de suas reuniōes anuais. Com a anuência do Governo, uma vez aceito o donativo, deu-se início aos estudos e trabalhos preliminares da construção do novo edifício para o então denominado "Instituto de Hygiene".

Os planos do novo prédio foram delineados por Paula Souza que, ao organizar as plantas dos diversos andares, fundamentou seu trabalho nos mais modernos preceitos a que se deveria submeter uma Escola de Higiene na época. Aprovadas as plantas pelo Governo, foram elas enviadas à Fundação Rockefeller. Foi quando se fez, para São Paulo, a transferência do equivalente a 50.000 dolares, cerca de $350.000 \$ 000$, quantia depositada inicialmente no Banco do Comércio e Indústrias, passada, em seguida para o Tesouro do Estado.

Um ponto de alta significação foi o critério predominante, sobriedade do acabamento interno e externo. As construções realizadas sob auspícios da Fundação Rockefeller apresentavam essas características. Pau. la Souza traçou o plano do prédio com a mais rigorosa simplicidade, especialmente em sua parte interna, tipos de portas e janelas, gênero de pintura e plano das canalizações de eletricidade, água, gás e esgoto, todos aparentes. Isto despertou comentários de en. genheiros civis e de médicos que lamentavam, na época, o sacrifício do aspecto inter-

(1) Exposição de Motivos sobre o Projecto de Construcção do Novo Prédio para o Instituto de Hygiene, Accompanhada de Orçamento apresentado pela Firma Siciliano e Silva para Aquelle Fim Escolhida, Arquivo Pró-Memória, FSP/USP. 
CANDEIAS, N. M. F. Memória histórica da Faculdade de Saúde Pública da Universidade de São Paulo 1918 - 1945. Rev. Saúde públ., S. Paulo, 18(no esp.): 2-60, 1984.

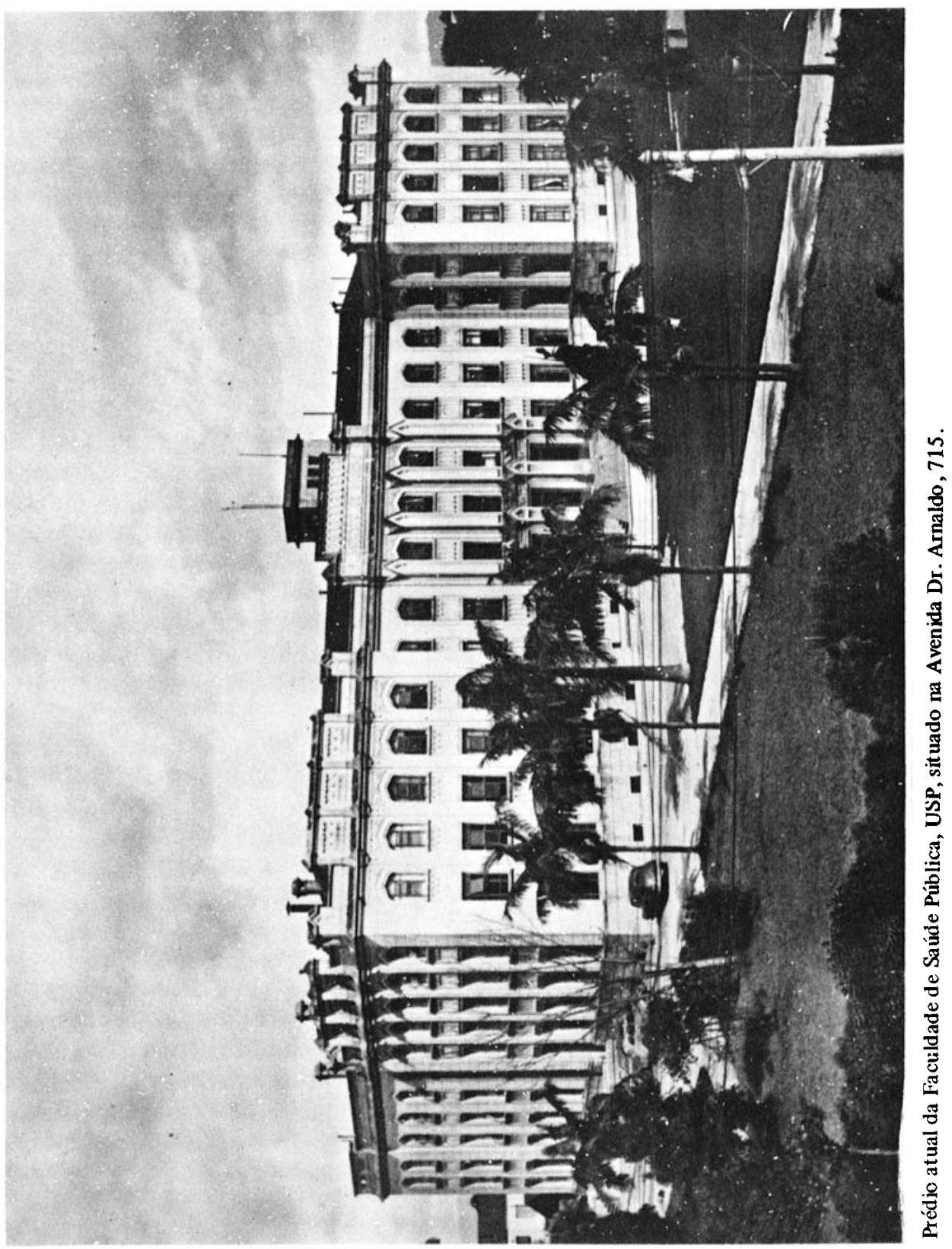


CANDEIAS, N. M. F. Memória histórica da Faculdade de Saúde Pública da Universidade de São Paulo 1918 - 1945. Rev. Saude puibl., S. Paulo, 18(no esp.): 2-60, 1984.

no, sem considerar as vantagens daí decorrentes.

Em 15 de agosto de 1926, noticiava o "Jornal do Commercio": "Será lançada brevemente, no terreiro fronteiro ao novo prédio da Faculdade de Medicina, no Araçá, a primeira pedra do Instituto de Higiene". Para que a memória não se perca, vejamos algumas características do prédio que a persistência de Paula Souza permitira erguer ${ }^{(1)}$.

Projeto: três pavimentos com área de $1.547 \mathrm{~m}^{2}$ cada um. O Primeiro reservado para serviços em contato com o público, como Centro de Saúde, Curso de Educadores Sanitários, Sala de Conferências, Portaria, etc. No segundo, além da parte administrativa do Instituto, a Cadeira de Higiene da Faculdade de Medicina ${ }^{(2)}$ e outros cursos que, por lei, deveriam ser ministrados no Instituto. No terceiro, a parte técnica do Instituto, constituída pelas seções de Epidemiologia, Bacteriologia, Psicotecnica, Parasitologia, nas quais seriam executados serviços de pesquisas que, por sua natureza, deveriam ficar separados do ensino propriamente dito. Par. te desse pavimento seria destinado a pequena dependência hospitalar, com seis leitos, considerada necessária à pesquisa.

Terreno: Locação do Prédio - Procurando reunir no Araçá o conjunto de futuros prédios da Faculdade de Medicina, Hospital da Faculdade, Clínicas Especiais, Isolamento, Profilaxia da Lepra e Medicina Legal, Paula Souza foi autorizado pelo Governo a locar o Instituto em terreno pertencente ao Estado, compreendido pela Avenida Munici$\mathrm{pal}^{(3)}$ e Rua Teodoro Sampaio, enfrente ao terreno destinado à Faculdade de Medicina.

Estrutura Metálica: Depois de rigoroso exame dos diferentes tipos de estrutura, jul- gou-se de maior vantagem, para o fim a que se destinava o prédio, o tipo "Truscon", o qual se caracterizava pela constituição especial das lajes. Paula Souza foi autorizado pelo Secretário do Interior, ofício no 1250 , de 26 de novembro de 1926 , a assinar o contrato de compra.

O pagamento fôra efetuado em Nova York pela Fundação Rockefeller, por conta do donativo referido. Em dinheiro brasileiro a compra importara em 179:007\$500, tendo sido o material adquirido e depositado no Desinfectório Central do Serviço Sanitário do Estado. Quanto à concorrência para a Construção, vencera a furma Siciliano e Silva, por despacho de 15 de março de 1927 , confirmado por Paula Souza em ofício de 8 de agosto de 1927.

Orçamento: Chegou-se a um orçamento total de aproximadamente 2.490 contos de reis.

Em 12 de dezembro de 1926, publicava "O Jornal" matéria a respeito do novo pré. dio do Instituto de Hygiene:

"A elaboração das plantas dessa nova edificação foi accompanhada, em todas as suas minúcias, pelo director do estabelecimento, que não se poupou a sacrificio de espécie alguma com 0 alto intuito de realizar uma obra integral sob todos os pontos de vista"...

. . . Annexo ao Instituto funccionará, como aliás ja funcciona actualmente, o Posto Experimental da Lepra, cuja construcção já está iniciada em pavilhão separado e o Centro de Saúde Modelo, que terão accomodaçôes muito mais amplas que as actuaes, $e$ mais próprias para os serviços a seu cargo".

Em 2 de agosto de 1928, estava Paula Souza, em Genebra como técnico da Seção

(1) Exposição de Motivos sobre o Projecto de Construcção do Novo Prédio para o Instituto de Hygiene, Accompanhada de Orçamento apresentado pela Firma Siciliano e Silva para Aquelle Fim Escolhida, Arquivo Pró-Memória, FSP/USP.

(2) As aulas para os alunos do 50 ano da Faculdade de Medicina eram ministradas na sala que então denominavam de "Sala do 5 : ano". Posteriormente, esta sala foi dividida, dando origem às salas Pedro Egydio e Borges Vieira.

(3) Atual Avenida Dr. Arnaldo. 
CANDEIAS, N. M. F. Memória histórica da Faculdade de Saúde Pública da Universidade de São Paulo 1918 - 1945. Rev. Saúde públ., S. Paulo, 18(nọ esp.): 2-60, 1984.

de Higiene da Liga das Naçðes (1927-1929). Continuava, entretanto, a acompanhar com entusiasmo a construção do novo edifício, escrevendo a Borges Vieira que, em Sá Paulo, supervisionava a obra:

“. Em addendo ao que aqui disse quanto à questāo da fachada do Instituto - quero que bem comprehendas - que só pelo facto de os edificios da Faculdade serem de um estylo - não é que faço empenho em que o nosso seja d'outro. Não necessitamos ficar presos ao adoptado pelos outros - também nada nos impede - se julgarmos mais bonito e appropriado em termos cousa semelhante.

. . . Confio em teu critério e no auxilio dos nossos engenheiros".

Nesse mesmo ano, escrevia Borges Vieira a Paula Souza, dando-the notícias sobre 0 andamento da construção do edifício e de suas complicações. Fôra apresentado o orçamento para a construção, dizendo o Secretário que era "dinheiro demais, que queriam fazer obra de luxo", recomendando portanto redução de orçamento. Preocupava-se Borges Vieira com a possibilidade de negar-lhes o Estado o auxílio prometido para complementação da obra, restando-lhes apenas, nesse caso, o auxnlio seguro da Fundação Rockefeller. Em outra carta ${ }^{(1)}$, nesse mesmo ano, comunica Borges Vieira a Paula Souza que fôra finalmente assinado o contrato entre o Governo e a Firma Siciliano e Sil. va para a construção do prédio:

"Eu já estava desanimado!"

Apesar de todos esses problemas, informa - Correio da Tarde a seus leitores no dia 17 de agosto de 1931:

"Até o fim do mez o Instituto de Hygiene estará installado no novo prédio do Araçá.
Foi essa a informaçāo que nos deu o Dr. Geraldo de Paula Souza, director desse Instituto de Sciências e lente da cadeira de Hy. giene da nossa Faculdade de Medicina".

\section{A REFORMA DO CÓDIGO SANITARIO E O CURSO DE EDUCAÇÃO SANITÁRIA}

De 1922 a 1927 foi Paula Souza encarregado da Direção Geral do Serviço de Saúde Pública do Estado. Foi quando estudou e promoveu a reforma do Código Sanitário, a qual se realizou pelo Decreto 3876 de 11 de julho de 1925 , aprovado e submetido a modificações pela Lei 2121 de 30 de dezembro desse mesmo ano ${ }^{8}$. Com ela abriram-se novos caminhos para os serviços de saúde pública do Estado de Sáo Paulo, cujas implicaçóes técnico-administrativas, por sua complexidadade, não se pretende aqui discutir. Limitar-nos-emos a registrar apenas duas das inovações propostas pela referida reforma: a primeira foi a criação da "Inspetoria de Educação Sanitária e de Centros de Saúde" e, a segunda, a inclusáo do "Curso de Educação Sanitária" no então Instituto de Higiene. $O$ Curso dirigia-se a professores primários, regentes de classes, de acordo com o artigo 460 da Lei 2121 . Seu objetivo era ministrar conhecimentos teóricos e práticos de higiene, a esses professores, para que estes os introduzissem, a partir de uma visão essen. cialmente preventiva, em Centros de Saúde e escolas.

Em 1925, durante o afastamento temporário de Paula Souza como Diretor de Serviço, o curso para alunos do sexto ano da $\mathrm{Fa}$ culdade de Medicina foi prelecionado por Sa. muel Barnsley Pessoa, assistente interino ${ }^{(2)}$.

(1) Estas duas cartas estão registradas em documento sem tf́tulo e sem data, onde se lê - "Fundamentado em Memorial fornecido pelo Prof. Paula Souza sobre o Histórico e Atividades do Instituto". Arquivo da Pró-Memória, FSP/USP.

(2) Relatório apresentado à Sua Excellencia o Senhor Doutor José Manoel Lobo, M.D. Secretário do Interior, pelo Dr. Geraldo de Paula Souza, Director do Instituto de Hygiene de São Paulo - Anno de 1925. Arquivo da Pró-Memória, FSP/USP. 
CANDEIAS, N. M, F. Memória histórica da Faculdade de Saúde Pública da Universidade de São Paulo 1918 - 1945. Rev. Satide públ., S. Paulo, 18(n⿳⺈ esp.): 2-60, 1984.

Além desse, três outros cursos foram também ministrados no Instituto de Higiene. O primeiro foi o curso para Técnicos Especialistas em Análises de Água, regido pelo substituto da Cadeira de Higiene, oferecido, como especialização, às alunas já treinadas em "Técnica Bacteriológica" pelo Instituto de Higiene. As técnicas que o concluiram foram aproveitadas, em seguida, pelo Labo. ratório de Análises do Estado. $O$ segundo foi o curso de Técnicas de Laboratório de Saúde Pública, compreendendo: Parasitologia a cargo de Samuel Barnsley Pessoa; Bacteriologia Geral a cargo de Alberto Santiago; Bacteriologia Aplicada à Higiene a cargo de Francisco Borges Vieira; Micologia a cargo de José Maria Gomes; Noçōes de Quimica e Prática de Análises Químicas Aplicadas aos Problemas Sanitários, Noções de Estatística Vital e Feitura de Gráficos a cargo de Benjamim Alves Ribeiro. Finalmente, o Curso para Educadores de Higiene, com duração de 12 meses para a parte teórico-prática, exigindo mais seis meses de exercícios de natureza prática.

No relatório apresentado por Paula Souza a José Manoel Lobo, em 1925, já constava o regulamento do Curso para Educadores Sanitários (ñ̃o mais Educadores de Higiene) a ser realizado em 1926, cujo intufto seria formar professores públicos do Estado, para que estes contribuissem à disseminação de conhecimentos de higiene entre a população e, além disso, cooperassem em campanhas pro. filáticas uma vez devidamente habilita$\operatorname{dos}^{(1) 9}$.

0 ensino desse primeiro curso compreendia nove cadeiras: 1ạ Noções de Bacteriologia aplicada à Higiene; 2 a Noçбes de Parasito. logia e Entomologia aplicadas à Higiene; 3ạ Noções de Estatística Vital e de Epidemiologia; 4ạ Higiene Pessoal, Nutrição e Dietética; 5ạ Higiene Infantil; 6a Higiene Mental, Social e do Trabalho; 7ạ Higiene Municipal e das Habitações; 8ạ Ettica, Educação e Administração Sanitária; 9ạ Princípios e Processos de Enfermagem em Saúde Pública.

A seriação das cadeiras seria a seguinte: 1 de fevereiro a 15 de março - 1 a e 2 a cadeiras; 16 de março a 15 de junho - 3ạ, 4a e 7ạ cadeiras; 15 de julho a 15 de setembro - 5a, 6a cadeiras; e 16 de setembro a 30 de novembro - 8 a e 9 a cadeiras. Previa-se que o certificado de conclusão do curso fosse conferi. do pelo Diretor do Instituto de Higiene de acordo com especificaçōes do decreto 3.876 de 11 de julho de 1925, artigo 418.

"Foi quando nós surgimos - nós as Educadoras Sanitárias. No seu entusiasmo de inovador e pioneiro Paula Souza pede, a Pedro Voss, na ocasiāo Diretor-Geral da Educação, a colaboração de professores para 0 seu programa de 'Formação da Consciência Sanitária da População'. Dezesseis são as escolhidas. Adrendam, pela primeira vez, 0 velho casarão da Baroneza de Piracicaba, na Rua Brigadeiro Tobias, em 8 de dezembro de $1925^{\prime \prime(2)}$

Comentava o "Correio Paulistano", no dia 9 de setembro de 1927, que se acabara de realizar a cerimônia da entrega de diplomas às educadoras sanitárias da primeira turma do curso do Instituto de Higiene. À solenidade haviam comparecido, além do representante do Secretário do Interior, Waldomiro de Oliveira ${ }^{(3)}$, Diretor do Serviço Sanitá-

(1) Relatório apresentado à Sua Excellencia o Senhor Doutor José Manoel Lobo, M.D. Secretário do Interior, pelo Dr. Geraldo de Paula Souza, Director do Instituto de Hygiene de São Paulo - Anno de 1925. Arquivo da Pró-Memória, FSP/USP.

(2) Discurso proferido por Maria Antonietta de Castro por ocasião das "Comemoraçōes do Jubileu de Ouro da 1a Turma de Educadoras Sanitárias no Brasil e do Jubileu de Prata da Turma de Educadores Sanitários de 1949" - Promoção da Associação dos Educadores Sanitários de Sâo Paulo, 16 de agosto de 1975 .

(3) Chefe da Inspetoria de Educação Sanitária e Centros de Saúde no período que antecedeu a F. Figueira de Mello. 
CANDEIAS, N. M. F. Memória histórica da Faculdade de Saúde Páblica da Universidade de São Paulo 1918 - 1945. Rev. Saúde públ., S. Paulo, 18(no esp.): 2-60, 1984.

rio, Pietro Martinez, pelo Diretor da Instrução Pública, F. Figueira de Mello, Chefe da Inspetoria de Educação Sanitária e Centros de Saúde, e numerosos médicos, professores, educadores e pessoas das relações das diplomandas.

A sessão fôra aberta por Borges Vieira, Diretor do Instituto de Higiene que historiando a criação do Curso de educadores sanitários, referira-se a seu valor em um meio onde todos, e principalmente professores da rede pública de ensino, precisariam voltar suas vistas para a obra indispensável pela for. mação da consciência sanitária da população. Em seguida foram entregues os diplomas, "sob as palmas de selecta assistência", às seguintes professoras normalistas: Maria Anto. nietta Mendes de Castro, Carlota Enout, Aracy Abreu, Italia de Muno, Alzira Gomes, Elizabeth de Oliveira Souza, Zulmira dos Santos Rodrigues, Maria de Lourdes Calazans Luz, Maria Graça Rodrigues dos Santos, Maria Conceição dos Santos, Edith Chaves Archer, Monica do Nascimento Silva, Geor. gina Ayrosa Azevedo, Maria Apparecida Co. le, Francisca Duarte e Silva e Carmem Borges. Após a entrega dos diplomas Maria Antonietta de Castro, em nome das educadoras, proferiu o seguinte discurso:

“. . Faz três annos hoje. Estavamos nos precalços de uma tarefa nova, de uma actividade nova, de uma actividade outra que aquella a que nos acostumaram as lides do magistério. Iamos alistar-nos em uma cruzada nova! De ânimo forte, com um enthusiasmo grande a nos borbulhar dentro d'alma, com uma vontade immensa de acertar, de fazer jus à distinç̧ão com que nos honrara o convite de entāo diretor geral da Instrucfāo Pública, o eminente educador Pedro Voss".

“. . Era a floresta a desbravar. E foi lanfando por terra os troncos annosos dos preconceitos e idéias errôneas; calcando aos pés a erva rasteira do "não paga a pena", que não tem força de subir pelos galhos altos; alijando do caminho as pedras de má vontade. .

Os professores seriam os agentes divulgadores da hygiene entre as classes populares. Era mister oriental-os para a nova missão. . . Q Que formatura "sui generis" a nossal Recebemos hoje os diplomas, já em plena actividade pratica a que nos capacitou o curso por nós realizado.

. . Dr. Waldomiro de Oliveira, à vossa escolha para paranymfo desta turma obedece a uma imposição: a da vossa bondade; $a$ do carinho, a da proficiência da vossa orientacão para com as vossas educadoras; imposição suave que se reflete na homenagem que vos prestamos.

Seja-nos também permittido relembrar, cheias de reconhecimento, a personalidade de Paula Souza, cujas palavras de encorajamento e estimulo tanto concorreram para que não esmorecéssemos na lucta. $E$ ao professor Pedro Voss, à cuja benemeréncia devemos a nossa escolha para a tarefa de que ora occupamos. $E$ ao Dr. Borges Vieira, que mais de perto seguiu nosso curso, e aos nossos lentes, Drs.: Alberto Santiago, Almeida Junior, Nuno Guerner, Garcia Braga, Dalmacio Azevedo, Samuel Pessoa, Paulo Saes, Paulo Aguiar, José Maria Gomes, Clovis Corrêa, Dra. Azalia Machado, a nossa gratidão. E ao Dr. Figueira de Mello, o emérito continuador dos trabalhos do seu antecessor, que tudo tem feito para facilitar a nossa tarefa, a expressão do nosso mais sincero agradecer".

A seguir Waldomiro de Oliveira, paranin. fo da turma, proferiu seu discurso.

A educadora Maria Antonietta de Castro (1822-1984) foi uma eminente sanitarista ${ }^{(1)}$. Logo após sua formatura, assumiu o cargo de Educadora Sanitária-Chefe da recém-criada Inspetoria de Educação Sanitária:

"Após um Curso de Especialização no Instituto de Higiene e um treino no Centro de Saúde, êi-las no próprio Centro, com inicio, em principio de 1926, nas escolas, nos domicilios. .

(1) Maria Antonietta de Castro fundou, conjuntamente com Pérola Byington, a Cruzada Pró-Infância do Estado de São Paulo. Em 1972 recebeu da Câmara Municipal de São Paulo o título de "Cidadã Paulis. tana". 
CANDEIAS, N. M. F. Memória histórica da Faculdade de Saúde Pública da Universidade de São Paulo 1918 - 1945. Rev. Saúde pribl., S. Paulo, 18(no esp.): 2-60, 1984.

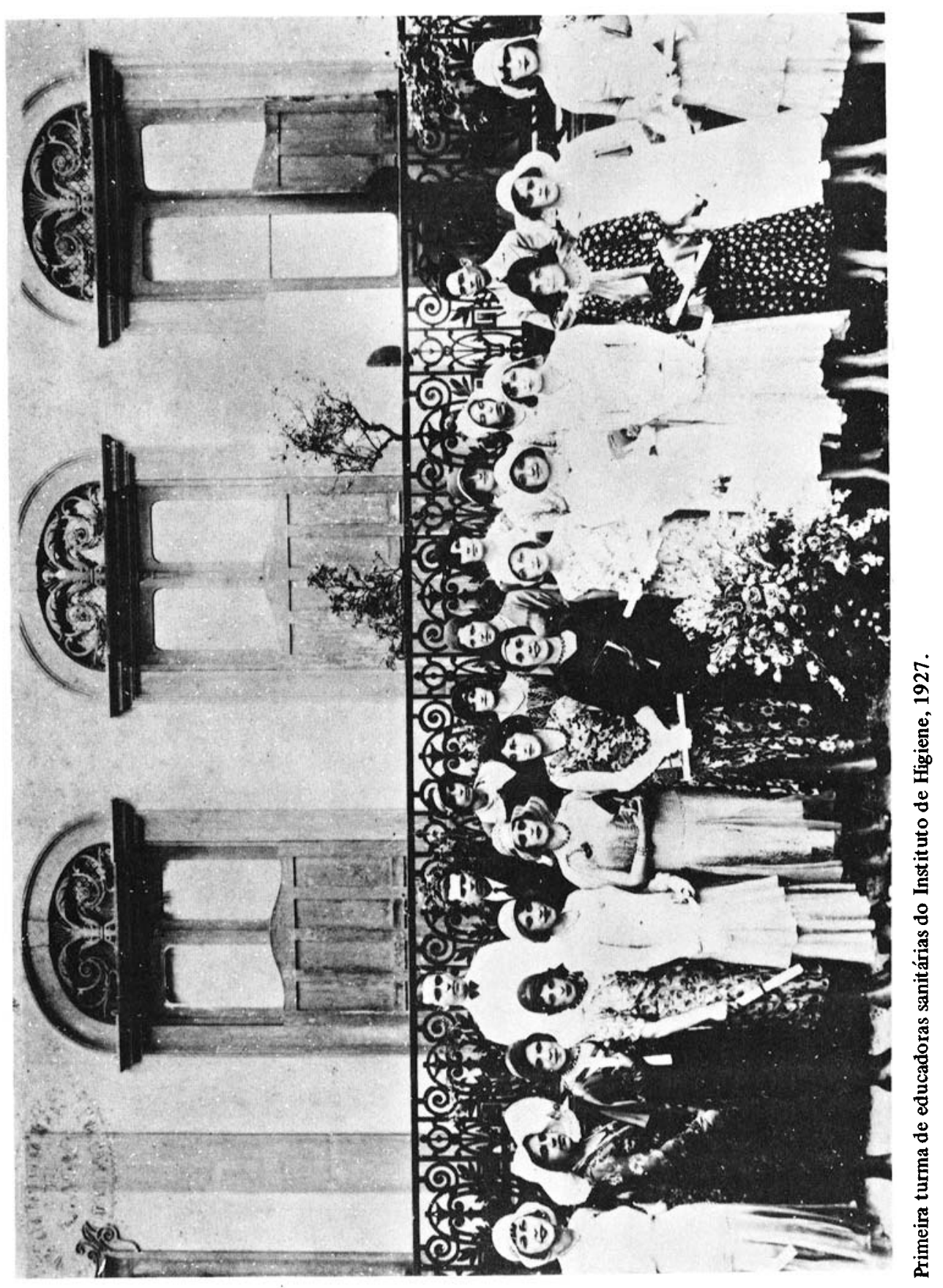


CANDEIAS, N. M. F. Memória histórica da Faculdade de Saúde Pública da Universidade de São Paulo 1918 - 1945. Rev. Saúde públ., S. Paulo, 18 (nọ esp.): 2-60, 1984.

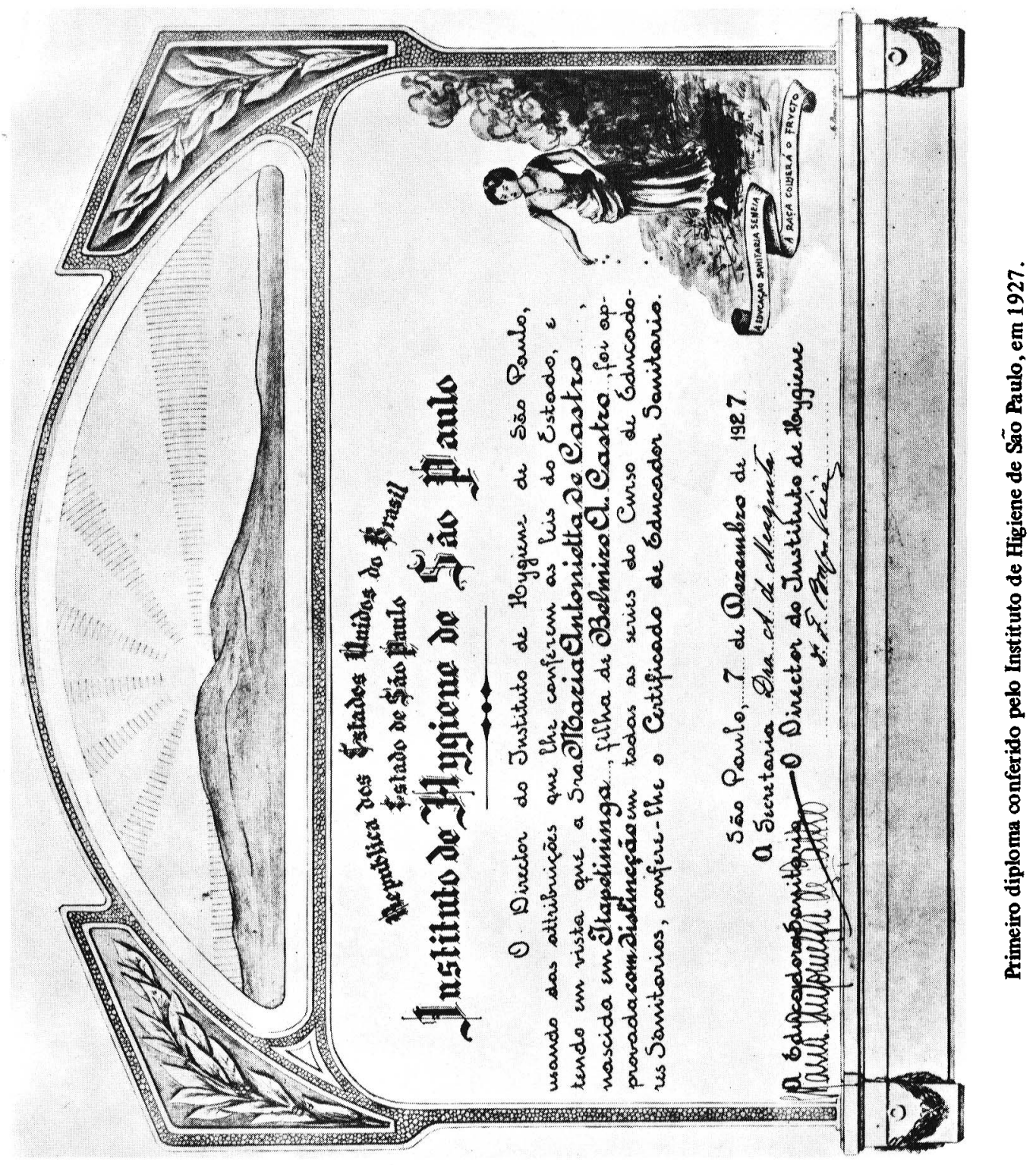


CANDEIAS, N. M. F. Memória histórica da Faculdade de Saúde Páblica da Universidade de São Paulo 1918 - 1945. Rev. Saúde públ., S. Paulo, 18(no esp.): 2-60, 1984.

... Campanhas contra a peste bubônica, contra a febre amarela, esta, em 229 cidades do interior; Cursos de Puericultura, nos Grupos Escolares; o 10 Congresso Nacional de Saude Escolar, em 1941, que reune mais de 1.000 sanitaristas, professores, psicólogos, sociólogos, de todo o Brasil e cujas conclusōes são consubstanciadas em grosso volume dos "Anais do I Congresso Nacional de Saúde Escolar".

A propósito da criação da Inspetoria de Educação Sanitária e de Centros de Saúde, comenta Rodolfo Mascarenhas que o fato de se tratar de uma proposta estranha as atividades entăo desenvolvidas pelo Serviço Sanitário, levou Paula Souza a detalhar a legislação com minúcias que mais se aproximariam a exposição de um novo Regulamento. Contra essa inovaçāo, levantou-se na Câmara dos Deputados a voz de Gama Rodrigues ${ }^{8}$ :

“. . Vem depois, sr. presidente, uma inspectoria completamente nova que é a da educação sanitária e centros de saúde. Este é um grande aparelho, completamente novo, introduzido em nosso aparelhamento sanitário. O seu fim é fazer a educação sanitária do povo, mas essa educaçāo se limita à Capital, da maneira por que esta organizada no decreto. Na minha fraca opinião é uma dessas fantasias teóricas que se podem aproximar daquilo que em tempos foram as repuiblicas escolares de triste memória".

De acordo com o depoimento de Castro, a Inspetoria não era de fato "completamente nova" uma vez que dava continuidade a esforços que haviam tido no início do século XIX.

Em 1890 surgiam as primeiras tentativas de organizar a assistência médica ao escolar nos Institutos João Kopke e Brasília Buarque, entregues então a Carlos Botelho, Sergio Meira e Arnaldo Vieira de Carvalho(1). Quatro anos depois, no Governo de Bernar- dino de Campos, surgiu pela primeira vez, no Estado de São Paulo, Código Sanitário baixado pelo decreto 233 de 2 de março de 1894. Começam a se registrar, assim, as primeiras medidas oficiais tendentes à melhoria das condiçбes da saúde escolar, por meio da fiscalização das condiçбos de iluminação, arejamento, instalação de prédios escolares e profilaxia das moléstias transmissiveis ${ }^{(2)}$.

A Lei 1245 de 30 de novembro de 1910, ao estabelecer o orçamento do Estado para 1911, autorizou o Governo a reformar o Serviço Sanitário do Estado; baseado nesta, o Governo do Estado reformou o Serviço Sanitário pelo decreto 2141 de 14 de novembro de 1911. Finalmente, a Lei 1310 de 30 de dezembro de 1911 aprovou o decreto 2141 que reorganizou o Serviço Sanitário ${ }^{8}$. Por esta lei, promulgada durante a administração de Albuquerque Lins, criou-se a Inspecção Médico-Escolar sob direção de Emflio Ribas. Reorganizada pela Lei 1541 de 30 de dezembro de 1916 - já na Diretoria Geral da Instrução Pública, sob direção de Vieira de Mello, reuniu ilustres médicos paulistas ${ }^{(1)}$.

Parece evidenciar-se, no depoimento de Castro, um ponto comum entre a Inspetoria da Educação Sanitária e de Centros de Saúde (Decreto 3876 e Lei 2121 de 1925), onde se encontravam serviços de higiene escolar, e os serviços explícitos na "Higiene Escolar", referentes à Inspecção Médico-Escolar (Lei 1310 de 1911). De acordo com Castro:

"Foi quando apareceu, pela primeira vez, em saúde pública, a Educação Sanitária e, para ministrá-la e divulgá-la, o primeiro grupo de 16 educadoras sanitárias, que estendeu a sua atuação aos Grupos Escolares Prudente de Moraes, Regente Feijo, Marechal Deodoro, John Hopke, Casa Verde e Sant'Ana, nos quais se realizaram os primeiros ensaios para

(1) Talvez o interesse de Paula Souza em contribuir para a melhoria da saíde escolar tenha decomido de seu contato com Vieira de Carvalho. Nảo há nenhuma evidência a respeito, trata-se, portanto, de mera conjetura da autora.

(2) Palestra proferida por Maria Antonietta de Castro, como Educadora Sanitária-Chefe da Diretoria do Serviço de Saúde Escolar, em Itapetininga, no dia 2 de julho de 1960. 
CANDEIAS, N. M. F. Memória histórica da Faculdade de Saúde Pública da Universidade de São Paulo 1918 - 1945. Rev. Saúde públ., S. Paulo, 18(no esp.): 2-60, 1984.

\section{a implantgção da Educação Sanitária nas escolas' $1(1)$.}

Observe-se que a atuação das novas auxiliares prendia-se náo só aos recém-criados Centros de Saude mas, tamberm, a unidades escolares.

A proposta de Paula Souza, fundamentada na utilizaçăo de Centros de Saúde e pres. supondo a inclusão de novo auxiliar de saúde, provocou, na época, algumas reaçðes contrárias. O Serviço Sanitário sob direção de Francisco Salles Gomes Filho tornaria a ser reorganizado pelo decreto 4891 de 13 de fevereiro de 1931. Com isso, a Inspetoria de Educa. ção Sanitária e de Centros de Saúde passou a denominar-se Inspetoria de Higiene Escolar e Educação Sanitária, tendo incorporado a antiga Inspeção Médico-Escolar. Passaram as educadoras sanitárias a trabalhar no Serviço de Antropometria Pedagógica, no Departamento de Educação. E este pois o serviço que após numerosas reformas, mudanças de nome e de subordinação deu origem ao Serviço de Saúde Escolar, em 1938, e, mais tarde, em 1976, ao atual Departamento de Assistência Escolar (DAE) da Secretaria do Estado da Educação. Neste se encontram hoje ilustres Sanitaristas, especialistas em Educação em Saúde na Escola, sendo justo registrar aqui o nome de Dolly Mendes.

Explica Mascarenhas que, ao se considerar os decretos 3876 de 11 de julho de 1925 e o decreto 4891 de 13 de fevereiro de 1931 como os que maior influência exerceram nas atividades sanitárias do Estado de São Paulo, torna-se evidente 0 reflexo de duas escolas com diferentes pontos de vista. Uma favorável a centros de saúde, como eixo de toda a organização sanitária; outra opondo-se à formação desse tipo de unidades sanitárias. Para Mascarenhas, o desaparecimento dos centros de saúde, originado em uma escola que via nesse tipo de unidade sanitária um "americanismo" impróprio ao nosso meio, atrazou em dezenas de anos a evolu- ção dos serviços de saúde pública no Estado de São Paulo.

\section{ALGUNS COMENTÁRIOS A PROPOSITO}

A par da criação dos Centros de Saúde que, como inovação, levantara séria suspeita na época, a inclusáo no sistema de novo auxiliar de saude, o educador sanitário, cujo perfil técnico se mostrava historicamente obscuro e impreciso na década de 20 , mesmo a nível internacional, náo poderia deixar de levantar também certo constrangimento. Além disso, propunha a realização de algu. mas atividades legitimamente atribuídas à Enfermagem ${ }^{(2)}$, o que contribuia para comprometer sua imagem.

A proposta da atuação de equipe de cará. ter multiprofissional na área da Saúde Pública em que representantes das Ciências Biomédicas, Ciências Sociais, Educacionais, Comportamentais e da Engenharia, entre outros, assumiriam na prática igual parcela de responsabilidade, estava, em seus primórdios, longe de se concretizar. A idéia começara a esboçar-se, tomando forma apenas entre observadores mais atentos e sanitaristas por vocação.

Além disso, só mais tarde, como veremos adiante, desenvolver-se-ia, com surpreendente vigor, novo campo de conhecimento técnico-científico - a Educação em Saúde Pública - em decorrência da emergência de problemas de origem comportamental, que passaram a se evidenciar na prática da Saúde Pública, tanto a nível da própria equipe técnica, quanto a nivel das populações às quais os serviços se dirigiam. Considerou-se a Educação em Saúde, portanto, campo especifico da prática da Saúde Pública. O termo surgira pela primeira vez em 1919, durante a realização do Congresso de Organização da Saúde Infantil, nos Estados Unidos. Só em 1938, contudo, um programa comunitá-

(1) Palestra proferida por Maria Antonietta de Castro, Educadora Sanitária-Chefe da Diretoria do Serviço de Saúde Escolar, em Itapetininga, no dia 2 de julho de 1960.

(2) Não existia a Escola de Enfermagem na época. Esta foi criada pelo Decreto-lei 13.040 em 31 de dezembro de 1942. 
CANDEIAS, N. M. F. Memória histórica da Faculdade de Saúde Pública da Universidade de São Paulo 1918 - 1945. Rev. Saúde públ., S. Paulo, 18(no esp.): 2-60, 1984.

rio, sob direção da educadora Lucy Morgan, acabaria por atrair a atenção a nível nacional. Este foi seguido pela apresentação de relatorio sobre "Organização de Comunidade para a Educaçăo em Saúde", elaborado por uma Comissáo da Associação Americana de Saúde Pública ${ }^{10,12}$.

Essencialmente ligada à prestação de serviços, a Educação em Saúde vale-se, entre outros, da Psicologia Social, Sociologia, Antropologia, Pedagogia (particularmente a Andragogia, educação dos adultos), Serviço Social e Comunicação. Todos esses ramos de conhecimento cientifico têm muito a ver com a ciência e arte da Educação em Saúde. Destes se originaram os princípios que, transformados em técnicas, contribuiriam para o melhor desempenho do educador de saúde nos vários níveis administrativos ${ }^{3}$. Este desenvolvimento técnico-científico que nos Estados Unidos recebeu significativo impul. so, de início com Dorothy Nyswander, Mayhew Derreberry e Lucy Morgan e, a partir da década de 70, com Lawrence W. Green, Marshall W. Kreuter, Patricia D. Mullen, Lloyd J. Kolbe, entre outros, viria a ocorrer muitos anos depois de Paula Souza propor a inclusão do novo auxiliar no sistema de atendimento médico-sanitário.

Em 1925 não fora sequer criada a Universidade de São Paulo e, quando isso ocorreu em 1934, longo período passaria antes que esta pudesse finalmente oferecer, a nível de graduação, nas várias áreas de conhecimento, programas de ensino necessários à formação básica dos candidatos graduados ao curso que, como já se disse, passou então a ser denominado de "Educação em Saúde Pública". Ora, a proposta de Paula Souza, Diretor do Instituto de Higiene e Diretor do Serviço de Saúde Pública do Estado (1922-1927), em 1925, surgira muitos anos antes. Ele próprio se surpreenderia quando, ao visitar diversas Escolas de Saúde Pública nos Estados
Unidos, em 1943, trocou idéias com Morgan em Chapel Hill ${ }^{(1)}$;

$$
\text { ‘. . quanto à Educação Sanitária, há }
$$
poucos anos, apenas Winslow havia desenvolvido esse curso na sua escola ${ }^{(3)}$. Agora a Dra. Morgan, aqui (Carolina do Norte) está desenvolvendo, há vários anos, também, essa ativi. dade. Os primeiros três "health educators" foram treinados em 1942 graças à Kellogg Foundation. Utilizam-se desses educadores para atingir a maior massa possivel de gente (Block plan ou Channel). Estão abandonando os antigos sistemas de propaganda, substituindo-o por educação tanto quanto possivel individual (há tanta gente que ou não sabe ler ou le mal). Para o curso de Public Health Educator requerem Bacharelato ${ }^{(2)}$ seja em Home Economics ou Equivalente".

Comprovando o fato de que realmente, em São Paulo, o educador era considerado auxiliar que substituia as então ausentes enfermeiras, Paula Souza pergunta a Morgan porque estavam formando educadores de saúde pública em lugares onde já se tinha acesso a enfermeiras de saúde pública. Responde-lhe esta que "as enfermeiras não fazem o que as educadoras fazem; mesmo que o pudessem fazer ná teriam tempo e isso representaria uma dispersão"(1).

Regressando ao Brasil mostra sua satis. fação em entrevista concedida ao "O Estado de São Paulo" no dia 20 de janeiro de 1944:

"no que se refere à educação sanitária, $t i$ vemos a grata oportunidade de verificar que a orientação por nós seguida em São Paulo, há 18 anos, com a criação das educadoras sanitárias diferenciadas das enfermeiras de saúde pública, tanto no seu preparo como na sua órbita de ação, vem encontrando agora o amparo dos mais distintos sanitaristas e professores, a ponto de ter sido organizada essa classe de auxiliares de saúde pública em vários setores da atividade sanitária norte-ame-

(1) Relatório da Viagem aos Estados Unidos, em 1943. Arquivo Pró-Memória, FSP/USP.

(2) O curso de São Paulo era ainda de nível médio.

(3) Trata-se de Charles-Edward Amory Winslow (1877-1957), um dos mais notáveis líderes na área da Saúde Pública nos Estados Unidos e no mundo. Autor de numerosos trabalhos, um dos quais apresenta famosa definição de Saúde Pública. 
CANDEIas, N. M. F. Memória histórica da Faculdade de Saúde Páblica da Universidade de Sáo Paulo 1918 - 1945. Rev. Saúde puibl., S. Paulo, 18(n? esp.): 2-60, 1984.

ricana. Värias Escolas de Higiene possuem cursos dessa natureza".

O Curso de Educadores Sanitários, de nível médio, foi extinto no ano de 1962 . Durante sua existência sempre se discutiu, por desinformação técnica, aspectos de atuação e função ligados à sobreposição das tarefas realizadas por parte de educadores e enfermeiros.

Em 1967 teve início o Curso de Educação em Saúde Pública, que passou a receber alunos graduados de áreas bastante diversificadas. $O$ conteúdo curricular foi submetido a graduais reformulaçóes que, como seria de esperar, demandariam a modificação das funçбes a serem exercidas no sistema de saúde nos vários níveis administrativos. Tinham passado quarenta e dois anos apos o surgimento dos educadores sanitários no Instituto de Higiene e nos Centros de Saúde. Nem este e nem aqueles continuavam os mesmos.

\section{O CURSO DE ESPECIALIZAÇÃO PARA MEDICOS}

No dia 1 9 de outubro de 1928 foi aprova. do pelo Secretário do Estado dos Negócios do Interior, Fábio de Sá Barreto(1) o "Regulamento para o Curso de Especialização em Hygiene e Saúde Pública para Médicos". De acordo com o Capítulo I, o curso visava a preparar médicos para o exercício da profissão sanitária, fornecendo ao Serviço Sanitário do Estado pessoal especializado para o desempenho dos cargos técnicos dessa administração. $O$ curso destinava-se a médicos com diplomas registrados na Diretoria Geral do Serviço do Estado, já trabalhando nesse serviço. Permitiase, contudo, que médicos estranhos a este pudessem, nฮ̃o obstante, concorrer livremente às vagas do curso que seria professado no Instituto de Higiene situado, como já se disse, na Rua Brigadeiro Tobias.
De acordo com seu Regulamento, o cur. so, de caráter técnico-prático, teria a duração de um ano, dividido em quatro trimestres de ensinos especiais, com a seguinte distribujção: 10 Trimestre - Parasitologia, Química aplicada à Higiene, Higiene Pessoal, Nutriçăo e Dietética e estágios em Serviços de Tuberculose e Venerologia; 20 Trimestre - Bacteriologia e Imunologia aplicadas \& Higiene, Estatística Vital e Epidemiologia, Administração Sanitária, e estágios na Inspetoria de Moléstias Infecciosas; 30 Trimestre - Higiene Fisiológica, Higiene Mental, Engenharia Sanitária, Higiene Pré-Natal, Pré-Escolar e Escolar. 0 quarto trimestre reservava-se para estágios em determinados Serviços e elaboração de trabalho escrito ou de relatório so. bre tema de interesse para a Higiene.

o Curso teria início em qualquer época de acordo com circunstâncias e recursos da ocasiáo. (2)

Já no dia 14 de dezembro de 1928, publicava o "Correio Paulistano" matéria com o título "Viagem de Estudos a S. Vicente":

"Chefiados pelo professor Dr. Samuel $B$. Pessoa, lente de parasitologia, irão a Säo Vicente, terca-feira, dia 18 do corrente, em carro reservado, cedido pelo Governo do Estado, os médicos que estão fazendo o curso de especialização em hygiene e saúde pública.

A partida está marcada para as 6 horas $d a$ manhã daquelle dia e o objectivo da viagem $\dot{e}$ o de visita ao serviço de malaria que se effectua na cidade mencionada. Os médicos que se acham matriculados no curso em apreço, são os seguintes: Rocha Botelho, Espirito Santo, Alfredo Cimiello, J.V. de Lucca, J. Carvalho Parreira, Luiz Araujo, Alvaro Camera, Jayme Candelaria, Amphilophio Mello, C. Pamponet Filho, Nunes Marcondes, Mendes de Castro, E. Novaes e Nogueira Martins".

Um ano depois, em 22 de dezembro de

(1) Secretário do Estado dos Negócios do Interior no período de 14 de julho de 1927 a 24 de outubro de 1930.

12) O curso de 1928 teve a duração de um ano. 
1929 , tornaria o "Correio Paulistano" a referir-se ao "Curso de Especialização em Hygiene e Saúde Pública", publicando nessa ocasião fotografia dos médicos que haviam con. cluído o curso, vendo-se no centro do grupo Paula Souza e à sua direita Borges Vieira.

No dia 18 de janeiro de 1929, informava "O Estado de São Paulo" que haviam termi. nado, a 8 do corrente, as aulas do primeiro período do curso de higiene e saúde pública realizado no Instituto de Higiene da capital sob auspícios de Fábio Barreto, Secretário do Interior, e de Waldomiro de Oliveira, Diretor do Serviço Sanitário. Informava ainda que, no trimestre letivo transcorrido, haviam sido lecionadas as cadeiras de parasitologia, por Samuel Pessoa, química sanitária, por Benjamim Ribeiro, e Higiene Pessoal, Dietética e Nutrição, por Alberto Santiago. Publicava ainda os resultados dos exames dos alunos, que constaram de provas escritas e prático-orais.

Vinha pois o Instituto de Higiene ministrando cursos especializados para médicos, a princípio irregularmente, como aquele que realizara em $1921^{(1)}$ durante a administração de Smillie e, em 1928, já com regulamento baixado pelo Governo do Estado ${ }^{16}$.

\section{PRIMEIROS TEMPOS - O TEMOR DA DESCONTINUIDADE}

Apesar dos esforços de Paula Souza e Borges Vieira em prol da criação de uma escola autônoma de Saúde Pública, certas circunstâncias ameaçavam romper a continuidade do recém-criado Instituto de Higiene. Uma delas prendia-se à própria Faculdade de Medicina, onde nem todos pareciam concordar com o desenrolar do processo.
Estava Paula Souza em Genebra onde passou um ano e meio como técnico da Seçáo de Higiene da Liga das Nações, (1927 a 1929), quando Borges Vieira, entáo Diretor do Instituto, dirigiu carta com data de 5 de setembro de 1927 a Frederick F. Russel. Este havia pleiteado, como já se referiu, a verba da Fundação Rockefeller para construção do novo edifício na entáo denominada Avenida Municipal (hoje Av. Dr. Arnaldo):

"O Dr. Paula Souza escreveu-lhe a respeito das circunstancias aqui e cada dia pequenos eventos mostram que a autonomia do Instituto está ameaçada. A Faculdade de Medicina, principalmente, quer anexá-lo $e$ isso seria o fim de nossos planos. $A$ Fundação Rockefeller, quue nos tem auxiliado até agora, poderia instruir seu representante aqui a respeito de seus desejos quanto d̀ independência do Instituto, de forma a garantir mais tarde seu desenvolvimento em uma Escola de Hygiene".

De fato, parecia ser essa uma das circunstâncias que conspirava contra a integridade do Instituto de Higiene, preocupando, em ambas as unidades, aqueles que já o percebiam como futuro órgáo autônomo da ainda inexistente Universidade de Sáo Paulo.

A respeito do relacionamento entre a Escola de Medicina e o Instituto de Higiene, ponto extremamente delicado para ambas as partes, esclarecera Wickliffe Rose, o já referido Diretor da Fundação Rockefeller' em Nova York, que este deveria permanecer ligado à Escola de Medicina, porém sem prejuí. zo de sua individualidade. Em conversa mantida com o decano da Escola de Medicina de Harvard, uma das muitas instituiçбes que também recebera verbas da Fundação para criar uma Escola de Saúde Pública, afirmara este que um Instituto dessa natureza deveria não só contar com prédio próprio, mas também com pessoal em regime de tempo integral, (2) portanto com dedicação exclusiva à Higiene e Saúde Pública. Além disso, deveria

(1) O curso de 1921 teve a duração de seis semanas. Foi frequientado por seis alunos.

(2) Cabe a Paula Souza o mérito de ter introduzido, pela primeira vez no país, o regime de tempo integral nos serviços de saúde pública. $O$ decreto 3876 de 11 de julho de 1925 apresenta no artigo 453 longa lista de cargos sob regime de tempo integral. 
CANDEIAS, N. M. F. Memória histórica da Faculdade de Saúde Pública da Universidade de St̃o Paulo 1918 - 1945. Rev. Souide pribl., S. Paulo, 18(n? esp.): 2-60, 1984.

- Instituto localizar-se na proximidade imediata da Escola de Medicina, valendo-se dos recursos humanos e materiais af existentes e, em contrapartida, colocando à disposição dela suas instalações.

Encontra-se entre os documentos pessoais de Paula Souza a seguinte afirmação:

"existisse a Universidade na ocasiäo de sua primitiva organização, não padece dúvida que a ela seria entregue esse patrimônio, a maneira do que foi feito em outros paises, onde havia Universidades organizadas'(1).

Incompreendido por muitos, procurava Paula Souza cumprir sua missão de fundar uma Faculdade Universitária de Saúde Pública, a partir daqueles princípios que, após cuidadoso estudo Welch e Rose haviam proposto. Não poderia, portanto, deixar de sonhar com a criação da Universidade de São Paulo, pressuposto básico à digna continuidade do Instituto de Higiene e na qual este se deveria, inexoravelmente, integrar. Quanto a este aspecto, cumpre aqui registrar idéias por ele expressas em "O problema do ensino universitário", discurso proferido em reunião realizada no Rotary Club de São Paulo, no dia 19 de julho de $1929^{(2)}$ :

"Já lembramos estar fora de debate a questão da oportunidade de criação de universidades no Brasil. São acordes todas as pessoas ouvidas até hoje em proclamar a sua necessidade. Uma vez aceito este ponto, dúvidas poderiam surgir quanto à questão da localização de organismos universitários, aqui ou acolá

Não cremos, todavia, que objeç̃o alguma pudesse se interpor à lógica, à insofismável vantagem da localizaçāo de uma universidade nesta Capital.

$1-E^{E}$ portanto oportuna a organizaçđo de uma universidade em Sáo Paulo;

2 - Esta teria por fim primordial a formação das elites de que tanto necessitamos e que devem existir em todo pais que pretende ter individualidade própria.

3 - $A$ simples reunião de escolas técnicas superiores ou de institutos vários, por ventura existentes, não basta para se considerar organizada uma universidade. Formaria, assim, no máximo, um complexo administrativo, de discutivel vantagem, mas não um verdadeiro centro estimulador de esforços e de alta cultura".

Cartas e documentos referentes à decada de 30 continuam a refletir a apreensáo de Paula Souza pelo futuro do Instituto de $\mathrm{Hi}$ giene. Em dezembro de 1930, manifesta seu temor quanto ao pensamento do novo Diretor da Faculdade de Medicina e Cirurgia, Sergio de Paiva Meira Filho (22 de dezembro de 1930 - 14 de julho de 1932). Diplomado na Universidade de Genebra, onde fôra assistente de anatomia do Prof. Laskouski e assistente de Cirurgia do Prof. Girard foi, tanto quanto Vieira de Carvalho, um dos mais ardorosos e eminentes colaboradores na organização da Faculdade de Medicina de Sáo Paulo. Durante sua gestão, como Diretor da Faculdade de Medicina, inaugurou-se o atual edifício da Faculdade ${ }^{6}$.

Preocupado quanto à sua posição como Diretor, comenta Paula Souza em carta de 19 de dezembro de 1930 dirigida a Frederick L. Sc $\boldsymbol{r}_{\boldsymbol{r}}$ ur, representante da Fundação Rockefeller do Brasil, então residindo no Rio de Janeiro:

"O Dr, Ernesto Souza Campos deixou a direçäo da Escola Médica de Säo Paulo. Outro Diretor será designado, provavelmente o Dr. Sergio de Paiva Meira, Professor de Cinurgia. Como uma das maiores necessidades em Sáo Paulo é realmente a falta de instalações hospitalares temo que o Governo planeje utilizar o edificio do Instituto para um hospital. Durante a visita que the fiz on-

(1) Documento sem data e sem título, marcado apenas com o número 16, Arquivo da Pró-Memória, FSP/ USP.

(2) A cópia da Ata publicada, contendo o discurso de Geraldo Horácio Paula Souza, foi gentilmente cedida pelo Rotary Club de Sáo Paulo a pedido do Dr. Durval Rosap Borges. 
CANDEIAS, N. M. F. Memória histórica da Faculdade de Saúde Publica da Universidade de São Paulo 1918 - 1945. Rev. Saúde publ., S. Paulo, 18(n? esp.): 2-60, 1984.

tem, o Dr. Neiva ${ }^{(1)}$ procurou me convencer que não sabia qual a verdadeira situação do Instituto de Hygiene, pedindo-me que lhe escrevesse para lhe dizer quais sâo os objetivos do Instituto de Hygiene e sua orientação e que tipo de trabalho se realizou nos últimos anos!! Parece-me portanto que vocé poderia me fazer o favor de escrever uma carta que poderia ser mostrada ao Dr. Neiva dizendo-lhe exatamente qual é a posição des. te Instituto e de como a Fundação Rockefeller fez uma doação de 1.500.000\$000 ao Governo de São Paulo para a construção de uma Faculdade de Hygiene e de como essa doaçẫo foi feita, não como no caso da Faculdade de Medicina, da verba da Medical Education Boards Funds, mas do International Health Board Funds, para que fique perfeitamente claro que essas instituiçōes são independentes uma da outra e seus objetivos distintos. Parece ser conveniente também lembrar que essas escolas existem em muitos outros paises, além da Faculdade de Medicina, e que são absolutamente indispensáveis para o treinamento adequado de pro. fissionais da saúde, visto que uma instruçāo assim tão especializada nẫo pode ser satisfatoriamente dada durante o curso usual de Medicina".

No dia 23 de dezembro de 1930 , respondeu Soper à angustiada solicitação do Diretor do Instituto de Higiene. Vale a pena registrar aqui, por seu valor histórico, o teor dessa correspondência:

"Na fase de organização porque passa São Paulo neste momento, e possivel como é que o Dr. deseje informar oGoverno sobreos fins do Instituto de Hygiene de São Paulo, a sua orientação, e a parte que representava a Fun. dação Rockefeller na sua criaçāo, julguei conveniente the remeter algumas informações a esse respeito.

Em 18 de fevereiro de 1918, o Governo de São Paulo firmou um termo de ajuste por 5 anos como International Health Board pa- ra a organização de um departamento de hygiene anexo d̀ Faculdade de Medicina de São Paulo, comprometendo-se o Governo Paulista a fornecer o prédio adaptado ao funcionamento do Departamento, com acomodações necessárias aos trabalhos de laboratório, preleções, etc. A Fundação Rockefeller se obrigaria a fornecer a quantia necessária para o equipamento do Instituto, calculada em cerca de 10.000 dolares; os fundos necessários à manutenção da mesma durante aquele periodo; duas bolsas de viagem para estudos de hygiene e saúde pública a dois médicos brasileiros; e a cessão de um técnico americano para Chefe de Departamento, com dois auxiliares brasileuros. Assim foi até 1923, quando o Governo do Estado opinou pela dilatação do acordo para mais dois anos, o que foi aceito por ambas as partes.

Assim nasceu o Instituto de Higiene. Em 1922, o Dr. F. Russel, Diretor do International Health Board, após uma visita ao Instituto, já tendo imimeras provas de grande interesse pelo progresso da instituição, fez ao comitê a proposta da doação de 1.500 contos para a construção de um prédio próprio, adaptado a suas múltiplas funções, ao seu desenvolvimento e aos seus fins.

.. . tal instituiçāo como as que existem em outros paises, são absolutamente indispensaiveis para o treinamento adequado dos médicos sanitaristas, pois que as Escolas de Medicina existentes nđ̄o fornecem instruçāo satisfatória em seus cursos usuais a tais especializações."

Além desse, outros incidentes iriam perturbar o Diretor e Vice-Diretor do Instituto de Higiene no decorrer do agitado ano de 1930. Enviou Waldomiro de Oliveira, Diretor do Serviço Sanitário no período de 18 de agosto de 1927 a 24 de outubro de 1930 , ofício a Fábio de Sá Barreto, Secretário do Interior (14 de julho a 24 de outubro de 1930), em que se lia ${ }^{(2)}$ :

(1) Arthur Neiva foi Secretário do Estado dos Negócios do Interior no período de 5 de dezembro de 1930 a 13 de fevereiro de 1931. Foi também o primeiro Diretor do Instituto Biológico.

(2) A cópia do ofício encontra-se no Arquivo da Pró-Memória, FSP, USP. Registra apenas o ano (1930). 
CANDEIAS, N. M. F. Memória histórica de Faculdade de Saúde Pablica da Untversidade de São Paulo 1918 - 1945. Rev. Saride publ., S. Paulo, 18(n9 esp.): 2-60, 1984.

"Com o intuito de melhorar as installaçöes do Serviço Sanitário e suas Secções e, ao mesmo tempo, supprimir despezas com aluguéis de prédios, mandei organizar uma relação dos prédios occupados pelo Serviço Sanitário, com especificação dos aluguéis que são pagos por cada um e das datas em que findam os contractos de locação.

. . . Não sendo pequena a despeza desses aluguéis com que arca o Thesouro, seria medida econômica, beneficiadora das finanças do Estado, encontrar-se um meio de eliminar esse dispêndio.

Parece-me que esse problema se resolveria, cedendo à Directoria do Serviço Sanitário $e$ algumas de suas dependências, a accomodações no prédio da Avenida Municipal, cuja construcção se ultima e é destinada ao Instituto de Hygiene".

Existiam pois circunstâncias que, periódica e até concomitantemente, perturbavam as atividades dos responsáveis pelo Instituto de Higiene. Também durante a Revolução de 1930 , fora este invadido por "bisonhas tropas do Sul"(1). Além disso cortes e reduçбes de verbas interrompiam periodicamente o prosseguimento da construção do prédio', apesar das obrigações assumidas pelo Governo em relação à Fundação Rockefeller.

Ameaças dessa natureza repetem-se no transcorrer do tempo. No dia 12 de janeiro de 1931, dirige Paula Souza carta ao Secretário da Segurança Pública que, arbitraria. mente, decidira aquartelar um batalhão no prédio ainda em construção do Instituto de Higiene.

\section{"Senhor Secretairio"}

Accusando o recebimento de ordem telephonica de V. Excia. afim de entregar ao 39 batalhäo de policia do Estado o prédio em construçāo, do Instituto de Hygiene, tomo a liberdade de fazer algumas ponderaf̧ões.

Pelo que V. Excia. teve a oportunidade de me informar, a estadia, muito provisória do referido batalhäo em nosso prédio, seria de duas a tres semanas apenas.
Soubemos, entretanto, agora, que pretende aquella unidade ali se instalar por espaço de 6 a 8 mezes, tendo já transportado todo material e mobiliario, archivos e biblioteca, parecendo portanto, não se tratar de uma breve estadia.

Lembro a $V$. Excia. que o prédio em questão constitue obra de collaboração internacional na qual se acha vivamente compromettido o Governo do Estado perante a Fundação Rockefeller. A paralizaçāo das obras do Instituto já causou desagradável impressāo no seio daquella benemérita corporação, e o desvirtuamento, embora provisório dos fins a que se destina aquelle prédio, certamente é fadado a causar a mais dolorosa impressão".

No dia seguinte publicava o "Diário Nacional":

"Os soldados aquartelados no Instituto de Hygiene farão o policiamento do Jardim América".

Como registram estes dados, os anos de 1930-1931 haviam sido particularmente penosos para o Diretor e Vice-Diretor do Instituto de Higiene, assim como para seus colaboradores. A construção do edifício estava quase terminada e isso, naturalmente, não deixava também de representar ponderável riscn 1 ornava-se assim urgente efetuar a mudança do casarão da Rua Brigadeiro Tobias para a Av. Dr. Arnaldo. Apesar disso o efeito das verbas exíguas fazia-se sentir, como comprova carta de W.A. Sawer da Fundação Rockefeller, em 7 de janeiro de 1931, lamentando a interrupção das obras do edifício destinado à Escola.

Assim se expressou Paula Souza em entrevista concedida ao "Correio da Tarde" no dia 3 de abril de 1931:

"Um esforço a mais por parte do governo viria completar essa obra. Como sabemos, está em construç̧ão ao lado da Faculdade de Medicina, à Av. Dr. Arnaldo, o novo prédio do Instituto de Hygiene, que recebeu

(1) Expressão utilizada por Paula Souza no discurso proferido por ocasião da homenagem póstuma prestada a Borges Vieira no 30 ? dia de seu falecimento. 
CANDEIAS, N. M. F. Memória histórica da Faculdade de Saúde Pública da Universidade de São Paulo 1918 - 1945. Rev. Saúde públ., S. Paulo, 18(nọ esp.): 2-60, 1984.

da Fundą̧ão Rockefeller uma dotação para a sua edificação mediante compromisso formal do Governo do Estado em doar o sufficiente para que ele seja terminado.

De todas as escolas de hygiene creadas pe. la Fundação Rockefeller, é a nossa a de menor vulto. Recebeu, como as demais, donativos na mesma occasiōo, isto é, em 1925. Todas já se acham edificadas e funccionando há longo tempo. Só a nossa permanece ainda em obras.

... Todos os demais paizes entraram com sommas quasi que identicas às recebidas. São Paulo, que recebeu 188.000 dollares, teria ainda que fazer um pequeno esforço. Que o faca e gaste 60.000 dollares mais.

Estou certo que essa importância virá, para não ficarmos mal collocados perante os demais paizes que receberam, como Säo Paulo, doaçōes da Fundação Rockefeller."

Não obstante tais contratempos, permitiria a persistência de Paula Souza que o Instituto de Higiene fosse transferido para o novo edifício, embora incompleto, em agosto de 1931. Nessa altura este já se havia transformado, veremos a seguir, em Escola de Higiene e Saúde Pública.

\section{A ESCOLA DE HIGIENE E SAUDE PUBLICA}

Pouco antes de Arthur Neiva (1880-1943) se afastar da Secretaria do Estado dos Negócios onde permaneceu pouco mais de um ano ${ }^{(1)}$, decidiu realizar importantes reformas em alguns dos departamentos sujeitos àquela Secretaria, entre os quais se encontravam o Serviço Sanitário, o Ensino Normal, o Instituto Butantan e o Instituto de Higiene. Comentava o "Correio da Manha" em 25 de janeiro de 1931 que embora as duas primeiras reformas já houvessem sido assinadas pelo Interventor Coronel João Alberto Lins de Barros, as duas últimas, assinadas por
Arthur Neiva, continuavam a aguardar, não obstante, a assinatura daquele: "as causas dessa não aprovação por parte do interventor, parecem ser a presença de falhas e lacunas nesses dois departamentos, decorrentes da pressa com que foram reformados, quando da saída do Sr. Arthur Neiva da Secretaria do Interior. A serem verdadeiras essas informaçס̃es que o "Correio da Tarde" colheu em fonte autorizada, não foi dos mais felizes o trabalho do Sr. Arthur Neiva no seu penúltimo dia de secretariado."

Pouco depois o Decreto 4917 de 3 de março de 1931 transformou a Secretaria do Estado do Interior em Secretaria do Estado de Educação e Saúde Pública ${ }^{8}$. Era Diretor do Serviço Sanitário do Estado, naquela ocasião, João de Barros Barreto ${ }^{(2)}$ que, há algum tempo, vinha sentindo a necessidade de criar um órgáo capaz de superintender, de modo mais integrado, as atividades de saúde pública do Estado. A partir dessa perspectiva, estabeleceu o referido decreto como dependência da nova Secretaria o Departamento de Saúde, cujo Diretor Geral passaria a superintender o Serviço Sanitário, o Instituto Butantã, o Instituto Pasteur, o Hospital do Isolamento, o Instituto Bacteriologico, a Assistência a Psicopatas e, finalmente, o Instituto de Higiene. A este propósito, informava o Diário Nacional no dia 5 de março de 1931:

"O Sr. Interventor Federal despachou hontem, pela primeira vez, com o secretario interino da pasta da Educação e Saúde Publica, antiga Secretaria do Interior, ora a cargo do Sr. Oliveira Coutinho ${ }^{(3)}$, levando ao que soubemos, entre outros, os decretos reorganizando o Instituto de Hygiene e o Butantan"...

De fato, a este seguir-se-ia o Decreto 4955 de 1 Q de abril de 1931. Já se referiu que, poucos anos antes, no dia 1 9 de outubro de 1928, o Secretário do Estado dos Negócios

(1) Secretário do Estado dos Negócios do Interior no período de 5 de dezembro de 1930 a 13 de fevereiro de 1931.

(2) Diretor do Serviço Sanitário do Estado no perfodo de 6 de março de 1931 a 26 de julho de 1931.

(3) Secretário do Estado dos Negócios do Interior do período de 3 a 5 de março de 1931. 
CANDEIAS, N. M. F. Memória histórica da Faculdade de Saúde Páblica da Universidade de São Paulo 1918 - 1945. Rev. Saude públ., S. Paulo, 18(no esp.): 2-60, 1984.

do Interior, Fábio de Sá Barreto ${ }^{(1)}$, para atender às necessidades do ensino especializado de higiene para médicos, havia aprovado o "Regulamento para o Curso de Especialização em Higiene e Saúde Pública", a ser ministrado no Instituto de Higiene de São Paulo:

"O curso de especializaç⿸̃o em hygiene e saude puiblica visa preparar médicos para o exercicio da profissão sanitária, fornecendo ao Serviço Sanitário do Estado pessoal especializado para o desempenho de cargos técnicos dessa administração (artigo 19)."

Este foi o estabelecimento reformado pelo decreto 4955 de 1 o de abril que, uma vez assinado por Lins de Barros, propunha a reorganização do Instituto de Higiene, trans. formando-o definitivamente em Escola de Higiene e Saúde Pública do Estado, subordi. nado à Secretaria da Educação e Saúde Pública. Vejamos o teor desse decreto:

'O Coronel João Alberto Lins de Barros, interventor Federal no Estado de São Paulo considerando que, para o bom desempenho das funcçōes sanitárias, 0 engenheiro, $o$ médico e outros profissionais necessitam de estudo especializado; considerando que $o$ actual Instituto de Hygiene, tal como se acha, não corresponde a sua primordial finalidade educativa, para a qual foi creado; considerando que o seu apparelhamento para 0 ensino especializado de hygiene pode ser encetado sem augmento de despesa;

\section{DECRETA}

Artigo 1? O Instituto de Hygiene de São Paulo, criado pelo Governo do Estado em collaboração com a Fundação Rockefeller, $e$ officializado pela lei no 2018, de 26 de Dezembro de 1924, fica reorganizado nos termos do presente decreto.

Artigo 29 O Instituto de Hygiene de $S$. Paulo, que é a Escola de Hygiene e Saide Pública do Estado e subordinado à Secretaria da Educaçāo e da Saúde Pública, tem por fim:
1) O ensino de Hygiene e Saude Pública por meio de cursos regulares $e$ outros de emergência, servindo ao aperfeiçoamento e habilitaçāo technica para funç̧ōes sanitárias. .."

Cabia aos técnicos que por ali se diplomassem, "preferência, em igualdade de condiçбes, para o provimento nas Repartiçōes do Estado nos cargos técnicos iniciais de suas especialidades."

Criara-se assim núcleo formador de nova carreira. Para esses eminentes ideólogos sanitaristas, como se observa, a saúde pública, por sua problemática multidimensional, não poderia contar tão somente com a especia. lização de médicos. Estes representavam im. portante componente na prática da saúde pública, porém apenas parte de um todo e - que se pretendia era a formação de uma equipe multiprofissional de saúde pública ${ }^{10}$. Além de se tornar irrazoável, por isso, locali. zar esse tipo de ensino em uma escola médi. ca, parecia-lhes agora imprescindivel considerar o reconhecimento oficial dos diplomas ali expedidos.

O Decreto 4955 de 1 9 de abril precisaria ser posteriormente alterado, veremos adiante, em decorrência de três importantes decretos referentes à legislação federal do ensino superior, assinados pelo Presidente Getúlio Vargas e por Francisco Campos 7,11 . O primeiro foi o decreto 19.851 , de 11 de abril de 1931, que regulamentou o estatuto das universidades brasileiras. $O$ segundo foi 0 decreto 19.852 , da mesma data, que dispôs sobre a organização da Universidade do Rio de Janeiro. Finalmente, o decreto 20.179 de 6 de julho de 1931 dispôs sobre a equipara. çăo dos institutos de ensino superior mantidos pelos governos dos Estados e sobre a inspecção de institutos livres para efeito de reconhecimento oficial dos diplomas por êles expedidos. Tornava-se portanto necessário que os regulamentos destinados a presidir os cursos já ministrados fossem exarados e que os já existentes, como o do curso para médi-

(1) Secretário do Estado dos Negócios do Interior no perfodo de 14 de julhō de 1927 a 24 de outubro de 1930. 
CANDEIAS, N. M. F. Memória histórica da Faculdade de Saúde Páblica da Universidade de São Paulo 1918 - 1945. Rev. Saúde públ., S. Paulo, 18(nọ esp.): 2-60, 1984.

cos, fossem revistos, não só com vistas a adaptá-lo a nova legislação do Instituto, mas também para que seus trtulos se tornassem válidos em todo o país. Isso exigiu mais dez anos de esforços.

Mas voltemos, por questão de ordem, ao Decreto Estadual 4955 de 1931. Explicava Paula Souza em entrevista concedida ao Correio da Tarde, no dia 3 de abril, que o motivo da referida demora fôra o extremo cuidado e a atenção das pessoas que nos últimos meses haviam se empenhado no estudo da reorganização do Instituto de Higiene. Desde a época de José Carlos Macedo Soares ${ }^{(1)}$, informava seu Diretor, sob cuja administração se realizara o primeiro projeto de reorganização, até os últimos dias da ad. ministração de Arthur Neiva, haviam se concretizado os pontos mais essenciais da reforma. Durante a administração de Edmundo Navarro de Andrade ${ }^{(2)}$, graças aos conhecimentos técnicos e ao prestígio de Barros Barreto, procurava-se conceder a Sáo Paulo uma organização à altura das demais congêneres no país. Explicava Paula Souza na referida entrevista:

"na forma actual, o que se fez em principio de importância foi, sobretudo, melhor definir e delimitar as actividades do Instituto de Hygiene, dando-lhe caracteres puramente de escola de hygiene moderna. Ahi, sobretudo foram de grande valor as luzes juridicas do Prof. Sampaio Doria. . . Esta pois consolidada no Brasil, a sua primetra escola de hy. giene, com feicão mais ampla que os anteriores cursos de aperfeiçoamento sanitúrio. Já era tempo, em nosso meio, de caracterizar perfeitamente a profissto sanitúria como dividida da prótica médica corrente."

\section{A FILOSOFIA DE ENSINO}

Em relação aos alunos de medicina e de engenharia, assim se expressara Paula Souza em entrevista concedida ao "Correio da Tarde" em abril de 1931.

'Si por um lado, nos cursos médicos cada vez mais se diffunde, no espirito dos estudantes, a idéia prophylactica e social da medicina, visando tornal-os mais aptos a cooperar com as autoridades sanitárias, nem por isso se pensa possuirem os novos médicos, assim orientados, competência para o cabal desempenho de funçôes especializadas, de efficiente organização de saúde puiblica.

. . . Por melhor preparo, entretanto, que recebam os médicos em escola moderna, carecem-lhe elementos que só uma ulterior especialização lhes poderia dar, para o bom desempenho de missóes attinentes à saúde pública. O mesmo se pode dizer do engenheiro, já que os cursos regulares dessa profissão necessitam de outros complementares para os habilitar no concernente à technica sanitária.

Contudo, tanto o médico não especializado como o engenheiro commum têm sido chamados ao desempenho de funç̧ōes sanitórias, verificando-se que nem sempre a sua boa vontade ou os seus esforços se vêem coroados de êxito correspondente.

... Rosenau ${ }^{(3)}$, o grande professor americano, a esse respeito, em 1915, assim se expressava: 'Causa dó a observafão dos vãos esforços e perda de energia, tempo e dinheiro, por parte dos Sanitaristas, que tenham conhecimentos imperfeitos e incompletos das sciências de que depende o seu trabalho'. Sobre esse mesmo assumpto, no memorial apresentado ao governo, diziamos que se poderia, estudando as demais actividades que comporta a vida nacional, dizer que, em grande parte, a difficuldade de solução dos problemas ou das crises que nos affectam, repousa na falta absoluta do preparo adequa. do daquelles aos quaes estão confiados os

(1) Secretário do Estado dos Negócios do Interior no período de 25 de outubro de 1930 a 4 de dezembro de 1930.

(2) Secretario da Educação e Saúde Pública no perf́odo de 5 de março de 1931 a 5 de maio de 1931.

(3) Trata-se de Milton J. Rosenau, famoso higienista da Universidade de Harvard e autor do livro intitulado "Medicina Preventiva e Saúde Pública". 
CANDEIAS, N. M. F. Memória histórica da Faculdade de Saúde Pública da Universidade de São Paulo 1918 - 1945. Rev. Saúde públ., S. Paulo, 18(n? esp.): 2-60, 1984.

trabalhos de responsabilidades technicas.

Ainda somos um paiz de amadores em quasi tudo, embora a complexidade dos nossos problemas já seja de natureza a desafiar os próprios profissionaes."

Preocupava-se o Diretor da nova escola, explicitamente, não apenas com um curso de aperfeiçoamento para médicos, o que se tornava evidente no teor do Decreto 4955, mas com o desenvolvimento historico de núcleo formador de uma nova carreira $^{(1)}$ :

"Este Instituto, que é a Escola de Higiene do Estado, inaugura hoje o seu primeiro curso de especialização em higiene e saúde puiblica.

... Nâo se trata apenas de curso de aperfeiçoamento para médicos interessados no assunto, senão de um nuicleo formador de uma nova carreira.

... Se não mais se admite o médico pouco versado em assunto de medicina preventiva, tão complexas se apresentam com freqüência as questões de saúde pública, que 0 melhor curso das Faculdades de Medicina é insuficiente para assegurar cabal competência para o perfeito exercicio das funçōes sanitärias. Um sem numero de estudos essenciais ao sanitarista fogem à preparação do médico.

Rosenau pondo em relevo o complexo de noçōes que a higiene moderna envolve e a necessidade de o sanitarista conhecer os pormenores dos problemas que lhe são afeitos, disse ser preciso:

"que de tudo saiba alguma coisa e do que cuida especialmente conhefa tudo".

Ora o curso médico abrange apenas parte daquele "tudo" de que necessita saber alguma coisa e, por vezes, muito pouco daquilo que precisa "tudo conhecer".

Embora filiada à biologia e intimamente ligada à medicina clinica, aborda a higiene freqüentemente o campo da engenharia, quando nāo do direito e da sociologia; da educação serve-se como instrumento valioso, utilizando-se de seus métodos. Tem enfim uma individualidade própria que se revela tanto na apreciação teórica do conjunto de conhecimentos de que se compōem, como no exercício prático da profissão que dela deriva.

Winslow - já em 1912 - na American Health Association - insistia - no que tem tido quem lhe aprove a idéia - de que nem só aos médicos deveria ser aberta a carreira sanitária, mas a todos que possuindo cultura tivessem também conhecimentos particulares do assunto. Daqui então: prefiro o homem que conhece saúde pública $e$ não conhece medicina, ao que conhecendo a medicina não conheça saúde pública.

Estamos em que, sobretudo para o nosso paiz, $\dot{a}$ parte os engenheiros sanitários que formam profissão distinta, o sanitarista convem que seja médico, tanto mais primitiva a regiâo em que deva actuar - mais solicitada a sua dupla qualidade de médico e de higienista.

Médico apenas, entretanto, não se conclui capaz para o desempenho das funçōes especificas que os serviços de hygiene modernos exigem de seus funcionários. Hemenway dos mais acatados autores em matéria de legislaçāo e administraçāo sanitárias afirma que durante muito tempo, nos Estados Unidos, pensava-se ser todo médico competente para opinar sobre assuntos de higiene $e$ dirigir repartições sanitárias, porém não existe um clínico sobre quinhentos que conheça os rudimentos de saúde pública moderna, o preparo, a prática, idéias e objetivos do bom médico, sendo inteiramente diversos dos de uma autoridade sanitária ideal.

Courmont, o eminente mestre de Lyon, apreciando a complexidade dos problemas que envolvem a conservação de saúde puiblica diz ser a 'higiene uma sciência social que ultrapassa os limites da medicina'.

... Creio que assim fica bem evidente poderem e deverem coexistir as duas preocupa-

(1) Manuscrito de Paula Souza. Arquivo da Pró-Memória, FSP/USP. 
CANDEIAS, N. M. F. Memória histórica da Faculdade de Saúde Pública da Universidade de São Paulo 1918 - 1945. Rev. Saúde públ., S. Paulo, 18(no esp.): 2-60, 1984.

fōes - que nāo săo antagônicas mas complementares - a da difusáo dos conhecimentos de hygiene e de saúde pública - em todas as camadas sociais - e sobretudo a incentivação dos conceitos sanitários no conjunto de conhecimentos dos médicos - e a concomitante especialização de médicos para fins de saúde puiblica".

Os comentários de Paula Souza permitem entender, como se observa, a linha de pensa. mento que fundamentara a proposta de criação da Escola de Higiene e Saúde Pública. Dera-se portanto outro importante passo, treze anos após a criação do Laboratório de Higiene.

\section{A EQUIPARAÇÃO DA ESCOLA}

0 Decreto 6283 de 25 de janeiro de 1934 , assinado pelo então Interventor Federal no Estado de Sáo Paulo, Armando de Salles Oliveira e seu Secretário de Educação e Saúde Pública, Christiano Altenfelder Silva, criou finalmente a Universidade de Săo Pau10. Nessa altura havia no Estado, além de outros de menor tradição, quatro centros de ensino bem definidos: a Faculdade de Direito, a Escola Politécnica, a Faculdade de Medicina e a Escola Agrícola Luiz de Queiroz. De acordo com o Artigo 3 ? do Título II, passaram a fazer parte da Universidade de Sto Paulo os seguintes institutos oficiais: Faculdade de Direito, Faculdade de Medicina, Faculdade de Farmácia e de Odontologia, Escola Politécnica, Instituto de Educação, Faculdade de Filosofia, Ciências e Letras, Instituto de Ciências Econômicas e Comerciais, Escola de Medicina Veterinária, Escola Superior de Agricultura e Escola de Belas Artes.

Além destes, concorriam para ampliar o ensino e a ação da Universidade, de acordo com 0 Artigo 40, o Instituto de Higiene, o Instituto Biológico, o Instituto Butantan, o Instituto Agronômico de Campinas, o Instituto Astronômico e Geográfico, o Museu de Arqueologia, História e Etnografia, o Ser- viço Florestal e outras instituições de caráter técnico e científico do Estado?.

Assim se localizava então o Instituto de Higiene em termos da recém-fundada Universidade de Sáo Paulo. Poucos dias antes de sua criação, entretanto, já se desencadeara processo que visava a pleitear novo regula. mento para o Curso de Especialização em Higiene e Saúde Pública para médicos ${ }^{(1)}$. Cumpre aqui examinar o sentido desta reivindicação, tendo como ponto de referência os decretos federais de 1931. Vejamos em que medida exigiam estes que os regulamen. tos destinados a presidir os cursos já minis. trados fossem exaurados, como se comen. tou anteriormente. De acordo com o Artigo 108 do Decreto 19.852 de 11 de abril de 1931 que dispõe sobre a organização de Universidade do Rio de Janeiro", "enquanto não se organizar a Escoia de Higiene e Saúde Pública, que fica criada por este Decreto, funcionará como dependência da $\mathbf{F a}$. culdade de Medicina do Rio de Janeiro o curso de especializaçáo em higiene e saúde pública, o qual visará o preparo dos médi. cos que se destinam à funçōes sanitárias e dos que nela já se acham investidos. Parágrafo único - Aos profissionais, que obtiveram o certificado de conclusáo do curso de especialização em higiene e saúde pública, será assegurado o direito de preferência absoluta para o provimento de cargos federais de função sanitária, efetivos, interinos, contratados ou em comissão, excetuados os que exigem competência especializada e também os de direito de serviço, cujo provimento dependa de confiança do Govêrno."

Em 15 de janeiro de 1934, portanto dez dias antes da criação da Universidade de São Paulo, enviou o Interventor Federal no Estado de Sáo Paulo ao Ministério da Educação e Saúde Pública documentos referentes ao reconhecimento, a nível federal, da Escola de Higiene e Saúde Pública ${ }^{(1)}$. Esperava-se que o Ministro determinasse as devidas providências em termos do Decreto no 20.179

(1) Ensino Superior - 19.12.34 - App. Unanim. 20.12.34.

a) A. Lacombe - Copia. Arquivo da Pró-Memória, FSP/USP. 
CANDEIAS, N. M. F. Memória histórica da Faculdade de Saúde Publica da Universidade de Såo Paulo 1918 - 1945. Rev. Saúde públ., S. Paulo, 18 (n9 esp.): 2-60, 1984.

de 6 de julho de 1931, anteriormente ao qual já vinha aquela Escola funcionando. Este Decreto dispóe sobre a equiparaçáo de institutos de ensino superior mantidos pelos Governos dos Estados para efeito do reconhecimento oficial dos diplomas por eles expedidos?.

Dos documentos apresentados constava entro ampla exposição destacando que por existir em São Paulo organização oficial, o Instituto de Higiene, criado pela Fundação Rockefeller em colaboração com o Governo do Estado, oficializado em 1924 e que constituia, conforme o Decreto Estadual no 4955 de 10 de abril de 1931, a Escola de Higiene e Saúde Pública do Estado, pleitea. va-se seu reconhecimento de acordo com o Artigo 17 do Decreto Federal, 20.179 de 6 de julho de 1931, por preencher as condiçōes ali exjgidas. Diz o Artigo 17 do referido Decreto que "os atuais institutos de ensino superior mantidos pelos Governos dos Estados ficam dispensados da verificaçáo a que se refere 0 artigo 39 , podendo desde logo entrar nas prerrogativas do reconhecimento oficial dos diplomas e da equiparação, nos termos deste decreto, uma vez requerida a respectiva concessão" ". Complementava a exposição que, por ocasião do decreto de 6 de julho, já a Escola de Higiene realizava cursos gerais e de especialidades destinados à população em geral, a estudantes da Cadeira de Higiene da Faculdade de Medicina e a especialização de técnicos sanitaristas, médicos, engenheiros e educadores sanitários. Passava-se depois a argumentar que a Escola correspondia, de acordo com dispositivos do artigo 29 do decreto federal de 6 de julho de 1931 , aos requisitos exigidos para sua equiparaç⿸丆o a estabelecimentos congêneres da Uniáo. 0 ofício de 15 de janeiro de 1934, assinado pelo Interventor de Sáo Paulo, e os documentos acima referidos foram enviados, ainda em janeiro, por despacho do Ministro, ao Conselho Nacional de Educação(1), o qual só se pronunciaria a respeito em dezem. bro desse mesmo ano. Enquanto isso o Inter- ventor Interino do Estado de São Paulo enviara 20 Ministro, em aditamento ao ofício de 15 de janeiro, exemplar do Diário Oficial do Estado onde fora publicado o decreto 6674 de 19 de setembro de 1934, dando no vo regulamento não mais à Escola mas ao Curso de Especialização de Higiene e Saúde Pública para médicos, que funcionava na Escola de Higiene e Saúde Pública de São Paulo para efeito de reconhecimento do referido curso, conforme Lei Federal. De acordo com o artigo 10 do Capítulo 1, "os cursos de Hygiene e de Saúde Publica, constantes deste regulamento, serão de ensino seriado e visam a especialização dos médicos em geral e da. quelles que se acharem investidos de cargos públicos relacionados em assumptos de hygiene e saúde pública." Este decreto era mais amplo do que a proposta da Univer. sidade do Rio de Janeiro, visto que esta se dirigia apenas a médicos, enquanto $o$ artigo 19 do decreto estadual afirmava: "além do curso regular para médicos de que trata este regulamento, poderáo ser admitidos à matrícula, numa ou em algumas disciplinas, os profissionais que nellas queiram especializar-se, ficando as condiçøes de matrícula a juízo do diretor do estabelecimento." Destacava-se, portanto, a importância nđo apenas do.preparo de médico sanitarista, fração de um todo, mas de um grupo multiprofissional de sanitaristas, pressuposto básico da prática da Saúde Pública.

Voltemos entretanto ao assunto em pauta, o curso de especialização para médicos. Referia o parágrafo único do artigo 108 do Decreto Federal, como já se disse, que profissionais que obtivessem certificado de con. clusão do curso de especialização em Higiene e Saúde Pública pela Escola do Rio de Janeiro teriam o direito de preferência absoluta para cargos federais. Para o curso de São Paulo se solicitava assim a equiparação aos dos institutos federais congêneres. Existindo pois, como então se demonstrava, curso oficial de especialização de Higiene e Saúde Pú. blica na Faculdade de Medicina do Rio de

(1) O Conselho Nacional da Educação foi criado pelo Decreto Federal 19.850 de 11 de abril de 1931 . Vide Lei 174 de 6 de janeiro de 1936. 
CANDEIAS, N. M. F. Memória histórica da Faculdade de Saúde Pública da Universidade de São Paulo 1918 - 1945. Rev. Saúde públ., S. Paulo, 18 (nọ esp.): 2-60, 1984.

Janeiro, seria este o curso congênere ao qual se teria de equiparar o da Escola de São Pau1o. Após municioso estudo, propós a Comissão encarregada desse parecer que, feitas algumas modificações, poderia ser deferida, nos termos do artigo 17 do decreto 20.179 de 6 de julho de 1931 , a solicitação do reconhecimento constante do processo feito pelo Interventor de São Paulo. Esse decreto dispõe sobre a equiparação dos institutos de ensino superior mantidos pelos governos dos Estados, assim como sobre a inspeção dos institutos livres para efeito do reconhecimento oficial dos diplomas por êles expedidos": "Artigo 19 - Serão oficialmente reconhecidos como válidos para o exercício profissional no território da República, observadas quaisquer outras disposições administrativas federais ou estaduais, os diplomas expedidos pelos institutos de ensino superior, congregados ou não em Universidade, mantidos pelos Governos dos Estados nas condições prescritas por este decreto.

Vejamos agora as modificações introduzidas pelo Decreto 6674 de 1934 no decreto de $1931^{(1)}$, enviado em aditamento ao referido ofício de 15 de janeiro:

Capitulo I - Objeto dos Cursos - Introduzia-se-lhe, à semelhança do curso de Higiene e Saúde Pública Federal, parágrafo assegurando aos diplomados preferência no preenchimento de cargos técnicos de função sanitária.

Capitulo II - Da matrícula - Referia-se à preferência absoluta natural de que deveriam gozar, para efeito de matricula, profissionais já no exercicio de funçōes públicas de caráter sanitário. Esses funcionários poderiam ser comissionados junto à Escola durante o periodo do Curso.

Capitulo III - Dos cursos - Com o objetivo de tomar o curso, para efeito de equiparação, de acordo com o federal, o qual exigia parte básica a ser realizada no Instituto Oswaldo Cruz, a Escola de Higiene e Saúde Pú- blica de São Paulo se propunha, como unidade didática completa, a ministrar o curso básico, ou preliminar, equivalente ao programa do referido Instituto, dispensando do mesmo os candidatos que já o houvessem freqüentado.

Assim se apresentava o curso para preparo de médicos sanitaristas em 1934. Porém, apesar dos esforços dispendidos para reconhecimento oficial de diplomas e equiparação a nível federal, isso só viria a ocorrer sete anos depois de iniciados esses esforços, com o Decreto 7198 de 20 de maio de 1941:

'Em 1941, após exame cuidadoso das atividades didáticas do Instituto de Higiene, em processo iniciado desde vários anos antes, foi o curso de médicos sanitaristas oficial. mente reconhecido por decreto do Sr. Presidente da Republica, sendo seus diplomas, para todos os efeitos, equiparados aos do Curso que funciona no Rio de Janeiro, como dependência do Departamento Nacional de Saride"16.

Quanto aos educadores, o Decreto 6321 de 28 de fevereiro de 1934 estabelecia novo regulamento para o curso de Educadores Sanitários:

'O Doutor Armando de Salles Oliveira, Interventor Federal no Estado de São Paulo, usando das atribuiçóes que the confere o decreto federal $n \varphi 19.398$, de 11 de novembro de 1930; e considerando que a experiência tem aconselhado algumas modificações na organização de Educadores Sanitários, decreta:

Artigo 19 - O Curso de Educadores Sanitários, criado pela lei $n$ ? 2121, de 30 de dezembro de 1925, art. 460, a cargo do Instituto de Hygiene de Säo Paulo, visa ministrar a professores diplomados conhecimentos theorico-práticos de hygiene, no intuito de concorrer para a formação da consciência sanitária do povo e cooperar com os senviços de saúde puiblica nas campanhas prophylati-

(1) Instituto de Higiene de S. Paulo. Escola de Higiene $\in$ Saúde Pública do Estado. Modificaçðes propostas ao Regulamento atual para o Curso de Especialização em Higiene e Saúde Pública para médicos. Abril de 1934. Arquivo da Pró-Memórịa, FSP/USP. 
CANDEIAS, N. M. F. Memória histórica da Faculdade de Saúde Pública da Universidade de São Paulo 1918 - 1945. Rev. Saúde públ., S. Paulo, 18(no esp.): 2-60, 1984.

cas". Seguem-se considerações a respeito da admissão ao curso, freqüència, notas de aprovação e certificado de conclusão do cur. so.

Já em 1934, portanto nove anos após a sua criação, começara-se a realizar reformas gradativas no curso de Educação Sanitária. Este seria interrompido em 1962. Em 1967, criou-se o Curso de Educação em Saúde Pública, o qual passou a exigir diploma univer. sitário, tornando-se, portanto, de nível superior. Tinham passado quarenta e dois anos desde o primeiro curso e a proposta de di. ferenciar educadores sanitários de enfermei. ras de saúde pública, tanto em preparo quanto em campo de ação, já desde 1944 vinha recebendo o amparo dos mais eminentes sanitaristas $^{(1)}$.

\section{INCORPORAÇÃO Ȧ UNIVERSIDADE DE SÃO PAULO}

No início de 1938 o Instituto de Higiene correu, mais uma vez, sério risco. Passou o Governo, representado por Francisco Salles Gomes Júnior, então Secretário da Educação e Saúde Pública do Estado (21/12/1937 a $23 / 4 / 1938$ ), a estudar a possibilidade de realizar o que então se denominou de "fusão dos laboratórios do Serviço Sanitário".

- A este respeito, publicava o Diário da Noite, no dia 28 de janeiro de 1938, matéria sobre "A Fusão dos Institutos Scientíficos de S. Paulo":

"Conforme foi noticiado, o secretário da Educaçẫo e Saúde Püblica, sr. Francisco Salles Gomes Júnior, nomeou há dias uma Comissão da qual fazem parte os Srs. Humberto Pascale, inspetor geral do Serviço Sanitario, no interior; Nicolau Rosseti, médico-auxiliar do Instituto de Hygiene, e J.P. de Carvalho Lima, director do Instituto Bacteriológico, incumbindo-a de estudar a possibilidade de fusäo dos institutos scientíficos paulistas que passariam a formar um único estabelecimento scientifico de alta pesquisa.
A reportagem do Diário da Noite procurou ouvir o titular da Educação sobre as razões que teriam motivado esse plano de uniformização dos núcleos de pesquisas scientificas, em São Paulo.

... - Trata-se de uma iniciativa da qual resultam duas grandes $e$ apreciáveis vantagens. Primeiro, uniformiza-se o serviço de pesquisas scientificas e, em segundo lugar, é uma medida de alcance econômico.

Com a fusão dos institutos scientificos num só estabelecimento desapparece essa situação de multiplicidade existente em São Paulo. Assim, qualquer assumpto que se queira estudar sob o ponto de vista scientifico são muitos laboratórios, ao mesmo tempo, que se encarregam disso. Exemplo frizante temos dessa moléstia que chamam de febre amarela sylvestre. Está sendo estudada pela commissäo especial chefiada pelo $\mathrm{Dr}$. Aragão: os Institutos de Hygiene e Bacterio. lógico também pesquisam.

. . . O Rio de Janeiro, nesse ponto, collo. cou-se na vanguarda. Lá todos os institutos de pesquisa médica passaram para o Instituto de Manguinhos.

. . O Serviço Sanitário - prossegue o Dr. Salles Gomes - tem tres institutos: o Bacteriológico, o Serviço de Leite e o da Alimentaçāo Pública. Elle também seria attingido por essa uniformização. Outros estabelecimentos são: o Instituto Butantan, Pasteur e o Instituto de Hygiene.

... - E quanto tempo durarão os estudos? Isso faz pensar que vae levar ainda mezes.

Sorrindo, retruca o titular da Educação: - Você já me conhece. Isso de muito tempo não é commigo. Gosto de fazer as cousas no minimo tempo possivel. Estamos trabalhando e em menos de um mez já teremos os estudos necessários para a fusão dos nossos institutos de alta pesquisa scientifica".

Cartas e documentos testemunham a inquietação pela qual passou o então Diretor do Instituto de Higiene. A primeira de que

(1) "Diário da Noite", 19 de janeiro de 1943: A Medicina Preventiva determinou grandes transformações no campo da higiene. 
CANDEIAS, N. M. F. Memória histórica da Faculdade de Saúde Pública da Universidade de São Paulo 1918 - 1945. Rev. Saúde públ., S. Paulo, 18(no esp.): 2-60, 1984.

se tem conhecimento foi dirigida a José Carlos de Macedo Soares, Interventor paulista, no dia 14 de fevereiro de 1938:

\section{"Amistoso Saudar}

. . . Conforme o amigo talvez esteja informado pela leitura dos jornais, o Governo estuda a possibilidade da fusão de vários laboratórios do Serviço Sanitário; inclui entretanto entre eles o Instituto de Higie ne, de funçōes inteiramente diversas e completamente dedicado ao ensino. Contra essa reunião do Instituto aos demais laboratórios é unânime o parecer de quantos desapaixonadamente têm estudado a questâo.

o Conselho Técnico da Faculdade de Medicina já se manifestou a respeito nesse sentido; da mesma opiniāo é o Reitor da Universidade, Professor Reynaldo Porchat. Estou inibido de fazer sentir diretamente esse ponto de vista ao Secretário da Educação e Saúde, com quem não mantenho relações pessoais, embora tenha sido o mesmo, meu secretário no Serviço Sanitário. . .

... Nenhum professor sequer da Faculdade de Medicina é membro da referida Comissão. Acresce ainda que o Instituto de Higiene é uma criação do Governo de São Paulo em conjunto com a Fundafão Rockefeller. Esta fez ao Estado doaçōes com o fim explicito de servir ao ensino e incluido o Instituto na fusão projetada, ficaria o mesmo desvirtuado da finalidade de doaçāo".

Dois dias depois de enviar essa carta ao Interventor de Săo Paulo, escreve Paula Souza a Galeno de Revoredo, médico, gaúcho, residente no Rio de Janeiro nessa época, muito provavelmente pessoa com influência junto ao então Presidente Getulio Vargas:

"Remeto-lhe, por intermédio do nosso colega e amigo Dr. Edmundo Vasconcellos, uma cópia da "representação" lida por mim hoje, perante a Congregação da Faculdade de Medicina. Após a leitura da minha "exposiçāo", toda a Congregação acorde, resolveu. unanimente, dirigir por intermédio do Reitor da Universidade, uma moção ao interventor paulista, pedindo-lhe que retire o Instituto de Higiene do projeto de fusão dos laboratórios; $e$ que as modificaçōes que por ventura venha a passar o Instituto, sejam resultado de estudo da referida Congregaçāo, não devendo de forma alguma ser alterado o espirito das doações e a intenção de seus fundadores, nunca vindo a ter outro destino ou emprego, o prédio, instalaf̧ões, etc., do Instituto.

Muito grato ficaria, se o colega, com seus bons oficios, conseguisse que viesse do Rio para o nosso interventor, qualquer determinação nesse sentido. Seria de todo o interesse que tal medida viesse sem demora, pois o atual Secretário da Educação está apressando a projetada e inconveniente 'fusẫo".

De fato, nesse mesmo dia, a pedido do catedrático de Higiene, reunira-se a Congregação da Faculdade de Medicina da Universidade de São Paulo, com a presença de vinte e dois professores, para que esta se pronunciasse a respeito da proposta que visava a incluir o Instituto de Higiene no estudo que então se fazia na Pasta da Educação, tendente à "fusão de laboratórios". Paula Souza envia, então carta a Porchat, Reitor da Universidade de Sáo Paulo ${ }^{(1)}$ :

“. . Compreende-se que se reunam em laboratórios espaços de finalidade semelhante: os de diagnóstico, de preparo de sôro $e$ vacinas, de análises bromatológicas, de leite, ou dos serviços de lepra, malária, etc., todos sob a guarda e direção do Serviço Sanitário, responsável pela execuçāo de medidas diretamente de ordem sanitária.

Instituiçōes de ensino não podem formar ao lado dessas; sua finalidade é outra e não fazem duplo emprego. As primeiras cuidam dos problemas imediatos a serem resolvidos pelas autoridades competentes; as segundas do ensino e preparo de sanitaristas e do estudo de problemas de ordem mais acadêmica, de possivel interesse imediato, porém não obrigatoriamente sujeitas a soluções rápidas.

(1) A data não consta na cópia da carta. Arquivo Pró-Memória, FSP/USP. 
CANDEIAS, N. M. F. Memória histórica da Faculdade de Saúde Pública da Universidade de Săo Paulo 1918 - 1945. Rev. Saude pribl., S. Paulo, 18(n? esp.): 2-60, 1984.

... O que, em última análise, fatalmente se verificaria caso se fizesse a inclusāo do Instituto de Higiene no grupo a fundir, seria apenas a encampação do prédio, instalações e material do Instituto, desviados de suas funçōes precipuas, deixando nosso organismo universitário amputado e retrogradado em relação a outras instituiçōes, mesmo nacionais".

Solicitava-se ao Reitor da Universidade que, na cátedra da Faculdade de Direito, no Conselho Universitário e no Conselho Nacional de Educação, vinha firmando o valor de suas virtudes cívicas e morais, considerasse a moção aprovada por unanimidade em respos. ta à proposta apresentada por Pinheiro Cin. tra, Aguiar Pupo e Jayme Pereira, assim consubstanciada: pedir ao Interventor Federal que excluísse o Instituto de Higiene, prolon. gamento da Cadeira de Higiene da Faculda. de, do projeto de fusão de laboratórios de Saúde Pública; solicitar que fosse ouvida a Congregação da Faculdade antes de se promover qualquer reforma ou alteração na estrutura e organismo do referido Instituto; exprimir desagrado a medidas tendentes a ocupar o prédio e a dispor ou reduzir material e equipamentos indispensáveis ao ensino da Cadeira de Higiene, por qualquer repartição que não fosse dependente da mesma:

"A Congregação está certa de que $S$. Excia., também Professor Universitário, acolherá esse apelo da Faculdade de Medicina, como a maior homenagem à confiança que deposita no seu elevado espirito de magistrado".

Em 11 de março, dirige-se o Diretor do Instituto de Higiene a Soper, Diretor da Fundação Rockefeller no Brasil:

... "Aparentemente entra em latência o golpe preparado. Sei todavia, por várias fontes, que o projeto continua a ser estudado de forma a, no papel, respeitaram-se na aparência a integridade $e$ finalidades do Instituto, que entretanto passaria a sofrer as modificações que lhe quisessem introduzir.

Consta que é coisa para breves dias, mas como tudo se passa em segredo, ignoro as particularidades. $O$ que transpira pode não corresponder $\dot{a}$ verdade; indica entretanto que não deram por finda a questão.

. . . Peço ao amigo que não descanse para que por meio de subterfügios näo venha a ser mutilada ou disvirtuada esta obra de 20 anos de colaboração".

Em 12 de março de 1938 torna a escrever a Galeno de Revoredo:

... Os planos atuais de tocar nos Institutos são apenas roupagens para coonestar uma única intenção, que é atingir de qualquer forma a organização do Instituto de Higiene.

Uma vez sustado o primitivo plano de fusão, que seria a aniquilação completa e definitiva do Instituto de Higiene, uma nova fórmula foi encontrada para atingir o mesmo fim a prazo mais longo. . a fórmula encontrada seria a seguinte: mantidos como tais os Institutos, permaneceriam os mesmos como entidades distintas, porém sob uma direçāo geral única, que limitaria as atribuiçōes de cada um a sua vontade. Outra particularidade do projeto é que um determinado projeto, nāo dispondo de meios em certo setor, poderia requisitar o necessário e ocupar dependências, material e pessoal de outro Instituto. Cada Instituto ficaria entretanto com o seu Diretor, mero cumpridor de ordens $e$ da orientação que outros lhe quisessem impor. No caso particular do Instituto de Higiene, que é dirigido pelo Professor da Cadeira de Higiene e verdadeiro prolongamento desta, ficaria de fato sob duas direções: a da Faculdade e a do novo diretor do laboratório, donde inevitáveis conflitos. Aos poucos o material e pessoal que possui seria distribuido por outras repartições e assim mutilado nada poderia produzir. Suas finalidades de ensino seriam completamente desvirtuadas, pois passaria a simples dependência do Serviço Sanitürio. $O$ que se projeta, viria em última análise, a significar a mesma cousa que a fusão primitivamente intentada."

Resta perguntar que estratégia poderia ser utilizada para garantir a transformação do Instituto de Higiene em uma unidade mais de acordo com os princípios então aceitos 
CANDEIAS, N. M. F. Memória histórica da Faculdade de Saúde Pablica da Universidade de Sזo Paulo 1918 - 1945. Rev. Saride públ., S. Paulo, 18(no esp.): 2-60, 1984.

pelo seu corpo docente, defendendo-o assim contra certas modalidades de absorção. Uma solução seria subordiná-lo novamente à $\mathrm{Ca}$ deira de Higiene, do qual se desligara, como já se viu, por ocasiáo da oficialização do Instituto de Higiene, Lei 2018 de 26 de dezem. bro de 1924. E foi isso que aconteceu.

O Decreto 9279 reorganizou o estabelecimento, incorporando-o à Universidade de Sro Paulo e subordinando o à cadeira de Higiene da Faculdade de Medicina:

" $O$ Doutor Adhemar Pereira de Barros, Intenventor Federal no Estado de Säo Paulo, usando de suas atribuiçôes legais e considerando as vantagens de dispor o ensino da $\mathrm{Hi}$ giene de um Instituto onde possa desenvolver, em todos os seus graus, o máximo de eficiência;

Considerando que o Instituto de Higiene de São Paulo já é, por força do Decreto $\mathrm{Fe}$ deral no 39, de 3 de setembro de 1934, instituiçāo complementar da Universidade de São Paulo;

Considerando que o Governo Federal, em caso idêntico, relativo ao Instituto de Puericultura, o incorporou sob a direção do Catedrático de Puericultura e Clínica da Primeira Infäncia da Faculdade de Medicina, d̀ Universidade do Brasil, nos têrmos do Decreto-Lei n? 98 de 23 de dezembro de 1937;

Considerando que o Governo do Estado criou, em colaboração com a Fundação Rockefeller, o Instituto de Higiene, e que esta circunstância requer se mantenha 0 espirito que presidiu a essa iniciativa, principalmente no tocante à intima ligaçāo com a Faculdade de Medicina sem prejuizo dos fins que lhe são proprios,

Decreta:

Artigo 19 - Fica incorporado à Universidade de São Paulo o Instituto de Higiene de São Paulo, reorganizado pelo Decreto no 4.955, de 10 de abril de 1931, como Escola de Higiene e Saude Publica, subordinando-se, diretamente, à cátedra de Higiene da Faculdade de Medicina, da mesma Universidade".

0 artigo 2, Parágrafo 19, deste Decreto mostrava claramente a principal finalidade da Instituiçăo: " $O$ ensino da Higiene do cur. so normal de ciências médicas; o de especia. lização e de aperfeiçoamento em Higiene e Saúde Pública para diplomados em cursos superiores da Universidade e outros destinados ao aperfeiçoamento e à habilitação técnica para funçб̄es sanitárias". Cumpre ressaltar que, de acordo com o decreto 9279, os diplomados nos cursos do Instituto teriam preferência para o provimento, nas repartiçбes públicas do Estado, dos cargos técnicos de sua especialidade.

A propósito do Decreto 9279 assim se manifestou Fred F. Soper em carta enviada a Paula Souza no dia 20 de maio de 1938:

"Tendo estudado juntos a possibilidade de ser reorganizado o Instituto de Higiene de Sāo Paulo, anexando-o novamente à Faculdade de Medicina, como representante que sou da Fundação Rockefeller no Brasil, pediria, afim de nāo ser alterada fundamentalmente a organizaçāo para a qual desde a creação contribuio a Rockefeller, fosse respeitados alguns pontos essenciais.

Quando em 1918 a Fundação se dispoz a cooperar com o Governo do Estado para o estabelecimento do ensino da Higiene em São Paulo, quiz dar-lhe oportunidade ampla de desenvolvimento, contribuindo melhor assim para o preparo e treinamento de sanitaristas.

No seu entender, bem como no do saudoso Professor Samuel Taylor Darling, primeiro Diretor do Instituto, deveria este manter de um lado a mais intima ligação com a Faculdade de Medicina, conservando, de outro, ampla possibilidade de desenvolver atividades mesmo a ela estranhas; ter, em uma palavra, sua individualidade distinta, seu pessoal inteiramente devotado ao estudo $e$ ensino da Higiene, completamente imbuido de espirito próprio.

Por isso foi que quando da elaboração dos planos para as novas construções, tanto o $\mathrm{Dr}$. Pearce como o Dr. Russell entenderam dever ficar separados, embora muito próximos, os edifícios, destinados à Escola Medica e ao Instituto de Higiene, e os trabalhos deste último inteiramente subordinados ao Professor 
CANDEIAS, N. M. F. Memória histórica da Faculdade de Saude Pública da Universidade de São Paulo 1918 - 1945. Rev. Soúde públ., S. Paulo, 18(nọ esp.): 2-60, 1984.

da matéria da Faculdade de Medicina. Aliás, os recursos fornecidos pela Fundafãa provieram de duas fontes distintas: a divisäo da "Medical Education", para a Faculdade, $e$ a "International Health Board" para o Instituto, convergindo no aperfeiçoamento, em São Paulo, tanto do ensino da medicina como do ensino da Higiene.

Funcionou originalmente o Instituto, creado como um anexo da Faculdade, prolongamento da Cadeira de Higiene, como o desejavam seus fundadores, mais amplo que outros departamentos fundamentais e tendo sempre liberdade administrativa.

Si o Instituto fosse novamente anexado d̀ Faculdade, deveria ser-lhe assegurado não só todo o ensino destinado ao pessoal superior sanitarista e pessoal auxiliar de saude pública, como ainda serem mantidos orçamentos distintos, usufruindo a faculdade do uso de verbas independentes do resto da Escola Médica. Manter-se-ia assim para o Instituto o mesmo paralelismo com a Faculdade, que presidio a sua creação.

O Instituto de Higiene nunca poderá exercer a influencia necessária enquanto o Serviço Sanitario não exigir diploma dos candidatos às vagas nesse Serviço".

Temia pois o representante da Fundação no Brasil que, uma vez anexada à Cadeira de Higiene da Faculdade de Medicina, perdesse a Escola sua individualidade e, com ela, a primazia quanto à formação de sanitaristas e pessoal auxiliar.

Não admira que estivesse Paula Souza preocupado com o desenrolar do processo e com o possível desvirtuamento da institui. ção. Pouco depois, o Decreto 9437 , de 22 de agosto de 1938, tratou realmente da organização do Serviço de Laboratório de Saú. de Pública do Departamento de Saúde, justificando assim suas apreensōes. Com isso passaram os Institutos Butantă, Bacterioló. gico e Pasteur a integrar o que entáo se desig. nou de Serviço de Laboratório de Saúde Pú. blica.

Para Mascarenhas" "esta foi mais uma tentativa de centralização dos laboratórios de saúde pública fadada ao fracasso, pelos seguintes motivos: (a) não houve uma completa reorganização dos laboratórios, com uma divisáo mais racional dos mesmos. Cada laboratório conservou a sua individualidade, a sua organização anterior, as suas instalaçóes próprias e os seus prédios próprios. 0 que mudou foi apenas o rótulo; (b) a chefia do novo serviço foi localizada no longinqüo bairro do Butantã, identificando-se com o Instituto do mesmo nome. Os Institutos Bacteriológico e Pasteur continua. ram na cidade. Isto veio. aumentar ainda mais a burocratização dos serviços administrativos desses dois órgáos; (c) os diretores do Instituto Bacteriológico e Pasteur esta. vam acostumados a se entenderem direta. mente com o Diretor Geral do Serviço Sanitário e a tradição fez com que a tendência dos mesmo fosse de uma aproximação maior com essa antiga subordinação".

Tudo parece indicar que a tentativa de incluir a Escola de Higiene e Saúde Pública no que entáo se denominou de "fusáo dos laboratórios do Serviço Sanitário" e os temores que a proposta despertara em seu $\mathrm{Di}$. retor tenham contribuído para sua incorporação à recém-criada Universidade de Ş̃o Paulo.

Submetida novamente à Cadeira de Higiene da Faculdade de Medicina de onde se originara, mas cuja estrutura atual não mais justificava, apresentava agora a Escola perfil jurídico que lhe permitiria reivindicar, em um segundo tempo, sua transformação em instituto universitário autônomo. Vinte anos tinham decorrido desde a criação do Laboratório de Higiene da Faculdade de Medicina.

O Decreto 9273 da mesma data, 28 de junho de 1938, organizou o Serviço dos Centros de Saúde da Capital com a finalidade de orientar e superintender os serviços dos Centros de Saúde da Capital, no sentido não somente do desenvolvimento dos seus trabalhos, como também da articulação de suas funçত̃es com a Diretoria do Departamento da Saúde. De acordo com esse decreto ca. beria ao Centro de Saúde, como unidade co. letiva e polivalente em suas funçбes, centra. lizar em seu distrito sanitário todas as ativi. 
CANDEIAS, N. M. F. Memória histórica da Faculdade de Saúde Pública da Universidade de São Paulo 1918 - 1945. Rev. Saúde pribl., S. Paulo, 18(no esp.): 2-60, 1984.

dades sanitárias compatíveis com sua organização. Este teria como finalidades principais educação sanitária, imunização contra as moléstias transmissiveis, tratamento dos focos, suscetível de ser feito em dispensários, pesquisa deste e de outros focos em geral; além disso, exame médico periódico, inculcação de hábitos sadios e melhoria das condições sanitárias.

O Decreto 9341 de 20 de julho de 1938 organizou, por sua vez, o Serviço do Interior do Estado que passou a ser composto de Di. retoria com sede na Capital do Estado e de Centros de Saúde a serem instalados no in. terior do Estado.

Obviamente, pressupunha isto o treinamento de técnicos na Escola de Higiene e Saúde Pública, não só para ocupar cargos nessas "unidades coletivas e polivalentes", como também em outras instituições recém-organizadas ou a serem futuramente organizadas por esses e outros dispositivos legais.

Outros importantes decretos, que certamente mereceriam estudo mais profundo, marcaram os anos de 1938 e 1939. Limitar-nos-emos, contudo, a referi-los brevemente. O Decreto 9906 de 6 de janeiro de 1939 criou o Centro de Estudos sobre Alimentação naquela Escola. Tres meses depois o Decreto 10.090 de 4 de abril passou a exigir curso de especialização para o provimento dos cargos iniciais de médico-sanitarista e de educador sanitário. No dia 19 de julho desse mesmo ano, o Decreto 10.387 deu novo regulamento ao Curso de Educação Sanitária e o Decreto 10.440 de 21 de agosto alterou a redação de alguns artigos. O Decreto 10.617 de 24 de outubro de 1939 criou curso destinado à formação de nutricionistas. Tal como ocorreu com o Curso de Educação Sanitária, também este seria interrompido, dando lugar ao Curso de Saúde Pública para Graduados em Nutrição. Outros surgiriam, posteriormente, concretizando os anseios dos sanitaristas da Escola no sentido de preparar técnicos oriundos de várias, porém entrelaçadas áreas de conhecimento.
$\mathrm{Na}$ longa evolução do Instituto de Higiene de 1918 a 1941 , duas datas se revestiram de especial significado em sua evolução histórica: em 1924, quando recebeu oficialmente a designação de Escola de Higiene e Saúde Pública do Estado, designação revigorada, como se viu, em 1938; em 1941 quando o Governo Federal, após exame da documentação existente e de inspecção de sua capacidade didática, expediu o decreto 7198 reconhecendo o Curso de Saúde Páblica mantido pela Escola de Higiene e Saúde Pública da Universidade de Sáo Paulo, baseado no Decreto-Lei 421 , o qual regula o funcionamento dos estabelecimentos de ensino superior $^{16}$. Isso ocorreu no dia 20 de maio de 1941, "1200̣ da Independência e 530 da República”.

\section{A LUTA PELA AUTONOMIA}

Em 1943 manifestam-se claramente os esforços dispendidos por esse grupo de eminentes sanitaristas com vistas a conceder à Escola de Higiene e Saúde Pública situação de igualdade em termos das faculdades que então integravam a Universidade de São Paulo. Publica "O Estado de São Paulo, no dia 3 de março de 1943, discurso pronunciado pelo Conselheiro Marrey Júnior, no Departamento Administrativo de São Paulo, cujo Diretor era então Samuel Barnsley Pessoa ${ }^{(1)}$ :

... "Ponho, desde logo, em realce, o erro cometido pelos governos de, em regra, não entregarem a direção do serviço sanitário a higienistas e, de ordinário, colocarem até nos próprios laboratórios pessoas portadoras de diplomas, todas muito dignas mas quase sempre em jejum em matéria sanitária.

... O Brasil não seria o que é hoje se não fosse a obra de Oswaldo Cruz, no Rio de Janeiro, o saneamento do nordeste no governo Vargas, o trabalho de Emilio Ribas em Sāo Paulo, que há de prosseguir no governo Fernando Costa, com os conhecimentos técnicos do atual diretor do Departamento de Saúde e sob a orientação altruistica do ilustre Secretário da Saúde Pública. 
CANDEIAS, N. M. F. Memória histórica da Faculdade de Saúde Pública da Universidade de São Paulo 1918 - 1945. Rev. Saúde públ., S. Paulo, 18(n? esp.): 2-60, 1984.

Para isso, porém, Sr. Presidente, afigurou-se-me necessário não só o estudo de higiene que aos estudantes de medicina ministra o provecto Professor Paula Souza: é preciso que se especializem os brasileiros que pretendam exercer os cargos de saúde pública, isto $\dot{e}$, que se instituam cursos teoricos e práticos de sanitaristas, de engenheiros, de bacteriologistas, de enfermeiros e de educadores sanitdrios.

Alguns passos, em tal sentido, tem o Estado procurado dar. Em 1924, oficializou-se o Instituto de Higiene, que até entāo funcionava anexo à Faculdade de Medicina, subvencionado pela Fundação Rockefeller. Passou o Instituto de Higiene a realizar o curso de higiene daquele estabelecimento, os cursos de aperfeiçoamento para funcionários do Serviço Sanitário, de habilitação profissional para enfermeiras e visitadoras de saúde pública. Tentou-se, em 1931, a transformação do Instituto em Escola de Higiene e Saúde Priblica do Estado, na qual se faria o curso de Higiene da Faculdade de Medicina e se ensinariam as matérias básicas do curso de Saúde Pública. Em 1938, incorporou-se o Instituto à Universidade, já subordinado diretamente à cátedra de Higiene. Nele se estabeleceram certos serviços técnicos e um Centro de Aprendizado para determinado bairro da cidade. A escola de higiene - que a revolução idealizara, ficou no tinteiro.

Todavia, Sr. Presidente, à maneira do que se faz principalmente nos Estados Unidos, uma escola de higiene em São Paulo, em perfeita correlação com os institutos universitários de estudos politico-sociais, deverá estar forçosamente na cogitação dos que encaram o problema da higiene como coisa séria, como imperativo de são patriotismo $e$ não como simples passatempo. E se não estiver, que deste Departamento parta a sugestão, hoje principal objeto de minha vinda à tribuna".

O discurso do Conselheiro Marrey Júnior foi acompanhado por vários outros artigos a respeito: "A criação de uma Escola de Higiene destinada a formar profissionais especializados ("Folha da Manhâ", 7/3/1943); "Seria ato de justiça dar a Escola de Higiene situação igual à das Faculdades que integram a Universidade" ("Diário da Noite", 6/3/ 1943); "Associaça Paulista de Medicina Secção de Higiene e Moléstias Tropicais e Infetuosas" ("Correio Paulistano", 7/4/1943).

No dia 4 de março, portanto logo após a publicação pelo "O Estado de Sáo Paulo" do discurso proferido pelo Conselheiro Marrey Júnior, envia-lhe Paula Souza carta em que $\mathrm{diz}^{(1)}$ :

"A evolufão natural de suas atribuiçōes didáticas vem tornar patente a necessidade de dar à Escola de Higiene já existente maior desenvolvimento, colocando-a em paridade com as demais escolas universitárias, conforme V.Sa. tão bem compreendeu e defendeu no Conselho Administrativo - podendo-se mesmo até, conforme idéia expressa pelo Sr. Ministro da Educação, dar-lhe o título de Faculdade.

... O momento é assaz oportuno, encontrando-se à testa da Secretaria da Educação ilustre Professor Universitário e como Reitor também emérito Professor, ambos conorientes das necessidades do meio. $O$ mesmo se dá em relaçâa à Diretoria do Departamento de Saúde, cujo diretor é antigo colaborador do Instituto de Higiene e de onde saiu para a cátedra da Faculdade de Medicina": (1)

Pouco depois, no dia 13 de abril de 1943 , publica "A Gazeta" entrevista com o Diretor do Departamento de Saúde, Samuel Barnsley Pessoa, para quem a criação de uma Escola de Higiene de alto padrão, autônoma e integrada na Universidade, representava necessidade inadiável:

"Quando em principios do ano findo, o Professor Theotônio Monteiro de Barros Fi-

(1) Paula Souza refere-se a Theotônio Monteiro de Barros Filho, Secretário da Educação e Saúde Pública, no período de 3 de dezembro de 1942 a 12 de novembro de 1943, a Jorge Americano então Reitor da Universidade de São Paulo e a Samuel Barnsley Pessoa. 
CANDEIAS, N. M. F. Memória histórica da Faculdade de Saúde Pública da Universidade de São Paulo 1918 - 1945. Rev. Souide públ., S. Paulo, 18(no esp.): 2-60, 1984.

lho, eminente Secretário da Educação e Saúde Püblica honrou-me como convite para di. rigir o Departamento de Saude, manifestou em troca de idéias que então tivemos, sua conviç̧ão sobre a importância da formação de técnicos de Saúde Pública, por intermédio de uma Escola Superior, e a esse respeito nosso acordo foi absoluto.

... . - Acha que dispomos de elementos para instalar imediatamente semelhante escola?

- Sem duivida. O Estado ja conta, por exemplo, com um núcleo bastante aproveitável, em material e pessoal, representado peb Instituto de Higiene, atualmente anexo à Cadeira de Higiene da nossa Faculdade de Medicina, e onde já vêm sendo ministrados alguns cursos de especializacão em higiene...

- Pensa que a Escola de Higiene será organizada em breve?

- Acredito que sim. Há dias o ilustre Conselheiro Marrey Jünior, em luminosa oraçāo proferida no Departamento Administrativo, salientou a importância e necessidade da criação de uma Escola de Higiene. . . Mais recentemente, ainda, o Professor Jorge Americano, magnifico Reitor da nossa Universidade, em seu relatório anual, afizmou que a criação de tal Escola constitue um dos mais urgentes problemas de sua administraç̄̄o"...

Em 18 de abril, divulga a "Folha da Manhă" as palavras de Jorge Americano em Sessão Solene da Assembléia Universitária realizada na Faculdade de Direito:

"a atividade sanitária era julgada até há alguns decênios como função natural dos médicos. Todavia em face do progresso cientifico e social, tanto se alargou o âmbito das funçöes protetoras da saúde pública que, para sua execufão, são exigidos conhecimentos especiais.

... No médico clinico - prosseguiu - tal qual é o mesmo preparado nas faculdades médicas, predominam como é natural, os requisitos decorrentes de sua formafã̃o como médico.

Reconheceu-se, todavia, freqüentemente ndo bastarem esses conhecimentos para 0 exercicio da profissaio sanitária, exigindo-se do portador do diploma de médico estudos mais desenvolvidos e especiaes, afim de meIhor aparelhd-lo dquela funçuto. Tais estudos, alem de se aprofundarem em certos setores do terreno considerado puramente médico, ultrapassam estes, entrando pelas alcadas da sociologia, da engenharia e mesmo do direito.

... A elevacão do Instituto de Higiene, que é a Escola de Higiene e Saúde Pública do Estado à categoria de Faculdade de Higiene e Saúde Pública é, a nosso ver, medida das mais urgentes para a Universidade".

E justo afirmar que a Jorge Americano se deve realmente, como seria aliás reconhecido em reunião da primeira Congregação da $\mathrm{Fa}$ culdade de Higiene e Saúde Pública, a cria. ção da nova unidade autônoma da Universidade de São Paulo. A ele coube, por idealismo e devoção, a coordenação dos estudos que culminariam no Decreto-Lei 14.857 de julho de 1945.

Mas voltando d luta pela autonomia, al. guns meses depois do discurso de Jorge Americano, em 6 de janeiro de 1944, publica "O Estado de São Paulo" discurso do paraninfo Borges Vieira por ocasião da entrega dos diplomas da Escola de Higiene e Saude Publica:

"Fundado em 1918, pela ação conjunta da Faculdade de Medicina e da Fundaçāo Rockefeller, tendo, além do ensino da Higiene aos estudantes de Medicina, como uma de suas principais finalidades, preparar sanitaristas e auxiliares, veio ministrando cursos especializados para médicos, a princípio irregularmente, como o de 1921 e o de 1928, este com regulamento já baixado pelo Gover. no do Estado e, de 1938 para cá, regular-

Nota: Encontram-se no Arquivo da Pró-Memória da FSP/USP, estudos referentes ao projeto de lei para criação da Faculdade de Saúde Pública. Um deles foi elaborado por Benjamin Alves Ribeiro, em 1943, a pedido de Samuel B. Pessoa. 
CANDEIAS, N. M. F. Memória histórica da Faculdade de Saúde Pública da Universidade de São Paulo 1918 - 1945. Rev. Sauide públ., S. Paulo, 18 (n? esp.): 2-60, 1984.

mente, todos os anos, agora já com os diplomas reconhecidos pelo Governo Federal, ao lado dos destinados ao preparo de educado. res sanitários (1925) e nutricionistas (1940).

. . . Escola de Saúde Püblica do Estado, como já o denomina a lei, justo é efetivar sua elevação de instituição complementar da Universidade a Instituto Universitdrio, conforme tem estado na cogitação de nossas autoridades didaticas, encarmadas pelas figuras ilustres do nosso diretor e do magnifico rei. tor".

A tônica era portanto a mesma.

\section{A CRIAÇÃO DA FACULDADE DE SAUUDE PUBLICA}

Com o desencadear da segunda Guerra Mundial, praticamente se interromperam os trabalhos internacionais de saúde. Em 1944, entretanto, o que restara do antigo Serviço de Epidemiologia da Liga das Naçбes, foi transferido para outra organização, a "United Nations Relief and Rehabilitation Ad: ministration - UNRRA - agência criada nessa ocasião para tentar solucionar os graves problemas sanitários decorrentes daquele conflito ${ }^{1}$. A convite da nova organização, seguiu Paula Souza para Washington a fim de assumir o cargo de Chefe do Controle Epidêmico e, além disso, responder como Secretário da Comissão Internacional de Qua. rentena.

Várias cartas the foram enviadas por Borges Vieira, informando-o a respeito da evolução do projeto que propunha integrar a Escola de Higiene e Saúde Pública à Universidade de Sáo Paulo:

"Na última 3a feira o Instituto, quase em sua totalidade, foi pelo Magnifico Reitor levado d̀ presenca do Sr. Interventor (1) ${ }^{\text {, com }}$ o qual se congratulou pelo interesse que vem demonstrando pelo prosseguimento dos trimites. Falei em nome do Instituto e V. Exa, respondendo, disse esperar que tudo se fará bem. Foi uma feliz coincidência que a Secretaria da Justiça, à qual fiz referência em meiu speech, estava presente, e também me disse que verd com muito prazer a concretização da idéia". (28 de agosto de 1944)

"Sobre o caso da Faculdade de Higiene (2) nada hé a acrescentar d minha última carta. Já na Interventoria, para onde havia encaminhado o projeto o Dr. Jorge, voltou ao D.S. $P$. e at se encontra novamente. Irei em dia próximo, com o Dr. Jorge, ver o Reis, a respeito disso". (8 de setembro de 1944)

"Infelizmente, as noticias de agora nāo são aquelas que me alegraria comunicar. Depois de longa e nova via-sacra, chegamos a um novo ponto critico e desanimador. Como você sabe, voltou ao D.S.P. onde estacionou muito tempo e onde, ñ̃o obstante o modo de pensar do Ministro, sofreu algumas alterafōes, especialmente nos... (?)...... que mais nos interessam. $O$ Jorge arranjou uma fórmula, baseada no art. 110 de E.U., onde o seu caso ficava o mais satisfatoriamente posstvel resolvido. Por outro lado, permaneceria de pé o preenchimento das cátedras pelo 421, conforme a emenda Leitão da Cunha, apenas nao figuraria na lei a salvaguarda explicita para os 'atuais cronistas."'

(15 de novembro de 1944)

"Estava esperando para ver se poderia dar-Ihe noticias de maior progresso no andamento do projeto. A coisa continua muito lentamente. Após a critica do Dep. Serv. Pub., que você conhece, foi encaminhado pelo Jorge, que o fez acompanhar do parecer do Luciano. Voltou entretanto ñ̃o se sabe bem como, para o Reis que, após várias entrevistas conosco $e$ ouvir novamente suas seçōes de pessoal e organização, fez uns retoques justamente naqueles dois artigos mais criticos, assim como eliminou outros que pensa ser da alçada do regulamento. . .

(28 de dezembro de 1944)

(1) Borges Vieira refere-se a Jorge Americano e a Fernando Costa.

(2) Note-se que Borges Vieira refere-se à Faculdade de Higiene e não mais à Escola de Higiene e Saúde Pública. 
CANDEIAS, N. M. F. Memória histórica da Faculdade de Saúde Pública da Universidade de São Paulo 1918 - 1945. Rev. Sauide públ., S. Paulo, 18(n? esp.): 2-60, 1984.

A "longa via-sacra" referida por Borges Vieira levaria, finalmente, à incorporação da Escola à Universidade de São Paulo. Isto ocorreu mediante o Decreto-Lei 14.857, de 10 de julho de 1945, assinado pelo Interventor Federal em São Paulo, Fernando Costa. A Escola passou a denominar-se Faculdade de Higiene e Saúde Pública ${ }^{(1)}$, integrando-se assim aos demais estabelecimentos de nível superior como instituto universitário autô. nomo.

Tinham passado vinte e sete anos após a criação do Laboratório de Higiene da Faculdade de Medicina de São Paulo.

Faziam parte da Escola em julho desse ano: Geraldo Horácio de Paula Souza, Diretor, comissionado nos Estados Unidos desde 10 de junho de 1944; Primeiros Assistentes - Alexandre Wancolle, Benjamim Alves Rjbeiro, Francisco Borges Vieira, este Diretor em Exercício, Lucas de Assumpção, Pedro Egydio de Oliveira Carvalho e Paulo Cesar de Azevedo Antunes (posto à disposiçăo do Ministério da Educação); Segundos Assistentes - Francisco Antonio Cardoso, John La. ne, Rubens Azzi Leal e Rubens Tavares; Terceiros Assistentes - Dácio de Almeida Christovão (comissionado para fins de estudo nos Estados Unidos) e José Costa Sobrinho; Assistentes de Clínica - Alvaro Gujmarães Filho, Augusto de Sampaio Dória, João Alves Meira, José Gomes, Octavio Augusto Rodovalho, Pedro de Alcantara Machado, Raphael de Paula Souza, Roberto Dias Oliva e Vicente de Sampaio Lara; Assistente Odontológico - Alfredo Reis Viegas $^{(2)}$, Enfermeira - Iracema Niebler; Educadoras Sanitárias, Coraly Pimentel de
Mello, Helena Savastano, Louiset te Gimenes, Cynira Moreira Jardim e Lucia Jardim.

\section{PRIMEIRA REUNIÃO DA CONGREGAÇÃO}

"Aos dezesseis dias do mês de Julho de mil novecentos e quarenta e cinco, às 11,30 horas, realizou-se a Primeira Reunião da Congregação"(3). Pedindo a palavra Ålvaro Guimarães lembrou ter esta deveres a cumprir para com aqueles que organizaram e fundaram a Faculdade, solicitando a inclusão na Ata de um voto especial ao Magnifico Reitor, a Paula Souza e a Borges Vieira. Aprovados por aclamação os votos propostos, processou-se a eleição dos membros da Comissão que deveria elaborar o regulamento, tendo sido eleitos os professores Francisco Borges Vieira, Raphael de Paula Souza ${ }^{(4)}$ e Benjamim Alves Ribeiro, visto os Estatutos da Universidade determinarem que fossem os mesmos formulados pelas respectivas Congregaç⿸es. Para servir de padrão à nova Faculdade, selecionaram-se os regulamentos da Faculdade de Medicina e da Escola Politécnica, no que fosse aplicável, e no que fossem omissos os Estatutos Universitários. A seguir foram eleitos, como representantes da Congregação junto ao Conselho Universitário, Borges Vieira e, como suplen. te, Sampaio Lara.

Na segunda reunião da Congregação, dian. te do volume de trabalhos a serem executa. dos, foram eleitos, para integrar aquela $\mathrm{Co}$. missão, os professores Francisco Antonio Cardoso, Pedro Egydio de Carvalho e Paulo

(1) Atualmente Faculdade de Saúde Páblica.

(2) O Prof. Alfredo Reis Viegas, Professor-Titular, 6 atualmente Chefe do Departamento de Prática de Saúde Páblica e Presidente da Comissão de Pós-Graduação da FSP/USP.

(3) Livro de Atas da Congregação da Faculdade de Higiene e de Saúde Pública, vol. I, fl. 2 a 5. A Ata foi redigida por Maria Nogueira (Fajardo) que, por sua dedicagão a esta casa, merece aqui ser referida.

(4) O Prof. Raphael de Paula Souza, atualmente aposentado, é primo de Geraldo Horácio de Paula Souza. Conhecido internacionalmente, exerceu em 1946 o cargo de Diretor de Tuberculose e Saúde, tendo organizado a Campanha Nacional contra a Tuberculose, marco precursor dos programas de luta anti-tuberculose no Brasil. Foi catedrático de Tisiologia e Diretor da Escola de 1953 a 1956 e de 1961 a 1962. 
CANDEIAS, N. M. F. Memória histórica da Faculdade de Saúde Pública da Universidade de São Paulo 1918 - 1945. Rev. Saúde públ., S. Paulo, 18(no esp.): 2-60, 1984.

Cesar de Azevedo Antunes ${ }^{(1)}$. Na terceira procedeu-se à eleição da Comissão para estudo do Regulamento do Curso de Educadores Sanitários, tendo sido eleitos os professores Oliveira Carvalho, Sampaio Lara e Borges Vieira. Para os Curso de Nutricionistas, elegeram-se Francisco Antonio Cardoso, Alexandre Wancolle e Borges Vieira, expressando este a disposição de não fazer parte de duas comissões, tendo a Congregação elegido para substituí-lo, por aclamação, Benjamim Alves Ribeiro ${ }^{(2)}$.

Foi na nona reunião que Borges Vieira mostrou interesse em conhecer a opinião da casa a respeito da conveniência de se realizar, em sessão solene, a instalação da Faculdade. Concordando a Congregação com a sugestão de seu Diretor, deu-se início a discussóes referentes aos passos preliminares. Nessa mesma reunião, Borges Vieira referiu-se à necessidade de eleger um Conselho Técnico Administrativo provisório, esclarecendo que, embora na última sessão tivesse a casa resolvido ainda não elegê-lo por considerar que a própria Congregação funcionava como tal, parecia-lhe que no futuro surgiriam tantos assuntos a exigir pronta soluçăo, que se the afigurava indispensável delegar poderes à Comissão constituída por tres membros. Referiu-se então à necessidade de selecionar o timbre a ser utilizado nos diplomas que passariam agora a ser da competência da Faculdade, desejando que no próximo mês de dezembro já este os marcassem ${ }^{(3)}$.

\section{A INSTALAÇÃO DA FACULDADE DE SAUUDE PƯBLICA}

A instalação ocorreu em sessto magna da Congregação, na noite de 29 de novembro de 1945. Prestigiaram o ato com sua presença, o Interventor Federal, Embaixador Macedo
Soares, o Ministro da Educação, Raul Leitão da Cunha, o Diretor da Faculdade de Medicina e Reitor em exercício, Benedito Montenegro, o Secretário de Estado da Educação e Saúde, Antonio F. de Almeida Junior, o Di. retor da Escola Paulista de Medicina, Alvaro Guimarães, e altas autoridades civis, militares e eclesiásticas, bem como a primeira Congregação da Faculdade de Higiene e Saúde Pública naquela noite empossada ${ }^{13}, 15$.

Geraldo Horácio de Paula Souza encontrava-se ausente, razão pela qual foi a solenidade presidida pelo Diretor em exercício, Borges Vieira. Vale a pena mencionar, pelo muito que contribuíram è lutaram pela Saúde Pública, neste País, os ilustres nomes que integraram esta primeira Congregação: Geraldo Horácio de Paula Souza (Diretor), Francisco Borges Vieira (Diretor em Exercício), Paulo Egydio de Oliveira Carvalho, Lucas de Assumpção, Alexandre Wancolle, Francisco Antonio Cardoso*, Benjamim Alves Ribeiro, Paulo Cesar de Azevedo Antu. nes*, Raphael de Paula Souza*, José Maria Gomes, Âlvaro Guimarães Filho*, Pedro de Alcântara Marcondes Machado, João Alves Meira, Vicente de Sampaio Lara, Rubens Azzi Leal e John Lane.

Abrindo a sessáo e iniciando o ato da instalação do novo instituto de ensino superior da Universidade de São Paulo, fez uso da palavra o Prof. Benedito Montenegro e, em seguida, o Prof. Pedro de Alcân$\operatorname{tara}^{13}$ :

"A Congregação da Faculdade de Higiene e Saúde Pública de Säo Paulo delegou-me a incumbência - para mim muito honrosa de traçar as razões desta solenidade e sua significação. Ela constitui um momento festivo que marca, definitivamente, a transformação do antigo Instituto de Higiene de São

(1) Livro de Atas da Congregação da Faculdade de Saúde Pública, vol. I, fl. 7

(2) Livro de Atas da Congregação da Faculdade de Saúde Pública, vol. I, fl. 10

(3) Livro de Atas da Congregaçăo da Faculdade de Saúde Pública, vol. I, fl. 39 e 40.

* Foram Diretores da FSP/USP.

Nota: Tem sido inestimável, para o estudo da memória histórica da Faculdade de Saúde Pública, a contribuição dos professores aposentados, membros da Primeira Congregação da FSP - Alexandre Wancolle, Benjamim Alves Ribeiro, Joăo Alves Meira, Raphael de Paula Souza, , Rubens Azzi Leal e Vicente Sampaio Lara. 
CANDEIAS, N. M. F. Memória histórica da Faculdade de Saúde Pública da Universidade de São Paulo 1918 - 1945. Rev. Saúde públ., S. Paulo, 18 (no esp.): 2-60, 1984.

Paulo na sua feição agora certamente definitiva, porque atingiu o grau mais alto da hierarquia dos institutos que integram a Universidade.

... Efectivamente, desde a sua fundação em 1917, quando a Fundacão Rockefeller se prontificou a colaborar com o Governo do Estado na instalação da Cadeàra de Higiene na Faculdade de Medicina, ficou bem clara a necessidade de, em etapa ulterior, evoluir a cadeira, então organizada, para uma Faculdade de Higiene. A este Instituto seria dada, então, maior autonomia, para que pudesse ser convenientemente instruido e preparado o pessoal destinado aos trabalhos de saúde pública, composta não só de sanitaristas diplomados em Medicina, mas também de engenheiros sanitários, laboratoristas, nutricionistas, estaticistas e outros com diversa formação básica, todos, porém, com a necessária formação no ponto de vista funcional da saúde puiblica".

Reflete o texto, vale a pena repetir, o idealismo de um grupo de professores da Faculdade de Medicina que, arautos do futuro, vislumbraram na recém-criada Cadeira de Higiene, e em seu Laboratório de Higiene, o ponto de partida para criação de uma unidade autônoma e mais ampla da futura Universidade de São Paulo. Seriam estas as suas funções mais imediatas ${ }^{15}$ :

'realização de cursos de especializaçäo em Higiene e Saúde Pública para médicos, reconhecidos por Sua Excelência, o Senhor. Presidente da República, pelo Decreto no 7198 , de 20 de maio de 1941, com fundamento no Art. 23, do Decreto-Lei no 421, de 11 de maio de 1938; ministração de cursos para estudantes de Medicina, para educadores sanitários e para nutricionistas, regulamentados pelo Governo do Estado; imprescindibilidade legal da conclusão de tais cursos para o ingresso em cargos de médicos sanitaristas, educadores sanitários, etc".

A este respeito, envia Borges Vieira, carta dirigida a Paula Souza, então nos Estados Unidos, com data de 3 de dezembro de 1945:
"A Faculdade foi solenemente incorporada no dia 29 último, às 9 horas da noite. Veio do Rio, para presidir a cerimônia, o ministro Leitão da Cunha. Também esteve presente o interventor Macedo Soares. A presidencia de fato coube ao Montenegro, visto o Jorge, em vésperas de partir para os Estados Unidos, ja lhe ter antes passado a Reitoria. Mas o Jorge esteve presente e, com ele, numerosos professores de várias Faculdades. Todos de beca, inclusive o Macedo Soares. A festa esteve muito bonita. Falou em nome da Congregação o Pedro de Alcântara, e eu como diretor em exercicio. $O$ seu nome foi lembrado. Todos nós sentimos que Você não estivesse presente. $O$ Leitão veio do Rio expressa e unicamente para a cerimônia. .."

Haviam pois os dois colegas e amigos, assim como seus colaboradores, alcançado os objetivos que desde 1918 haviam persistentemente perseguido. O Decreto-Lei 14.857 consubstanciava os princípios preconizados por Welch e Rose, aqueles que, segundo estes, deveriam estruturar uma verdadeira Faculdade de Saúde Pública.

Terminara pois, de certa forma, a luta que jamais os abatera, mesmo nos momentos de maior e compreensível apreensão. Durante a revolução de 1930 quando tropas gaúchas ocuparam o prédio em construção. Quando desligados da Fundação Rockefeller temiam o não prosseguimento da obra iniciada por insuficiência ou corte de verbas. Quando a incompreensão de alguns, em posição de mando, tentara desalojá-los do espaço físico e funcional de uma unidade que ambos con. sideravam como um futuro instituto univer. sitário autônomo, visando a transformá.la, em Hospital das Clínicas, em quartel ou em mais um laboratório do Serviço Sanitário.

Já se disse que Geraldo Horácio de Paula Souza se encontrava ausente, não tendo comparecido, por isso, à instalação solene da Faculdade de Saúde Pública. A propósito, cumpre aqui intercalar um comentário de significativo valor para a Saúde Pública internacional e que muito honra esta Faculdade. 
CANDEIAS, N. M. F. Memória histórica da Faculdade de Saúde Publica da Universidade de São Paulo 1918 - 1945. Rev. Saride pribl., S. Paulo, 18(no esp.) : 2-60, 1984.

\section{A CRIAÇÃO DA ORGANIZAÇĀo MUNDIAL DA SAŨDE}

Se o Decreto-Lei 14.857 de 1945 marcara - término da longa luta que permitira a transformação do Laboratório de Higiene, criado em 1918, na almejada Faculdade de - Saúde Pública, unidade autônoma da Universidade de São Paulo, nem por isso deixaria Paula Souza de investir energias em outras propostas inovadoras.

Justamente no ano da criação da Faculdade de Higiene e Saúde Pablica fôra este designado pelo Governo Brasileiro para fazer parte de sua delegação na Conferência de São Francisco. Nessa ocasião submeteu à apreciação dos países participantes memorando sugerindo que problemas de saúde pública fossem incluídos na Carta das Naçōes Unidas. Mais tarde, apoiado pela Delegação Chinesa, iria propor reunião para estu. do da criação de uma agência internacional de saúde. Assim nasceu a Organização Mundial da Saúde.

Também amparada pela China, resultou a proposta na nomeação pelas Naçōes Unidas da Comissão que, em Paris, se responsabilizou pela elaboração do projeto a ser discutido pela Conferência Internacional de Saude. Esta reuniu-se em 1946. Paula Souza, autor da ideia, compareceu como delegado e vice-presidente. Uma vez aprovados os estatutos da Organização Mundial da Saúde, foi este nomeado membro da comissão interina dessa entidade e um de seus vice-presidentes. Durante toda a sua vida passou a representar o Brasil como delegado da agência por ele idealizada. Por sua valiosa atuação de interesse internacional, foi condecorado pelo Governo francês, recebendo a Ordem de Saúde Pública e, em seguida, a Legião de Honra. ${ }^{(1)}$

Vejamos como se expressou Paula Souza em entrevista concedida a Rádio Excelsior, no dia 26 de novembro de 1949:(1)

'Pergunta: Gostaria que o Prof. Geraldo Horácio de Paula Souza me dissesse alguma coisa sobre a Organizaçäo Mundial da Saúde. Como foi ela constitutda?

Resposta: Quando da Conferência das $\mathrm{Na}$ çōes Unidas, realizada em Săo Francisco, em 1945, a delegação brasileira, chefiada pelo saudoso ministro Leão Velloso, incluiu o nosso nome no seu quadro a fim de atendermos as questôes de ordem sanitária, porventura aventadas naquele certame. Do exame do projeto da Carta das Naf̧óes Unidas, elaborado na reuniāo de Dumbarton Oaks, no tamos que apesar do que se verificara relativamente à Liga das Nações, que sempre se distinguiu pelos trabalhos no campo da saúde pública, o referido projeto não co. gitava desse problema, a tal ponto que nem sequer continha os termos Saúde ou Higiene.

Pergunta: Qual teria sido o motivo dessa omissũo?

Resposta: De acordo com indagações que fizemos, não queriam os principais responsáveis por aquela nova iniciative se afastar da questão puramente de seguranga. Além disso, devido $\dot{a}$ insistência de grandes interesses em determinados patses, em relacato is várias organizaçōes sanitárias ja existentes, desejavam evitar qualquer embate nesse setor.

Pergunta: Como se explica então ter sido o problema cuidado na Conferência de Sta Francisco?

Resposta: Diante da exposiçāo que fizemos ao Ministro Leão Velloso, fomos autorizados, em nome da delegacão brasileira, a propor a inclusão na Carta de São Francisco da noçäo "Higiene e Saúde Prublica" nos arti. gos onde melhor se situassem tais conceitos, pois nem sequer o termo "saide" nela figurava. Após debates acalorados, vimos vito. riosa nossa proposta.

Pergunta: Essa providência, entretanto, não resolvia totalmente a questäo, não é exato?

Resposta: Realmente, em seguida propusemos fosse criada uma agência de saúde pú. blica internacional, dependente das Naçöes Unidas ou a elas filiada, que reunisse em um

(1) Arquivo da Pró-Memória, FSP, USP. 
CANDEIAS, N. M. F. Memória histórica da Faculdade de Saúde Pública da Universidade de São Paulo 1918 - 1945. Rev. Saúde públ., S. Paulo, 18(nO esp.): 2-60, 1984.

só organismo todas as demais que se encontravam esparsas, com finalidades parciais a elas afins. Essa medida foi a princtpio rejeitada e só depois de longas conversaçōes e ar. ranjos encontrou-se a fórmula a ser adotada em que o Brasil, aliando-se a uma das cinco grandes potencias, resolveu sugerir a criação de tal organismo. Essa sugestão, levada a plenário, foi unanimente aceita $e$, assim, $o$ Brasil e a China tornaram-se os patrocinadores oficiais da idéia.

Pergunta: Dai para diante o que sucedeu?

Resposta: Uma vez aceita a idéia, ela se consubstanciou; depois, com iniciativa do Conselho Econômico e Social, foi nomeada uma Comissão que elaborou projetos de estatutos para essa nova Organização. A aprovacão desses estatutos, em uma conferência internacional realizada em Nova York, deu origem à instalação da Organização Mundial da Saúde, que foi primeiramente regida por uma comissão interina e, desde que ratificados os estatutos pela maioria dos paises componentes das Nações Unidas, passou a ter vida legal e definitiva."

Homem de formação ecumênica, Paula Souza não recebera do Governo Brasileiro qualquer orientação dessa natureza.

Com o brilho que the era peculiar e com - vigor com que advogava grandes causas, le. vou a proposta às comissões da Conferência de São Francisco e, em seguida, à sessão plenária. Tinha sentido em seu espírito amadurecido e precursor a necessidade de criar um órgão internacional de saúde, da mesma forma que, vinte e sete anos antes, sentira também a necessidade de transformar o La. boratório de Higiene em unidade autônoma de ensino da Saúde Páblica.

Feitos estes comentários, voltemos à recém-criada Faculdade de Higiene e Saúde Pú. blica - "todos nós sentimos que Você não estivesse presente".

\section{O TIMBRE DA FACULDADE}

Consta no Livro de Atas do Conselho Técnico Administrativo da Faculdade de Higiene e Saúde Pública que, no dia 7 de março de 1946, às 10:30 horas, encontravam-se, na 1ạ Reunião Ordinária, os Professores eleitos e nomeados para membros do Conselho Técnico Administrativo por ato do Magnífico Reitor, nos termos do decreto-lei 15.549-A, Pedro Egydio de Oliveira Carvalho, Francisco Antonio Cardoso ${ }^{(1)}$ e João Alves Meira. Nessa ocasião tornou-se a mencionar, mais uma vez, a necessidade de definir o emblema da Faculdade de Saúde Pública, decidindo-se entregar a Alves Meira a responsabilidade desse estudo.

Autor de mais de 130 trabalhos, Alves Meira, atualmente aposentado, foi catedrá. tico de Diagnóstico de Doenças Transmissíveis da Faculdade de Saúde Pública e catedrático de Clínica de Doenças Tropicais e Infecciosas da Faculdade de Medicina da Universidade de São Paulo. Ocupou várias vezes o cargo de Vice-Diretor da Faculdade de Medicina, tendo sido seu Diretor no perfodo de 1963 a 1970. Foi também Vice- Diretor da Faculdade de Saúde Pública. Seu pai foi o eminente Prof. Domingos Rubião Alves Meira (1878-1946). Diretor da Faculdade de Medicina, em 1938, e Reitor da Universidade de São Paulo de junho de 1939 a junho de 1941. Seu filho, Domingos Alves Meira, é professor da Faculdade de Medicina da Universidade do Estado de São Paulo, em Botucatu. Há pois, nessa família, três geraçōes consecutivas de ilustres professores universitários.

Na 8 ạ sessão extraordinária do Conselho Técnico Administrativo, no dia 21 de junho de 1946, Alves Meira apresentou, à consideração de seus colegas, tres diferentes projetos, ficando a escolha definitiva para outra reunião. Nessa ocasião, os professores Pedro

(1) O Prof. Francisco Antonio Cardoso foi Secretário de Estado da Secretaria de Saúde Pública e da Assistência Social em 1951 e 1952 . Nessa ocasiâo reorganizou a antiga Diretoria Geral da Secretaria de Es. tado, transformando-a em Departamento de Administração 10 .

(2) A discussâo sobre o estudo do timbre da FSP encontram se nas folhas 5, 25, 26 e 36 do Livro de Atas do Conselho Técnico Administrativo, vol. I. 
CANDEIAS, N. M. F. Memória histórica da Faculdade de Saúde Pública da Universidade de São Paulo 1918 - 1945. Rev. Saúde públ., S. Paulo, 18 (no esp.): 2-60, 1984.

Egydio de Oliveira Carvalho e Antonio Francisco Cardoso ofereceram-se para colaborar no prosseguimento desse estudo.

$\mathrm{Na} 7$ ạ sessão ordinária, no dia 6 de setembro de 1946, após cuidadosa análise, aprovou-se o emblema da autoria de Paulo Lopes Leão, "obtido por gentil intermédio do Prof. Cardoso". (2) De acordo com prévia sugestão de Paula Souza, este destaca a deusa Higea, passando a marcar, de então para cá, os documentos desta Faculdade. E se o que se deseja é perpetuar a memória, parece-nos oportuno incluir aqui poema escrito por Maria Antonietta de Castro, aquela ilustre representante da primeira turma de Educadoras Sanitárias (1925).

Mas voltando à leitura do livro de Atas da nova Faculdade, visavam as discussōes dos primeiros meses a elaboração do Regulamento da Faculdade de Higiene e de Saúde Pública, o qual se concretizou com o Decreto-Lei No 15.549.A de 15 de janeiro de 1946.

\section{O JURAMENTO DOS SANITARISTAS}

Além do timbre, cuidou a Congregação de elaborar a formula do Juramento dos Sanitaristas, formados por esta Faculdade:

"Prometo Cumprir

Com Dignidade, Consciência

$E$ Probidade

Os Deveres do Profissional

De Saúde Pública

E Tudo Farei

Com Dedicação e Zelo

Pela Melhoria do Nivel de Sauide

Do Povo do Meu Pats".

Daqueles que passaram pela Faculdade de Saúde Pública da Universidade de Sáo Paulo, como docentes ou alunos, muitos se distinguiram pela significativa contribuição que deram e tèm dado à controvertida área da Saúde Pública. Foram ou são eméritos professores, pesquisadores, autores, direto- res, consultores, secretários e ministro da saúde, chefes de serviço, "fellows", bolsistas e memorialistas (1). Cumpriram com "Dignidade, Consciência e Probidade" o juramento dos Sanitaristas.

\section{UM ENCONTRO COM A HISTORIA}

Borges Vieira faleceu no dia 31 de agosto de 1950, aos 57 anos de idade, depois de prolongada doença. Assim se expressou Paula Souza em discurso proferido por ocasião da homenagem póstuma que lhe foi prestada no 30 o dia de seu falecimento ${ }^{(2)}$ :

". . Acariciou conosco a idéia de formafão desta casa, lutou pela realizaçāo de um ousado sonho da nossa mocidade, quando ainda quase todos do mesmo descriam earregimentavam-se em contrário os que dispunham do poder e dos meios.

Tendo a bondade como fundamento essencial de sua personalidade, Borges Vieira nunca, entretanto, permitiu que esse dom natural afrouxasse as normas da justiça. Mas sabia valer-se da bondade até mesmo na aplicacão da mais rigorosa medida que lhe impuzesse o sentimento do direito.

... Após dois anos de estudo intensivo que tivemos em comum nos Estados Unidos, animados pela idéia de fazermos da Cadeira de Higiene um Instituto capaz de se desenvolver, a seu tempo, em Escola de Higiene, não nos perdiamos em estéreis divagaçóes, mas procurávamos gradualmente os caminhos mais acertados para a consecucto do fim colimado. E quantos contratempos e di. ficuldades, sobretudo no inicio, se nos antepunham!

... Conseguiu, entretanto, ver o fruto do seu trabalho na evoluçāo das instituiçōes ds quais se dedicou: 0 ensino da higiene na Faculdade de Medicina, o preparo de médicos e engenheiros para os serviços especializados de saude puiblica, dos auxiliares indis-

(1) Cabe aqui referir o nome do Dr. José Antonio Alves dos Santos por sua contribuiçăo á memória histórica da Faculdade de Saúde Pública, USP.

(2) Arquivo da Pró-Memoria, FSP/USP. 
CANDEIAS, N. M. F. Memória histórica da Faculdade de Saúde Pública da Universidade de São Paulo 1918 - 1945. Rev. Saúde públ., S. Paulo, 18(nọ esp.): 2-60, 1984.

\section{HIGEA}

- Sou Higea -

de Aesculapius e Epione - a filha mais dileta, $e$, das colinas da Grécia,

cheias de sol, a rebentar em frutos,

- a eleita, a preferida.

A que a Serpente deu a beber, na taça da Experiência, o leite - Saber - e assim chegou à meta dos tesouros da ciência que conjura as doenças e rouba, à morte, a vida.

- Sou Higea - a deusa da Saúde, Vem, sobe comigo esta montanha, desde o vale, que jaz ao pé, todo impureza, ao cimo, onde tudo é claridade e luz.

Que eu tirarei da Natureza e darei, para teu gozo, a saciedade, o perfume dos lilazes e heliotropios, que o olfato agrada e o olhar prende e seduz. De par em par, teus olhos abrirei, como janelas, para manhãs sem nuvens, claras matinadas. As rosas da madrugada, as mais frescas, mais viçosas e mais belas, transfundirei em teu sangue, que te darão vida - a Vida é plenitude.

- Sou Higea -

- Vou, por toda a parte, onde me chamam. Do lodo das sargetas, que transmudo na beleza de campinas, de flores esmaltadas. Transformo as cousas todas, tudo, ao toque mágico e encantado da minha sábia varinha de condão. Bato na choça humilde, nạ palhoça sem ar, sem bimbalhar de risos, sem limpeza e luz, e penduro manchas de sol pelas paredes e a tapecaria rica, de pensamentos sāos; e abro janelas, rasgo portas e cortinas, por onde mando entrar a claridade, a flux.

\section{- Sou Higea -}

Dai-me o barulho louco da cidade, que anda por ai a se expandir, atoz, que eu te darei sons de ouro, de harmonia infinda, embaladora e doce, embriagadora e linda, que te darão repouso e mente calma e nervos sāos, e uma vida sossegada e boa e paz no coraçäo.

- Sou Higea -

- Dai-me a entranha das Mães, que é sacrossanta, que sobre ela a desdobrarei meu manto imaculado 
CANDEIAS, N. M. F. Memória histórica da Faculdade de Saúde Páblica da Universidade de São Paulo 1918 - 1945. Rev. Saude públ., S. Paulo, 18(no esp.): 2-60, 1984.

cheia de amor e, com ternura tanta

e proteção,

que banirei do mistério do Nascer, puro e sagrado,

- a escuridão -

para que só veja a luz do dia, triunfante,

a Criança - plena de robustez, de vida, exuberante.

- Dai-me a Infância, fraca, doente, desgrafada

que, para sempre e longe, alijarei seu fardo de desgraças, de trabalho e dor,

elhe darei a força aos músculos e a cor da rosa às faces,

vivacidade e ardor.

- Sou Higea -

Dai-me os Jovens e Donzelas,

a louca mocidade,

e eu transformarei seus desejos, seus anseios,

em um caminho cheio

de pensamentos bons, de calma castidade.

- Dai-me, Pais aflitos, Mães chorosas, para os quais o sol da alegria estó a se pôr. que eu transformarei seu sofrimento

e farei de seus jardins desertos da alegria

(de que as rosas se foram, num momento)

- reinos de Felicidade e Amor.

- Vem comigo,

Vem me ajudar.

Não me deixes, magoada e entristecida, chorando e a clamar

por multidōes perdidas, transviadas,

que deixaram, de vez, conselhos sábios, ensinamentos bons.

Ajuda-me a lutar

contra a temivel Doenga e contra a Morte.

Ajuda-me a reconquistar,

através de minha Ciência, de meus Dons,

vassalos, para meu Reino Forte.

- Desespero, Desgraça e Dor - longe, bem longe.

Higea - de Aesculapius e Epione, feliz rebento,

Higea chegou.

Vida - toma o lugar da Dor e Sofrimento.

Saúde - ressurge, da morte, a Luz, o condenado.

Sorriso - volta, de novo, aos lábios descorados.

Higea, espera,

Irei contigo.

Farei de ti meu Ideal, a minha Estrela, o meu Bordão.

Irei contigo.

Plantarei em cada vida uma Esperança,

em cada alma desolada, a Primavera,

em cada Homem, cada Mulher, cada Criança,

um novo CORAÇÃO. 
CANDEIAS, N. M. F. Memória histórica da Faculdade de Satide Pública da Universidade de São Paulo 1918 - 1945. Rev. Soúde públ., S. Paulo, 18(no esp.): 2-60, 1984.

pensáveis a essas tarefas, dentre os quais devemos destacar, por terem surgido especialmente nesta casa, os educadores sanitários, os Centros de Saude e o tempo integral.

... Se podemos afirmar que parte de sua vida é parte da nossa, por isso fomos inseparáveis na realização do ideal que nos dominou no já longtnquo 1920 , não menos verdade é que se integrando com a Instituição como o fez, toda ela compartilha da mesma forte emoção que sentimos."

De fato, a vida de Borges Vieira representava importante parte da vida de Paula Souza, que pouco sobreviveu à perda de seu grande e dedicado amigo. Morreu poucos meses depois, no dia 2 de maio de 1951, aos 61 anos de idade. Como o pai faleceu no cumprimento de seus deveres. Antonio Francisco, fundador da Escola Politécnica, morreu aos 74 anos, organizando aula que deveria ministrar nesse mesmo dia; Geraldo Horácio faleceu na véspera de viagem ligada à Organização Mundial da Saúde. Numerosas cartas de pêsames foram enviadas à Sra. D. Evangelina Rodrigues de Paula Souza, sua esposa, duas das quais convêm aqui registrar por seu inestimável valor histórico ${ }^{(1)}$ :

\section{Prezada Senhora Paula Souza}

Acabo de saber, com grande pesar, da morte de Geraldo. Eu o considerava meu amigo pessoal e não posso aceitar a idéia de que tenha morrido.

Era um homem de grande capacidade e de grandes realizaçōes. Seu preparo científico, sua imensa dedicação ao trabalho, seu belo idealismo, seu carater integro e seu profundo patriotismo, tornaram-no uma das grandes figuras da Saúde Pública do mundo. Sentiremos imensamente a sua falta.

Wilson G. Smillie

\section{Prezada Senhora Souza}

A Assembléia Mundial da Saúde abriu esta manha e o Presidente referiu-se expressivamente à grande contribuiçāo do Dr. Paula Souza para a organização internacional da saúde.

O nome de seu esposo, na verdade, entrará na história como o principal fundador da Organização Mundial da Saúde. Como muitos outros de seus colegas, sinto-me orgulhoso de ter-me associado a ele neste trabalho. Para mim pessoalmente sua morte é uma grande perda, pois - como a senhora sabe ele foi meu amigo intimo e colega de longa data.. .

Szeming Sze $e^{(2)}$

Assim partiu Geraldo Horácio "cavaleiro andante dos mais altos ideais" (3) para seu merecido encontro com a História. Há quem afirme que se um indivíduo não tivesse existido, outro certamente teria realizado sua obra. Há quem acredite que a História não se prende a homens mas a circunstâncias. Não é este o presente caso.

$O$ depoimento de sua vida que neste relato se fundamentou em documentos que pertencem ao acervo da Faculdade de Saúde.Pú. blica ou foram cedidos, para este fim, por sua família, seus colegas e amigos, parece realmente indicar que a história da Saúde Pública em nosso meio não teria sido a mesma se Paula Souza não tivesse existido. Haja em vista o fato de que esta Escola representa, ainda hoje, a única Faculdade Universitária de Saúde Pública neste país.

Algumas condições foram certamente necessárias para desencadear o processo que, de 1918 a 1945, permitiu transformar o Laboratório de Higiene em instituto autônomo da Universidade de São Paulo. A existência de um ilustre sanitarista e homem público com

(1) As cartas em fac-simile encontram-se no Arq. Fac. Hig. S. Paulo, 17, 1963.

(2) Da Delegação Chinesa à Conferência das Naçōes Unidas, São Francisco, 1945, membro da Comissão Interina da OMS; representante das Naçōes Unidas à 1ạ Assembléia Mundial da Saúde, Genebra, 1948.

(3) Palavras do Prof. Benjamim Alves Ribeiro, na oração proferida em homenagem ao Prof. Geraldo Horácio de Paula Souza no dia 2 de maio de 1958, aniversário de sua morte. 
CANDEIAS, N. M. F. Memória historica da Faculdade de Saúde Pŕblica da Universidade de São Paulo 1918 - 1945. Rev, Saúde públ., S. Paulo, 18(no esp.) : 2-60, 1984.

vocação de comando, que sabia exatamente onde queria chegar e, a seu lado, técnicos competentes e disciplinados.

"Senhoras e Senhores

Vivem por estas salas e paredes e mais nos nossos coraçōes, a lembranca destes dois amigos que foram o exemplo vivo da honradez e do patriotismo a serviço do povo de nossa terra.

Foram eles os fautores primordiais de tudo que acabo de vos dizer"."

\section{REFERENCIAS BIBLIOGRAFICAS}

1. BRAGA, E. A saúde pública no plano internacional. Arq. Fac. Hig. S Paulo, 2:53-66, 1959.

2. CAMPOS, E. de S. História da Universidade de São Paulo. São Paulo, Saraiva Livreiros Editores, 1954.

3. CANDEIAS, N.M.F. Forças propulsoras e restritivas na área da Educação em Saúde Pública. In : AÇÃO participativa: perspectivas de atuação dos educadores de saúde pública. Brasília, DF, Centro de Documentação do Ministério da Saúde, 1984.p. 39-44.

4. GALVĀo, A.L. Ayrosa. Faculdade de Higiene e Saúde Pública: sua evoluçắo e seu papel no desenvolvimento da saúde pública no Brasil. Arq. Fac. Hig. S. Paulo, 13: 1$11,1959$.

5. HUME, J.C. The Johns Hopkins School of Hygiene and Public Health In: Bowers, J. Z. \& Purcell, E. F., eds. Schools of Public Health: present and future. New York, Josiah Macy Jr., 1974. p. 60-9.

6. LACAZ, C. da S. Vultos da medicine brasileira. São Paulo, Ed. Helicon, 1963 v. 1.

7. LEGISLAÇÃO Federal do Ensino Superior, 1825-1925. São Paulo, Reitoria da Universidade de São Paulo, 1953.

8. MASCARENHAS, R. dos S. Contribuição para o estudo da administração estadual em São Paulo. São Paulo, 1949. (Tese de Livre-Docência - Faculdade de Higiene e Saúde Pública da USP)
9. MASCARENHAS, R. dos S. \& FREITAS, A.V. de. Contribuição ao estudo da história do ensino de Educação Sanitária na Faculdade de Higiene e Saúde Pública da Universidade de São Paulo. Arq. Fac. Hig. S. Paulo, 13: 243-62, 1959.

10. MASCARENHAS, R. dos S. História da saúde pública no Estado de São Paulo. Rev. Saúde públ., S. Paulo, 7:433-46, 1973.

11. NEVES, C. de S. Ensino superior no Brasil: legislą̧ão e jurisprudência federais Rio de Janeiro, Ministério da Educação e Cultura/ Instituto Nacional de Estudos Pedagógi$\cos , 1955$.

12. ROSEN, R. A history of public health. New York, MD Publications, 1958.

13. SANTOS, P. da S. Cinquientenário da Faculdade de Saúde Pública da USP. Rev. Saude públ., S. Paulo, 9:95-7, 1975.

14. UNIVERSIDADE DE SĀO PAULO. Faculdade de Medicina. Memoria histórica da Fa. culdade de Medicina. São Paulo, 1938.

15. UNIVERSIDADE DE SÃO PAULO. Instalação solene da Faculdade de Higiene e Saúde Pública. Sáo Paulo, Imprensa Oficial do Estado, 1946.

16. VIEIRA, F.B. Preservação da saúde no decorrer dos tempos. Arq. Fac. Hig. S. Paulo, 2: 3-18, 1948. 